\title{
Fracture prediction in primary care : more than bone alone
}

Citation for published version (APA):

van Geel, A. C. M. (2008). Fracture prediction in primary care : more than bone alone. [Doctoral Thesis, Maastricht University]. Datawyse / Universitaire Pers Maastricht. https://doi.org/10.26481/dis.20081010ag

Document status and date:

Published: 01/01/2008

DOI:

10.26481/dis.20081010ag

Document Version:

Publisher's PDF, also known as Version of record

\section{Please check the document version of this publication:}

- A submitted manuscript is the version of the article upon submission and before peer-review. There can be important differences between the submitted version and the official published version of record.

People interested in the research are advised to contact the author for the final version of the publication, or visit the DOI to the publisher's website.

- The final author version and the galley proof are versions of the publication after peer review.

- The final published version features the final layout of the paper including the volume, issue and page numbers.

Link to publication

\footnotetext{
General rights rights.

- You may freely distribute the URL identifying the publication in the public portal. please follow below link for the End User Agreement:

www.umlib.nl/taverne-license

Take down policy

If you believe that this document breaches copyright please contact us at:

repository@maastrichtuniversity.nl

providing details and we will investigate your claim.
}

Copyright and moral rights for the publications made accessible in the public portal are retained by the authors and/or other copyright owners and it is a condition of accessing publications that users recognise and abide by the legal requirements associated with these

- Users may download and print one copy of any publication from the public portal for the purpose of private study or research.

- You may not further distribute the material or use it for any profit-making activity or commercial gain

If the publication is distributed under the terms of Article $25 \mathrm{fa}$ of the Dutch Copyright Act, indicated by the "Taverne" license above, 
Fracture prediction in primary care:

more than bone alone 
C) A.C.M. van Geel, Maastricht 2008

ISBN: 9789052787534

Cover: Ad van Geel | Artstudiovangeel

Production: Datawyse | Universitaire Pers Maastricht

The studies presented in this dissertation were conducted under the auspices of the School for Public Health and Primary Care (Caphri) at the Department of General Practice, Maastricht University, the Netherlands.

Printing of this dissertation was financially supported by the Dutch Arthritis Association. 


\title{
Fracture prediction in primary care: more than bone alone
}

\author{
Proefschrift \\ ter verkrijging van de graad van doctor \\ aan de Universiteit Maastricht, \\ op gezag van de Rector Magnificus, Prof. mr. G.P.M.F. Mols, \\ volgens het besluit van het College van Decanen, \\ in het openbaar te verdedigen \\ op vrijdag 10 oktober 2008 om 14.00 uur \\ door \\ Antonia Catharina Maria van Geel \\ geboren te Eersel
}

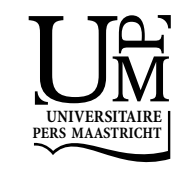


Promotores:

Prof. dr. G.J. Dinant

Prof. dr. P.P. Geusens

Copromotor:

Dr. D.J.M. van der Voort

Beoordelingscommissie:

Prof. dr. G.I.J.M. Kempen, voorzitter

Dr. P.J.M. Elders (VU Medisch Centrum Amsterdam)

Prof. dr. C.P. van Schayck

Prof. dr. G.H.I.M. Walenkamp 
I Keep six honest-serving men

(They taught me all I knew)

Their names are What and Why and When

and How and Where and Who

Rudyard Kipling

Just So Stories for Little Children

The Elephant's Child (1902, London) 



\section{Contents}

Chapter 1 General introduction 8

Chapter 2 Timing and risk factors for clinical fractures among postmenopausal women: a 5-year prospective study

Chapter 3 Risk factors for clinical fractures among postmenopausal women: a 10-year prospective study

Chapter 4 Clinical fractures cluster in time in women from menopause onwards

Chapter 5 Bone- and fall-related fracture risks in women and men with a recent clinical fracture

Chapter 6 Measures of bioavailable serum testosterone and estradiol and their relationships with muscle mass, muscle strength and bone mineral density in postmenopausal women:

a cross-sectional study

Chapter 7 General discussion

Chapter 8 Summary

Chapter 9 Samenvatting

Dankwoord

About the author 136

List of publications 


\section{Chapter 1}

\section{General introduction}




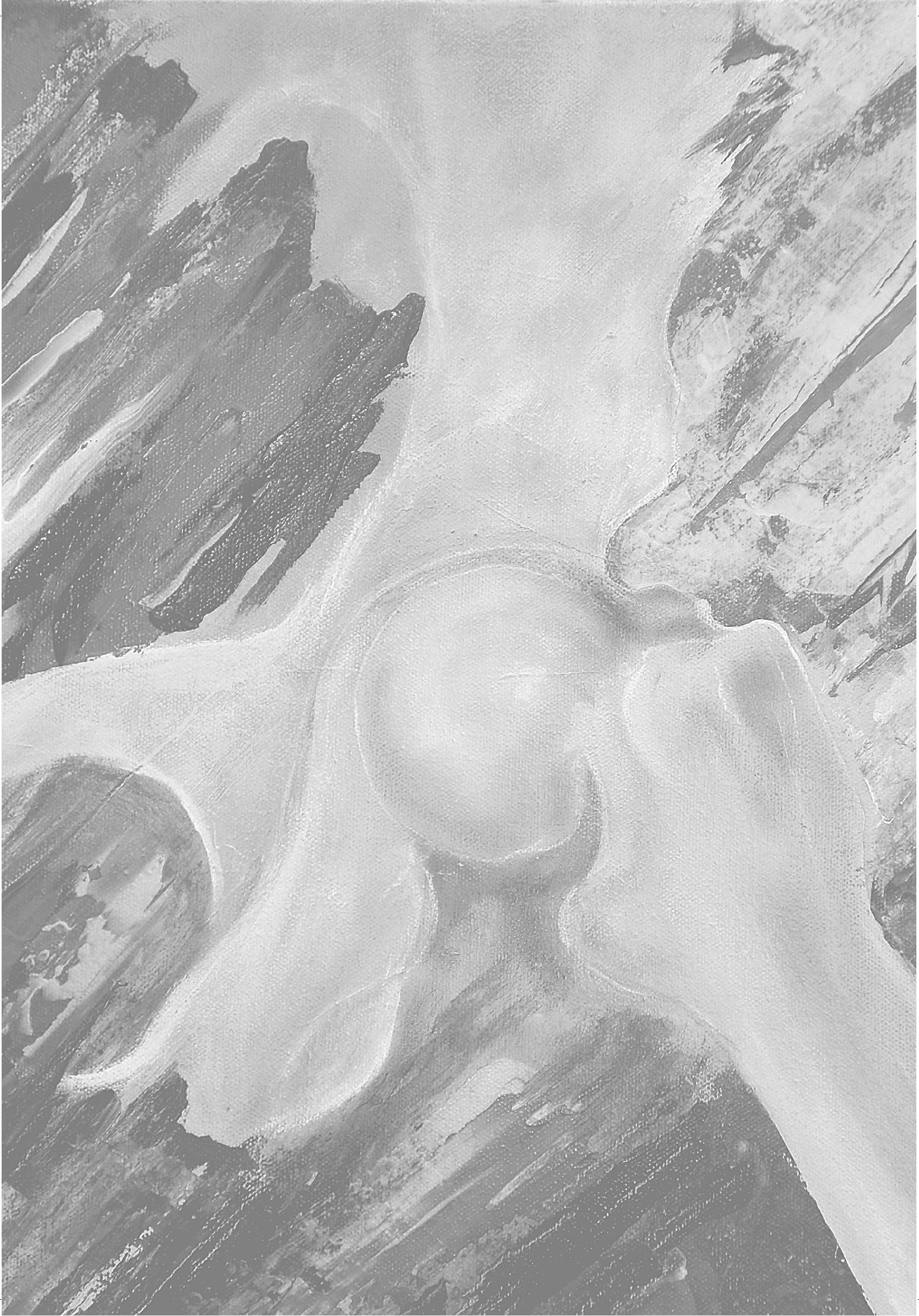


10 Chapter 1 


\section{General Introduction}

T n Homer's Illiad, Aeneas, Aphrodite's mortal son, is struck on the hip by a huge rock. The blow tears the skin, snaps the tendons and crushes the bone. This Homeric description (800 B.C.) probably refers to a case of a hip fracture caused by the same mechanism used in experimental studies by Pearson 2800 years later. ${ }^{1-4}$ Before Homer, the ancient Egyptians (approximately 1600 B.C.) had already written down their knowledge of medicine, when papyrus became available. Since the Egyptians preserved their dead, large numbers of skeletons have been found. In a study of 6000 skeletons, 1 in 32 showed a fracture, $31 \%$ of which were forearm fractures and $12 \%$ hip or femur fractures. ${ }^{4,5}$

Fractures are a growing problem today. It is estimated that 1 in 2 women aged 50 years will sustain a fracture during their remaining lifetime. ${ }^{6}$ In 2000 , the number of osteoporotic fractures in Europe alone was estimated at 3.8 million. The direct costs were estimated at $€ 36.2$ billion, and these are expected to increase to $€ 76.7$ billion by the year 2050 , based on the expected demographic changes. $^{7}$ In view of this high economic burden and the fracture-related morbidity and mortality, it is important to identify patients who are at high risk for fractures and for whom interventions to prevent fractures would be most effective.

The aim of this research project was to determine the prognostic determinants of fractures in postmenopausal women in a population-based cohort of 4203 women between 50 and 80 years, who were prospectively followed in 12 general practices over a period of 10 years. A wide variety of risk factors were taken into account, such as clinical risks (including lifestyle), bone mineral density (BMD), muscle strength, biochemical markers of bone turnover and endogenous circulating sex hormones. During the study it became clear that the time that elapses between first (initial) and subsequent clinical vertebral and non-vertebral fractures was a critical factor: once a fracture has occurred, the risk of a subsequent fracture is higher at short-term than at long-term.

This dissertation describes the development of clinical algorithms, which can be used in daily practice to quickly and accurately detect those postmenopausal women at highest risk of fracture. This introductory chapter starts with a general description of healthy bone, osteoporosis and clinical fractures. This is followed by an overview of risk factors for fractures, according to the World Health Organisation (WHO). It ends by explaining the research questions and the study design used in the project, and with an outline of the dissertation. 


\section{Healthy Bone}

Cortical bone forms the external surface of bone, while trabecular bone is located towards the metaphysis and epiphysis and in the vertebrae. The most common bone cells are osteoblasts, osteoclasts, osteocytes and lining cells. After the end of growth, when peak bone mineral density (BMD) has been achieved, bone deposition and resorption are in equilibrium, and the total bone mass and BMD remain constant.

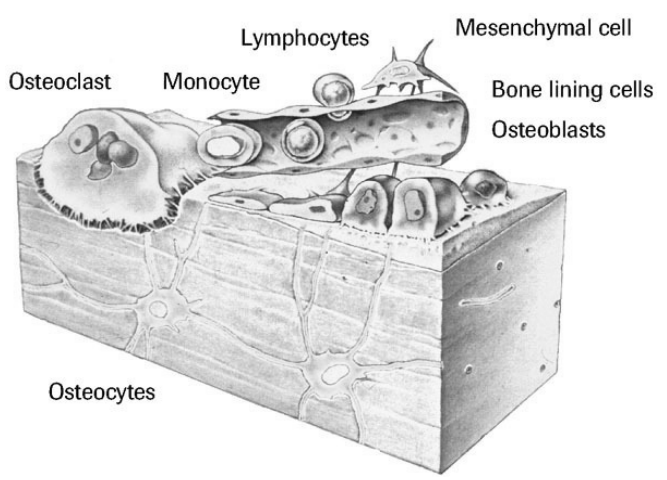

Osteoblasts continually deposit bone matrix. They are on the outer surfaces of the bones and in the bone cavities. Some of the osteoblasts become embedded in bone as osteocytes, while others become lining cells that cover bone surfaces. Bone is continually resorbed by osteoclasts followed by immediate deposition of new bone, so bone is continuously in turnover. This process is tightly controlled in terms of location, time and balance and occurs at one to two million microscopic sites, the so-called basic metabolic units. Bone turnover has several functions. First, it adjusts bone to the load applied to it, e.g. in that bones thicken when subjected to heavy loads and bone is lost when not loaded. Thus, normal bone turnover contributes to the maintenance of bone's resistance to fracture. Second, bone turnover replaces old bone when microfractures or fractures occur. The intraosseous location of osteocytes and the extensive network of connections by canaliculi that allows communication among osteocytes and between them and osteoblasts, mean that the osteocytes play a key role in the translation of mechanical signals into changes in bone deposition and resorption. Third, bone turnover contributes to calcium homeostasis, as bone is the major reservoir for the calcium that becomes available by bone resorption when exogenous calcium is deficient, such as with deficient calcium intake and vitamin $\mathrm{D}$ deficiency. 8,9

It is estimated that five to ten percent of the skeleton is renewed every year. In adults, the osteoblasts are normally active on approximately four percent and osteoclasts on less than one percent of all surfaces, but the activity of remodelling is five to ten times higher in trabecular than in cortical bone. This implies that trabecular bone is fully renewed every seven years and cortical bone every 13 to 15 years. The cellular activities underlying bone turnover are 
the result of complex communications between cells by cytokines, growth factors and hormones. 8

\section{Osteoporosis}

Osteoporosis is derived from the Greek words osteon (bone) and poros (opening or hole), and therefore, it literally means holes in the bone. In this disorder, the bone resorption outpaces the deposition. It occurs most often in postmenopausal women, due to deficiencies in estrogen, calcium and vitamin D and other factors related to aging. ${ }^{8,9}$ The World Health Organisation (WHO) has defined osteoporosis as 'a disease characterised by low bone mass and microarchitectural deterioration of bone tissue, leading to enhanced bone fragility and a consequent increase in fracture risk. ${ }^{, 10}$ Bone mass and bone mineral density (BMD) are most commonly measured by dual energy X-ray absorptiometry (DXA), a validated technique for measuring BMD in the lumbar spine and proximal femur. The outcome of the

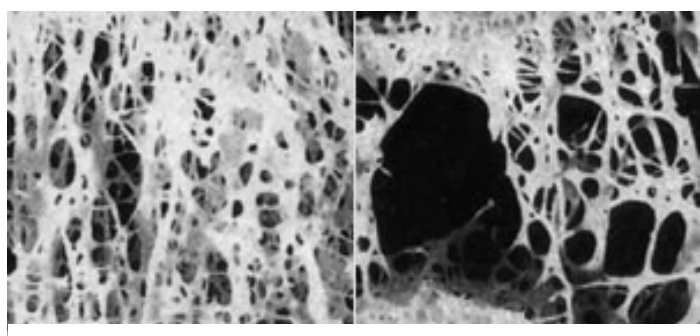

Normal bone

Osteoporotic bone

DXA-measurement is expressed as a T-score. The cut-off points for osteoporosis is a T-score of 2.5 standard deviations (SDs) below the mean BMD, at the spine or at the hip, in a healthy female population aged 30 years, because the fracture rate in this reference population is very low ( $T$-score = (measured BMD - young adult BMD) / young adult SD). ${ }^{7,10-12}$ Approximately 15 to $20 \%$ of all postmenopausal women are defined as osteoporotic, using the diagnostic threshold of a T-score $\leq-2.5$ and measured with DXA at the femoral neck (FN) or lumbar spine. ${ }^{13}$ In addition, a Z-score compares the BMD of a patient with the mean BMD of healthy persons matched for age, gender, and ethnic-origin (Z-score = (measured BMD - age-matched BMD) / age-matched SD). However, most patients presenting with a clinical vertebral or non-vertebral fracture have no osteoporosis according to the above definition of the WHO. ${ }^{14}$ Thus, other components than BMD are involved in bone's resistance to fracture, such as bone turnover, clinical bone- and fall-related risks, which contribute to fracture risk independently of BMD.

While BMD is a marker of what happened in the past, biochemical bone markers provide information about the current turnover in the bone. ${ }^{15,16}$ Some 
bone markers reflect the enzymatic activity of osteoblasts and osteoclasts, others the degradation products released into blood and urine during bone turnover. ${ }^{17,}{ }^{18}$ The levels of bone markers are related to fracture risk, independent of BMD. ${ }^{19-21}$

\section{Fractures}

The clinical significance of osteoporosis is based on the occurrence of fractures. Women have more fractures than men, because they have a lower peak BMD, hypogonadism (menopause) is universal in postmenopausal women, women develop more structural bone loss than men and women live longer. ${ }^{22-25}$

Hip fractures increase morbidity and mortality and entail enormous socioeconomic costs. ${ }^{7,12,22}$ Estimates show that, in Europe alone, 890000 persons (79.9\% women) sustained a hip fracture $(23.5 \%$ of total number of fractures) in the year 2000 (Table 1). The number of hip fractures alone could increase to 6.3 million by the year 2050 or even to 8.2 million if the assumption is made that the age-related incidence of hip fractures will increase over the years. The mortality rate from hip fractures, mostly caused by co-morbidity, varies between 10 and $30 \%$. Of those who survive their fracture, half have persistent disability. ${ }^{7}$ 22, 26, 27 In Europe alone, the direct medical costs for hip fractures are estimated at $€ 24.4$ billion (67.2\% of total medical costs for fractures).

Table 1 Number and direct costs of osteoporotic fractures in Europe.

\begin{tabular}{|c|c|c|c|c|}
\hline & \multicolumn{4}{|c|}{ Fracture site } \\
\hline & Hip & Spine & Other & Total \\
\hline \multicolumn{5}{|l|}{ Number of fractures $(000)$} \\
\hline Men & 179 & 163 & 712 & 1054 \\
\hline Women & 711 & 406 & 1622 & 2739 \\
\hline Men and women & 890 & 569 & 2334 & 3793 \\
\hline \multicolumn{5}{|l|}{ Costs of fractures $(€ 000000)$} \\
\hline Men & 4556 & 198 & 4003 & 8757 \\
\hline Women & 19796 & 521 & 7173 & 27490 \\
\hline Men and women & 24352 & 719 & 11176 & 36247 \\
\hline
\end{tabular}

Adapted from Kanis et al. (2005) ${ }^{7}$

Radiographic vertebral fractures are the most common fractures at a population level among postmenopausal women. Although, only 1 in 3 come to clinical attention, all are associated with increased morbidity, mortality and fracture risk and thus indicate bone failure, independent of BMD. ${ }^{28}$ The most frequent fractures in postmenopausal women presenting with a fracture are non- 
vertebral, non-hip fractures, ${ }^{29}$ and these entail the second highest cost of fractures (Table 1). A study among 262 men and women at the Maastricht University Medical Centre (MUMC) found that the most frequent types of fracture occurring within two years after the first fracture were those of the hip $(22.1 \%)$, clinical vertebral $(16.0 \%)$, and non-vertebral fractures $(61.9 \%){ }^{29}$

Numbers of fractures are increasing, due to the ageing of the population and increased lifespan. Since the proportion of elderly people in Europe will increase by $33 \%$ over the next 25 years, fractures will impose even greater claims on health care planning. Therefore, guidelines on osteoporosis all advocate clinical case-finding to identify those groups of patients at high risk in whom interventions to prevent fractures have been shown to be most effective. $^{30}$

\section{Risk Factors for Fractures}

Increasing age and low BMD are major risk factors for fractures and DXA measurements are necessary to confirm the presence of osteoporosis in terms of BMD. However, there are many other skeletal factors than BMD that contribute to bone fragility, as well as numerous extra-skeletal factors that are related to fracture risk, both independent of BMD. ${ }^{12,31-36}$

In the Netherlands, the guideline on osteoporosis of the Dutch College of General Practitioners (DCGP-guideline) is recommended to be used in general practice. ${ }^{37}$ However, this guideline focuses on risk factors for osteoporosis rather than fractures. The World Health Organisation (WHO) ${ }^{11}$ and the Dutch guideline on osteoporosis $(\mathrm{CBO})^{31}$ have developed algorithms for fracture risk prediction. The recently released FRAX ${ }^{\mathrm{TM}}$ algorithm of the $\mathrm{WHO}$ is based on the same risk factors as the Dutch guideline on osteoporosis, plus additional risk factors. The FRAX includes the following risk factors: (1) age, (2) a history of fractures, ${ }^{12,29,30,35,38-52}(3)$ a parenteral history of hip fracture, ${ }^{12,30,35,50,53-56}(4)$ low body weight or body mass index (BMI), ${ }^{12}, 30,45,57,58$ (5) use of glucocorticosteroids, ${ }^{12,30,59-64}(6)$ rheumatoid arthritis (RA), ${ }^{9}, 12,30$ (7) current cigarette smoking, ${ }^{12,30,45,65}$ (8) excessive alcohol intake (intake of three units or more daily), and (9) secondary osteoporosis. ${ }^{12,30,66}$ The WHO algorithm can be used for calculating the 10-years fracture risk in individual patients, with and without including levels of BMD.

The WHO algorithm and the Dutch guideline on osteoporosis do not include risk factors for falling, since there is some doubt whether the risk identified would be modified by a pharmaceutical intervention. ${ }^{67}$ However, it has been found that 
several fall-related risk factors ${ }^{68-77}$ are predictors of fractures, independent of BMD and other clinical risks, as has been shown for hip fractures. ${ }^{78}$ Although fall prevention measures prevent falls, no data indicate that they also prevent fractures. The clinical consequences of recognising fracture risks are: (1) it contributes to refine fracture risk prediction and (2) it gives the opportunity to start focused or multifaceted fall prevention strategies.

\section{Research Questions}

The research questions in this dissertation concern bone and extra-skeletal risk factors for fractures:

1. What are the risk factors for a first or subsequent clinical fracture in postmenopausal women during long-term follow-up?

2. As it became clear during the study that fractures cluster in time, the question was raised what the time relation is between a first and subsequent fracture in postmenopausal women.

3. What is the prevalence of bone- and fall-related risk factors in patients presenting with a first fracture?

4. What is the relation between age-related changes in muscle mass, muscle strength and age-related changes in endogenous circulating sex hormones in postmenopausal women?

\section{Study Design}

The design of this research project is a population-based cohort study. The baseline study was conducted between 1992 and 1994. Five years later, a random sample of participants of the baseline study was selected to participate in a follow-up study and ten years after baseline, all traceable and surviving women from the baseline study were invited to participate in the second followup study.

\section{Baseline study}

Between October 1992 and March 1994, a cross-sectional population-based study was performed among 4203 postmenopausal women aged 50 to 80 years (Figure 1). The region can best be described as consisting of two cities in the southern part of the Netherlands, with surrounded suburban villages. Twentythree general practitioners (GPs) participated in this study. The assessment 
started with BMD, weight and height measurements. A questionnaire enquired about possible risk factors for osteoporosis. Calcium intake was measured using a validated questionnaire. This baseline study resulted in a dissertation about the detection of patients with osteoporosis and risk factors for osteoporosis in daily general practice in a cross-sectional study design. ${ }^{34,35,79}$

\section{Five-year follow-up study}

Five years after baseline (1998-2000), all 703 non-healthy women, who were included in the statistical analysis in the baseline study, were selected for participation in a 5-year follow-up study. All 703 women were invited to participate, in order to minimise selection bias due to the limited number of nonhealthy postmenopausal women in the baseline study (e.g. clinically significant rheumatologic disease (including rheumatoid arthritis), use of glucocorticosteroids, and chronic alcoholism during 12 months prior to the study). In addition, a random sample of 983 of the 3500 healthy women (Figure 1) was drawn (based on $\left.(5303 / 3804)^{*} 703\right)$. The cohort of this study thus consisted of 1686 postmenopausal women. One GP refused to participate, and some women were deceased or untraceable, resulting in 1207 women being invited to participate in this 5-year follow-up study. Non-participation by some invited women meant that the eventual statistical analysis was based on data of 759 women, who all signed an informed consent form (Figure 1). All women underwent BMD measurements of the lumbar spine (L2-L4) and the femoral neck (FN) by DXA, and an assessment of possible clinical risk factors for osteoporosis and fractures (e.g. weight, height, family history, medical history, and diet) as well as laboratory tests (blood- and urine samples).

Approximately half of the 759 women were randomly selected, for a more extensively assessment, which involved muscle strength and balance tests. In the end, 329 postmenopausal women were included in the statistical analysis, involving muscle strength and balance tests plus laboratory values (Figure 1).

\section{Ten-year follow-up study}

Approximately ten years after the baseline study (2002-2004), all women who had participated in the baseline study, minus those who were deceased or untraceable at the time of the 5-year study, were selected for the ten-year follow-up study (Figure 1). In total, 2847 women were invited to participate in this study. Since some of the invited women refused to participate, the eventual statistical analysis included data of 2372 women, who all signed an informed consent form (Figure 1). All women completed a questionnaire about fracture history and medical history. 


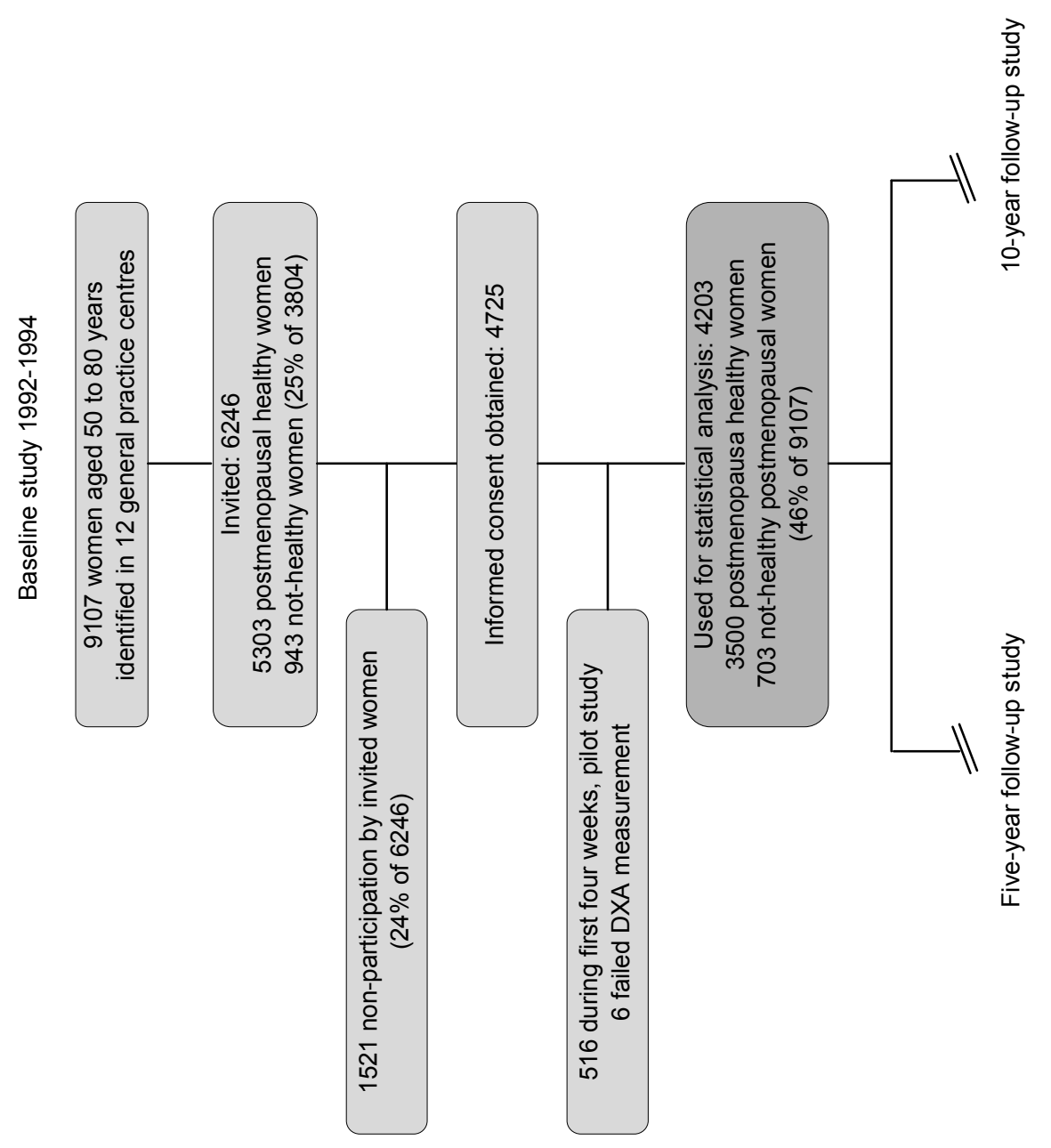




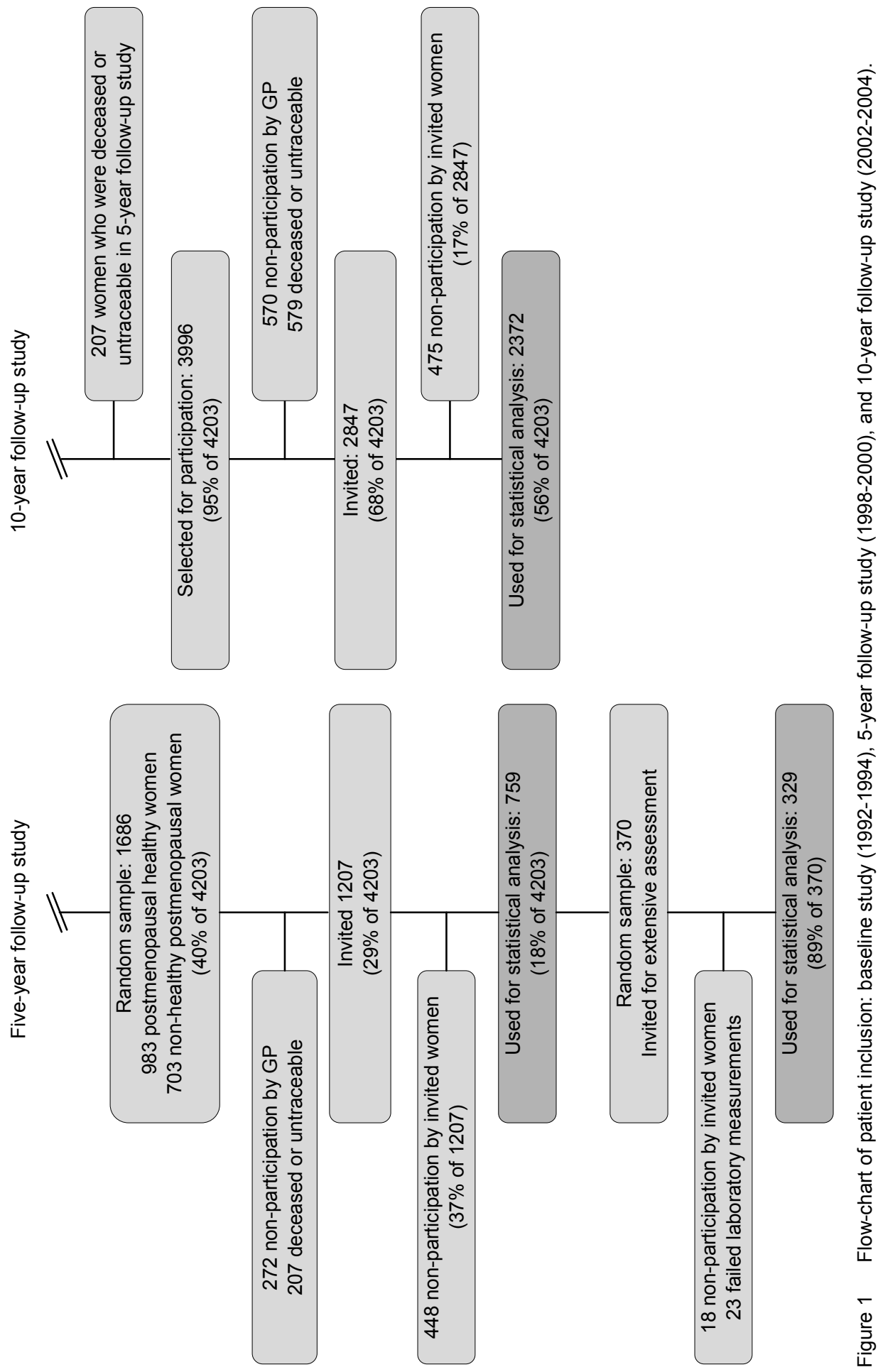




\section{Outline of this Dissertation}

Chapters 2 and 3 describe the construction of two clinical algorithms, using the data of the 5- and 10-year follow-up studies, which focuses on the bone-related risk factors for clinical fractures in postmenopausal women (research question 1). Since the time relation between a first and subsequent fracture seemed to play a role in the re-fracture rate, this relation was investigated, and the results are presented in chapter 4 (research question 2).

The prevalence of bone- and fall-related risk factors was investigated in patients with an initial fracture, and this prevalence is described in chapter 5 (research question 3).

The relation between age-related loss in muscle strength and muscle mass in postmenopausal women in relation to sex hormones is described in chapter 6 (research question 4).

Chapter 7 presents a general discussion of the studies reported on in this dissertation, as well as the methodology and recommendations for daily practice and future research. 


\section{References}

1. Gremk MD. Diseases in the ancient Greek world. 1991, Baltimore: The Johns Hopkins University Press.

2. Homerus. Illias. 2002, Amsterdam: Athenaeum-Polak \& Van Gennep.

3. Pearson JR, Hargadon EJ. Fractures of the pelvis involving the floor of the acetabulum. $J$ Bone Joint Surg Br 1962; 44(b): 550-61.

4. Prevezas N. Evolution of pelvic and acetabular surgery from ancient to modern times. Injury 2007; 38(4): 397-409.

5. Salib P. Orthopaedic and traumatic lesions in ancient Egyptians. J Bone Joint Surg Br 1962; 44(b): 944-7.

6. Staa van TP, Dennison EM, Leufkens HG, et al. Epidemiology of fractures in England and Wales. Bone 2001; 29(6): 517-22.

7. Kanis JA, Johnell O. Requirements for DXA for the management of osteoporosis in Europe. Osteoporos Int 2005; 16(3): 229-38.

8. Guyton AC, Hall JE. Textbook of medical physiology. Tenth ed. 2000, Philadelphia: W.B. Saunders Company.

9. Marieb EN. Human Anatomy \& Physiology. Fifth ed. 2001, San Fransisco, Boston, New York: Benjamin Cummings. An imprint of Addison Wesley Longman. Inc.

10. World Health Organisation WHO. Prevention and Management of Osteoporosis. Report of a WHO Scientific Group WHO Technical Report Series 2003; No 921.

11. Kanis JA, Burlet $\mathrm{N}$, Cooper $\mathrm{C}$, et al. European guidance for the diagnosis and management of osteoporosis in postmenopausal women. Osteoporos Int 2008; 19: 399-428.

12. Keen R. Osteoporosis: strategies for prevention and management. Best Pract Res Clin Rheumatol 2007; 21(1): 109-22.

13. Kanis JA, Gluer CC. An update on the diagnosis and assessment of osteoporosis with densitometry. Committee of Scientific Advisors, International Osteoporosis Foundation. Osteoporos Int 2000; 11(3): 192-202.

14. Khosla S, Melton LJ, 3rd. Clinical practice. Osteopenia. N Engl J Med 2007; 356(22): 2293300.

15. Kim BJ, Yu YM, Kim EN, et al. Relationship between serum hsCRP concentration and biochemical bone turnover markers in healthy pre- and postmenopausal women. Clin Endocrinol (Oxf) 2007; 67(1): 152-8.

16. Vankrieken L, Luthart K. Laboratory Support in the Management of Menopause and Osteoporosis. 2001; Available from: http://diagnostics.siemens.com/siemens/en_GLOBAL/ gg_diag_FBAs/files/news_views/tech_reports_pdfs/ZB206-A.pdf. DPC Technical Report.

17. Delmas PD. Biochemical markers of bone turnover. I: Theoretical considerations and clinical use in osteoporosis. American journal of medicine 1993; 95(5a): 11s-6s.

18. Garnero P, Delmas PD. Bone markers. Baillieres Clin Rheumatol 1997; 11(3): 517-37.

19. Chapurlat RD, Garnero P, Breart G, et al. Serum type I collagen breakdown product (serum CTX) predicts hip fracture risk in elderly women: the EPIDOS study. Bone 2000; 27(2): 283-6.

20. Garnero P, Delmas PD. New developments in biochemical markers for osteoporosis. Calcif Tissue Int 1996; 59 Suppl 1: S2-9.

21. Garnero P, Hausherr E, Chapuy MC, et al. Markers of bone resorption predict hip fracture in elderly women: the EPIDOS Prospective Study. J Bone Miner Res 1996; 11(10): 1531-8.

22. Delmas PD, Fraser M. Strong bones in later life: luxury or necessity? Bull World Health Organ 1999; 77(5): 416-22. 
23. Cummings SR, Kelsey JL, Nevitt MC, et al. Epidemiology of osteoporosis and osteoporotic fractures. Epidemiol Rev 1985; 7: 178-208.

24. Schuit SCE, Klift van der M, Weel AEAM, et al. Fracture incidence and association with bone mineral density in elderly men and women: the Rotterdam Study. Bone 2004; 34: 195-202.

25. Woolf AD, Akesson K. Preventing fractures in elderly people. BMJ 2003; 327(7406): 89-95.

26. Browner WS, Pressman AR, Nevitt MC, et al. Mortality following fractures in older women. The study of osteoporotic fractures. Arch Intern Med 1996; 156(14): 1521-5.

27. Keene GS, Parker MJ,Pryor GA. Mortality and morbidity after hip fractures. BMJ 1993; 307(6914): 1248-50.

28. Cooper C, Atkinson EJ, O'Fallon WM, et al. Incidence of clinically diagnosed vertebral fractures: a population-based study in Rochester, Minnesota, 1985-1989. J Bone Miner Res 1992; 7(2): 221-7.

29. Helden van $\mathrm{S}$, Cals $\mathrm{J}$, Kessels $\mathrm{F}$, et al. Risk of new clinical fractures within 2 years following a fracture. Osteoporos Int 2006; 17(3): 348-54.

30. Kanis JA, Borgstrom F, De Laet C, et al. Assessment of fracture risk. Osteoporos Int 2005; 16(6): 581-9.

31. Kwaliteitsinstituut voor de Gezondheidszorg CBO. Osteoporose Tweede Herziene Richtlijn. 2002, Alphen aan de Rijn: Van Zuiden Communications BV.

32. Hamblen D. Who cares for the patient with a fragility fracture? Orthop Today Internat 2004; 7.

33. Riggs BL, Melton III LJ. The worldwide problem of osteoporosis: insights afforded by epidemiology. Bone 1995; 17(5): 505-11S.

34. Voort van der DJM, Dinant GJ, Rinkens PELM, et al. Construction of an algorithm for quick detection of patients with low bone mineral density and its applicability in daily general practice. J Clin Epidemiol 2000; 53: 1095-103.

35. Voort van der DJM, Geusens PP, Dinant GJ. Risk factors for osteoporosis related to their outcome: fractures. Osteoporos Int 2001; 12: 630-8.

36. Voort van der DJM, Weijer van der PHM, Barentsen R. Early menopause: Increased fracture risk at older age. Osteoporos Int 2003; 14: 525-30.

37. Elders PJM, Leusink GL, Graafmans WC, et al. NHG-Standaard Osteoporose. Huisarts en Wetenschap 2005; 48(11): 559-70.

38. Gunnes M, Mellström D,Johnell O. How well can a previous fracture indicate a new fracture? A questionnaire study of 29,802 postmenopausal women. Acta Orthop Scand. 1998; 69(5): 50812.

39. Klotzbuecher CM, Ross PD, Landsman PB, et al. Patients with prior fractures have an increased risk of future fractures: a summary of the literature and statistical synthesis. J Bone Miner Res 2000; 15(4): 721-7.

40. Ross PD, Genant HK, Davis JW, et al. Prediciting vertebral fracture incidence from prevalent fractures and bone density amon non-black, osteoporotic women. Osteoporos Int 1993; 3(3): 120-6.

41. Kanis JA, Johnell $\mathrm{O}$, De Laet $\mathrm{C}$, et al. A meta-analysis of previous fracture and subsequent fracture risk. Bone 2004; 35(2): 375-82.

42. Klift van der M, Laet de $\mathrm{C}$,Pols $\mathrm{H}$. Assessment of fracture risk: Who should be treated for osteoporosis? Best Pract Res Clin Rheumatol 2005; 19(6): 937-50.

43. Lindsay RL, Silverman SL, Cooper $\mathrm{C}$, et al. Risk of new vertebral fracture in the year following a fracture. JAMA 2001; 285(3): 320-3.

44. Johnell $\mathrm{O}$, Kanis JA, Oden A, et al. Fracture risk following an osteoporotic fracture. Osteoporos Int 2004; 15(3): 175-9. 
45. Cummings SR, Nevitt MC, Browner WS, et al. Risk factors for hip fracture in white women. N Engl J Med 1995; 332(12): 767-73.

46. McGrother CW, Donaldson MM, Clayton D, et al. Evaluation of a hip fracture risk score for assessing elderly women: the Melton Osteoporotic Fracture (MOF) study. Osteoporos Int 2002; 13(1): 89-96.

47. Center JR, Bliuc D, Nguyen TV, et al. Risk of subsequent fracture after low-trauma fracture in men and women. JAMA 2007; 297(4): 387-94.

48. Nguyen ND, Pongchaiyakul C, Center JR, et al. Identification of high-risk individuals for hip fracture: a 14-year prospective study. J Bone Miner Res 2005; 20(11): 1921-8.

49. Black DM, Steinbuch M, Palermo L, et al. An assessment tool for predicting fracture risk in postmenopausal women. Osteoporos Int 2001; 12(7): 519-28.

50. Siris ES, Miller PD, Barrett-Connor E, et al. Identification and fracture outcomes of undiagnosed low bone mineral density in postmenopausal women: results from the National Osteoporosis Risk Assessment. JAMA 2001; 286(22): 2815-22.

51. Nevitt MC, Cummings SR, Stone $\mathrm{KL}$, et al. Risk factors for a first-incident radiographic vertebral fracture in women $>$ or $=65$ years of age: the study of osteoporotic fractures. J Bone Miner Res 2005; 20(1): 131-40.

52. Miller PD, Barlas S, Brenneman SK, et al. An approach to identifying osteopenic women at increased short-term risk of fracture. Arch Intern Med 2004; 164(10): 1113-20.

53. Bauer DC, Browner WS, Cauley JA, et al. Factors associated with appendicular bone mass in older women. The Study of Osteoporotic Fractures Research Group. Ann Intern Med 1993; 118(9): 657-65.

54. Keen RW, Hart DJ, Arden NK, et al. Family history of appendicular fracture and risk of osteoporosis: a population-based study. Osteoporos int 1999; 10(2): 161-6.

55. Fox KM, Cummings SR, Powell Threets K, et al. Family history and risk of osteoporotic fracture. Study of Osteoporotic Fractures Research Group. Osteoporos int 1998; 8(6): 557-62.

56. Kanis JA, Johansson $\mathrm{H}$, Oden $\mathrm{A}$, et al. A family history of fracture and fracture risk: a metaanalysis. Bone 2004; 35(5): 1029-37.

57. Kato I, Toniolo P, Zeleniuch Jacquotte A, et al. Diet, smoking and anthropometric indices and postmenopausal bone fractures: a prospective study. Int J Epidemiol 2000; 29(1): 85-92.

58. Laet de C, Kanis JA, Oden A, et al. Body mass index as a predictor of fracture risk: A metaanalysis. Osteoporos int 2005; 16(11): 1330-8.

59. Aron DC, Findling JW,Tyrrell JB, Glucocorticods \& Adernal Androgens, in Greenspan's Basic \& Clinical Endocrinology, Gardner D.G. and Shoback D., Editors. 2007, The McGraw-Hill Companies, Inc.: New York.

60. Staa van TP, Abenhaim L, Cooper C, et al. Public health impact of adverse bone effects of oral corticosteroids. Br J Clin Pharmacol 2001; 51(6): 601-7.

61. Staa van TP, Leufkens HG, Abenhaim L, et al. Use of oral corticosteroids and risk of fractures. J Bone Miner Res 2000; 15(6): 993-1000.

62. Staa van TP, Leufkens HG, Abenhaim L, et al. Oral corticosteroids and fracture risk: relationship to daily and cumulative doses. Rheumatology (Oxf) 2000; 39(12): 1383-9.

63. Staa van TP, Leufkens HG, Cooper C. The epidemiology of corticosteroid-induced osteoporosis: a meta-analysis. Osteoporos Int 2002; 13(10): 777-87.

64. Staa van TP, Leufkens HG, Cooper C. Utility of medical and drug history in fracture risk prediction among men and women. Bone 2002; 31(4): 508-14.

65. Law MR, Hackshaw AK. A meta-analysis of cigarette smoking, bone mineral density and risk of hip fracture: recognition of a major effect. BMJ 1997; 315(7112): 841-6. 
66. Kanis $\mathrm{JA}$, Johansson $\mathrm{H}$, Johnell $\mathrm{O}$, et al. Alcohol intake as a risk factor for fracture. Osteoporos Int 2005; 16(7): 737-42.

67. World Health Organisation WHO. WHO Scientific Group on the assessment of osteoporosis at primary health care level 2007; Available from: http://www.who.int/chp/topics/Osteoporosis.pdf.

68. O'Loughlin JL, Robitaille $\mathrm{Y}$, Boivin JF, et al. Incidence of and risk factors for falls and injurious falls among the community-dwelling elderly. Am J Epidemiol 1993; 137(3): 342-54.

69. Blake AJ, Morgan K, Bendall MJ, et al. Falls by elderly people at home: prevalence and associated factors. Age Ageing 1988; 17(6): 365-72.

70. Tinetti ME, Speechley M,Ginter SF. Risk factors for falls among elderly persons living in the community. N Engl J Med 1988; 319(26): 1701-7.

71. Tinetti ME, Williams CS. Falls, injuries due to falls, and the risk of admission to a nursing home. N Engl J Med 1997; 337(18): 1279-84.

72. Campbell AJ, Borrie MJ, Spears GF, et al. Circumstances and consequences of falls experienced by a community population 70 years and over during a prospective study. Age Ageing 1990; 19(2): 136-41.

73. Roudsari BS, Ebel BE, Corso PS, et al. The acute medical care costs of fall-related injuries among the U.S. older adults. Injury 2005; 36(11): 1316-22.

74. Schwab M, Roder F, Aleker T, et al. Psychotropic drug use, falls and hip fracture in the elderly. Aging (Milano) 2000; 12(3): 234-9.

75. DeGoede KM, Ashton Miller JA,Schultz AB. Fall-related upper body injuries in the older adult: a review of the biomechanical issues. J Biomech 2003; 36(7): 1043-53.

76. Laet de CE, Pols HA. Fractures in the elderly: epidemiology and demography. Baillieres Best Pract Res Clin Endocrinol Metab 2000; 14(2): 171-9.

77. Tinetti ME. Clinical practice. Preventing falls in elderly persons. N Engl J Med 2003; 348(1): 42-9.

78. Cummings SR, Nevitt MC, Browner WS, et al. Risk factors for hip fracture in white women. Study of Osteoporotic Fractures Research Group. N Engl J Med 1995; 332(12): 767-73.

79. Voort van der DJM, Brandon S, Dinant GJ, et al. Screening for Osteoporosis Using Easily Obtainable Biometrical Data: Diagnostic Accuracy of Measured, Self-Reported and Recalled BMI, and Related Costs of Bone Mineral Denisty Measurements. Osteoporos Int 2000; 11: 233-9. 


\section{Chapter 2}

\section{Timing and risk factors for clinical fractures among postmenopausal women: a 5-year prospective study}

Tineke van Geel, Piet Geusens, Ivo Nagtzaam, Cyril Schreurs,

Danny van der Voort, Paula Rinkens, Arnold Kester and Geert-Jan Dinant

BMC Med 2006; 4 (24). doi: 10.1186/1741-7015-4-24 


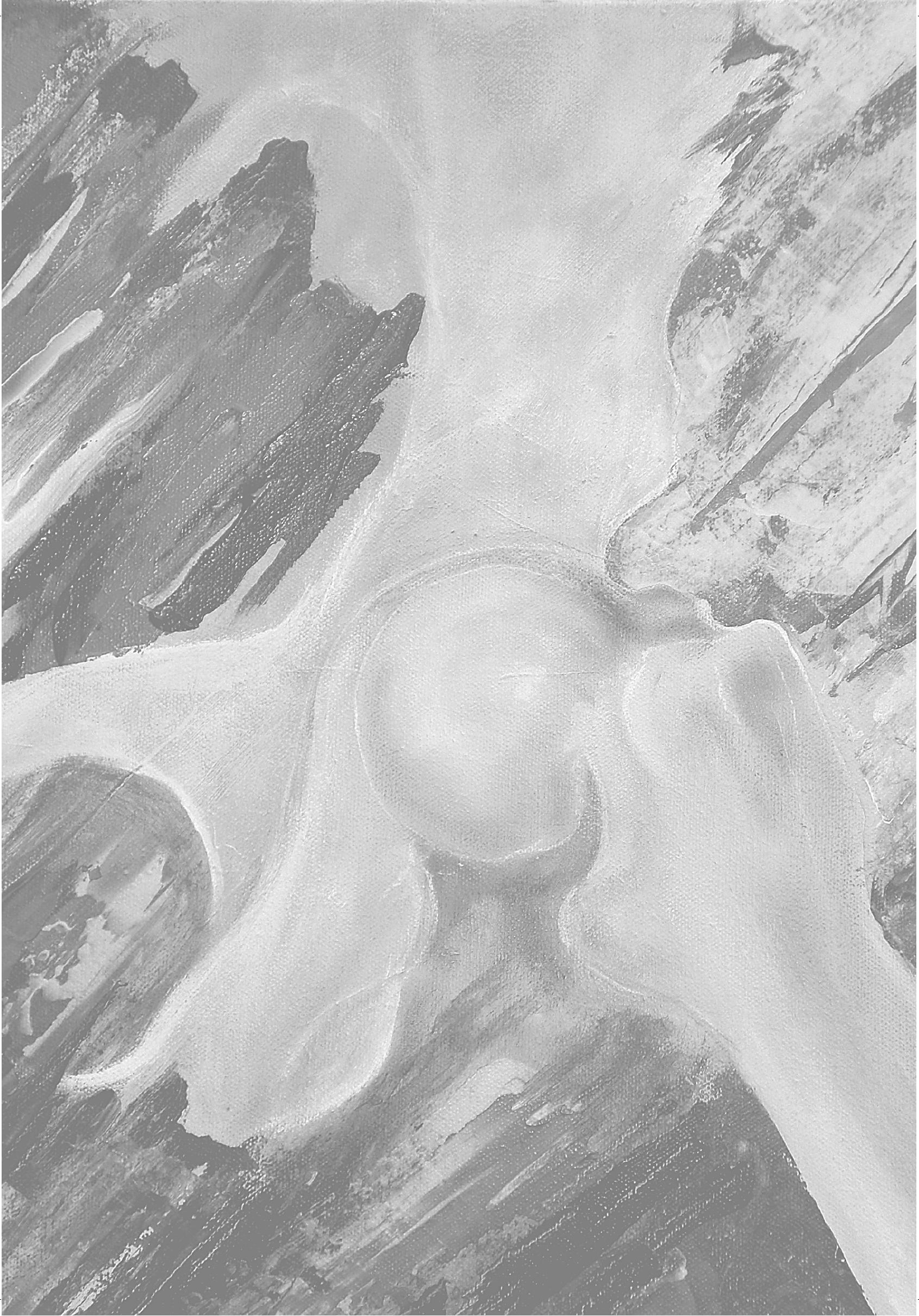




\section{Abstract}

\section{Introduction}

Many risk factors for fractures have been documented, including low bone mineral density (BMD) and a history of fractures. However, little is known about the short-term absolute risk (AR) of fractures and the timing of clinical fractures. Therefore, we assessed the risk and timing of incident clinical fractures, expressed as 5-year AR, in postmenopausal women.

\section{Methods}

In total, 10 general practice centres participated in this population-based prospective study. Five years after a baseline assessment, which included clinical risk factor evaluation and BMD measurement, 759 postmenopausal women aged between 50 and 80 years, were re-examined, including undergoing an evaluation of clinical fractures after menopause. Risk factors for incident fractures at baseline that were significant in univariate analyses were included in a multivariate Cox survival regression analysis. The significant determinants were used to construct algorithms.

\section{Results}

In the total group, $12.5 \%$ (95\% confidence interval (Cl): 10.1-14.9) of the women experienced a new clinical fracture. A previous clinical fracture after menopause and a low BMD ( $\mathrm{T}$-score $\leq-1.0$ ) were retained as significant predictors with significant interaction. Women with a recent previous fracture (during the past 5 years) had an AR of $50.1 \%$ (Cl: $42.0-58.1$ ) versus $21.2 \%(\mathrm{Cl}$ : 20.7-21.6) if the previous fracture had occurred earlier. In women without a fracture history, the AR was $13.8 \%(\mathrm{Cl}: 10.9-16.6)$ if $\mathrm{BMD}$ was low and $7.0 \%$ (Cl: 5.5-8.5) if BMD was normal.

\section{Conclusion}

In postmenopausal women, clinical fractures cluster in time. One in two women with a recent clinical fracture had a new clinical fracture within 5 years, regardless of BMD. The 5-year AR for a first clinical fracture was much lower and depended on BMD. 


\section{Introduction}

A ccording to the World Health Organisation (WHO), osteoporosis is the second leading health problem in the developed world in terms of numbers, ${ }^{1,2}$ owing to the ageing of the western female population. ${ }^{1-9}$ The incidence of fractures is related to the age of the population, and to skeletal and extra-skeletal factors. ${ }^{1-9}$ The worldwide lifetime risk of osteoporotic fractures in women is $40 \%$, and because of the ageing of the population, the overall prevalence of osteoporotic fractures is expected to rise considerably. ${ }^{10}$ The mortality rate for hip fractures varies between 15 and $30 \% .{ }^{10-12}$ In 1990 , there were 1.7 million hip fractures worldwide, and this could increase to 6.3 million by $2050 .^{10}$ The resulting hospital costs alone amount to over US $\$ 3976$ million in the European Union, US $\$ 500$ million in Australia, US $\$ 5700$ million in the USA, and US $\$ 9359$ million in Japan. ${ }^{10}$ In view of this high morbidity, mortality and economic burden, it is important to identify those groups of patients who are at high risk and for whom interventions to prevent osteoporotic fractures would be most effective. . $^{3,4-9}$

In 1992-94, a cross-sectional population-based study assessed BMD and other determinants that might influence osteoporosis among 4203 postmenopausal women aged 50 to $80 .^{7-9} \mathrm{~A}$ random sample of women from the above study was re-examined 5 to 6 years later, allowing us to study the prognostic value of relevant determinants of experiencing a fracture.

Several researchers have addressed the same subject, ${ }^{13-22}$ and the WHO is currently developing a fracture risk assessment tool with which family physicians can predict 5-year and 10-year fracture risk. ${ }^{23}$ However, data are scarce about the absolute risk (AR) of fractures and the timing of a previous clinical fracture. ${ }^{14-16}$ Available studies suggest that fracture risk is highest immediately after a fracture, with the risk of an osteoporotic fracture being $12.0 \%{ }^{14}$ and that of any fracture being $12.2 \%$ during the first 2 years. ${ }^{16}$ The risk of morphological vertebral fractures is $19.2 \%$ at 1 year after a previous morphological vertebral fracture. ${ }^{15}$ The goal of our study was to assess the 5year AR of incident clinical fractures among postmenopausal women. 


\section{Methods}

\section{Participants}

In total, 20 general practitioners (GPs) from 10 general practice centres participated. The participating general practices were invited based on their familiarity with the rules of 'good clinical practice' and based on their participation in earlier studies. The region can best be described as consisting of two cities surrounded by suburban villages. ${ }^{7}$

A random sample of 1686 postmenopausal women, aged between 50 and 80 years, was drawn from the above study population. ${ }^{7-9}$ Participating women signed an informed consent form.

\section{Measurements}

The assessments in 1992-94 started with weight (in kilograms), height (in centimetres), and BMD (measured by a computer-guided DXA instrument; Hologic QDR-1000, Hologic Europe, Brussels, Belgium). Four experienced and specially trained research nurses performed all the measurements. After the measurements, the participants completed a questionnaire, which concentrated on variables possibly related to osteoporosis or low BMD..$^{7-9}$ In addition, all women were questioned about their medical history (including fracture history), family history and diet. $^{7}$

In the 1998-2000 assessments, one specially trained research nurse, or the principal investigator, completed a questionnaire in the presence of the participant, which recorded the history of fractures. The research assistant confirmed all fractures reported by the patients by searching the medical files in the participating GP centres. In the Netherlands, clinical fractures are treated in hospital and then reported to the patient's GP, who always includes this information in the patient's medical file. In our study, every fracture reported by a patient could thus be confirmed by her medical file.

\section{Statistical analysis}

SPSS software (version 11.0; SPSS Inc., Chicago, IL, USA) was used for the statistical analysis. The dependent variable was the first fracture suffered by a woman after baseline, taking only the first fracture after menopause into account. A power calculation for our main variable (timing of a previous fracture) was performed. This calculation compared two proportions. ${ }^{24}$

The hazard of first fracture and the death hazard were used to compute the 5year probability of fractures. Univariate Cox regression analysis was used to 
analyse possible predictors of suffering a fracture. Before being entered into the regression analysis, the non-discrete variables were dichotomised at the mean. The cut-off points for coffee intake per day and alcohol intake per week were set at five or more consumptions. The variables 'smoking' and 'sports', both past and present, were dichotomised as yes/no. The resulting significant variables were entered into a multivariate Cox regression to calculate the 5-year probability of fracture.

Further analysis investigated the influence of timing of a previous clinical fracture. A discrete variable was used, categorised as participants with a recent previous fracture (in the past 5 years; $n=68$ ) and participants with an older previous fracture (longer than 5 years previously, but still after menopause; $n=$ 62). The 5-year cut-off point was the optimum compromise between finding a sufficient number of fractures to allow statistical evaluation and minimising the loss to recall. ${ }^{7}$ Thereafter, a multivariate subgroup analysis was performed, including the timing of previous fractures. These significant determinants were used to construct algorithms, which included relative risk (RR), AR and 95\% confidence intervals $(\mathrm{Cl})$.

At baseline (1992-94), BMD values for lumbar spine were divided into two categories: BMD T-score $\leq-1.0$ (including osteoporosis plus osteopenia) and Tscore $>-1.0$, according to WHO criteria. ${ }^{1}$

\section{Ethics}

The Ethics Review Committee of the Maastricht University and the Maastricht University Hospital approved the study (reference number MEC 94-196.1).

\section{Results}

Of the 1686 women, 1207 were traceable and alive, and 759 agreed to take part in the follow-up measurement. This corresponded to a response rate of $62.9 \%$ of the traceable and surviving women (Figure 1). Non-participating women were compared with participating women in terms of the baseline variables. Age was the only variable that differed between the responders and non-responders; non-participants were on average 3.5 years older than participants. 


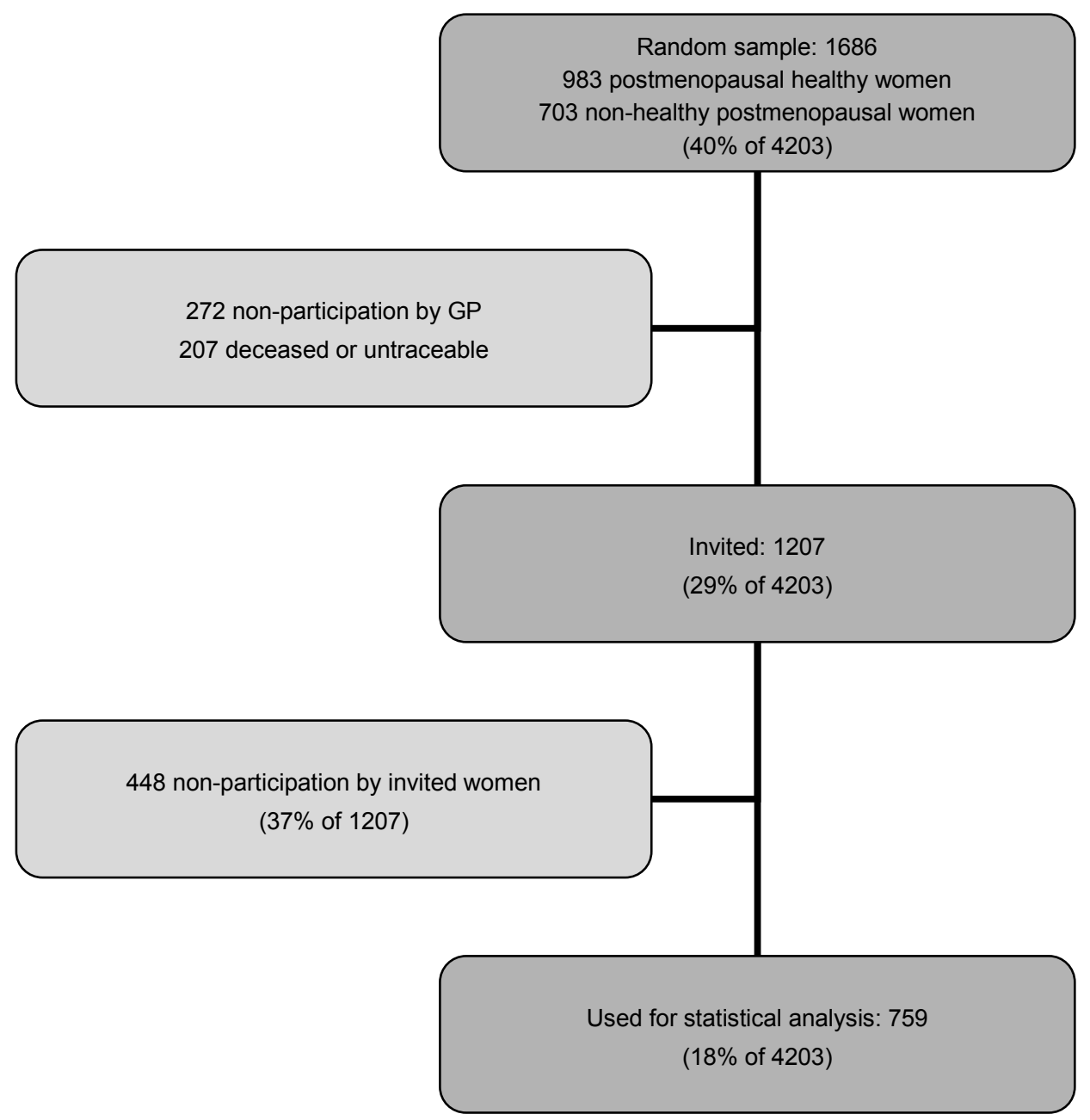

Figure 1 Flow-chart of patient inclusion.

The power calculation compares a recent previous fracture $(n=68)$ versus an older previous fracture $(n=62)$. The two proportions were $0.50(34 / 68)$ and 0.19 $(12 / 62)$, which resulted in a two-sided power of 0.95 . This result showed that the study was sufficiently powered.

The characteristics of the study population at baseline (1992-1994) are shown in Tables 1 (continuous variables) and 2 (discrete variables). In total, 95 women (12.5\%, Cl: 10.1-14.9) had a clinical fracture during the 5-year follow-up (Table 3). 
Table 1 Description of the study population at baseline (1992-94): continuous variables $(\mathrm{n}=759)$.

\begin{tabular}{lccc}
\hline Variable & Mean & SD & Range \\
\hline Bone mineral density (BMD, $\mathrm{g} / \mathrm{cm}^{2}$ ) & 0.94 & 0.17 & $0.46-1.59$ \\
Age (years) & 61.0 & 6.8 & $50.1-79.4$ \\
Weight $(\mathrm{kg})$ & 70.9 & 11.6 & $45.0-115$ \\
Height $(\mathrm{cm})$ & 162 & 6.2 & $142-183$ \\
Body mass index (BMI, $\mathrm{kg} / \mathrm{m}^{2}$ ) & 27.1 & 4.2 & $18.0-45.0$ \\
Fertility years ${ }^{\mathrm{b}}$ & 33.0 & 6.4 & $5.0-46.0$ \\
Pregnancies & 2.9 & 2.1 & $0.0-14.0$ \\
Coffee intake (cups per day) & 5.1 & 3.3 & $0.0-30.0$ \\
Alcohol intake (glasses per week) & 1.8 & 5.3 & $0.0-42.0$ \\
Cigarettes per day smoked in the past & 3.4 & 8.5 & $0.0-50.0$ \\
Years of smoking in the past & 4.8 & 11.3 & $0.0-54.0$ \\
Cigarettes per day smoked in the present & 3.9 & 7.7 & $0.0-50.0$ \\
Years of smoking in the present & 9.2 & 16.3 & $0.0-57.0$ \\
Calcium intake (mg per day) & 903 & 407 & $133-2812$ \\
\hline
\end{tabular}

a $\mathrm{SD}$ = standard deviation

b Fertility years = age at last menstruation - age at first menstruation

Table 2 Description of the study population at baseline (1992-94): discrete variables $(n=759)$.

\begin{tabular}{lcc}
\hline Variable & Risk factor present & Percentage \\
\hline Osteoporosis (T-score $\leq-2.5$ ) & 155 & 20.4 \\
Osteopenia (-2.5 - T-score $\leq-1.0)$ & 306 & 40.3 \\
Normal bone mineral density (BMD, T-score > -1.0) & 298 & 39.3 \\
Fracture history after menopause & 130 & 17.1 \\
Use of birth control pill > 5 years & 132 & 17.4 \\
Use of hormones $>$ 5 years & 48 & 6.3 \\
Ovariectomy & 116 & 15.3 \\
Hysterectomy & 287 & 37.8 \\
Menopause below the age of 45 years & 255 & 33.6 \\
Perimenopausal complaints & 226 & 29.8 \\
Family history of osteoporosis & 96 & 12.6 \\
Coffee intake $\geq 5$ per day & 379 & 49.9 \\
Alcohol intake $\geq 5$ per week & 109 & 14.4 \\
Cigarette smoking in the past & 157 & 20.7 \\
Cigarette smoking in the present & 200 & 26.4 \\
Sports at the present & 469 & 61.8 \\
Sports at the past & 455 & 59.9 \\
Occupational exercise in the past & & \\
$\quad$ Mild & 122 & 16.1 \\
$\quad$ Moderate & 610 & 80.4 \\
$\quad$ High & 24 & 3.2 \\
\hline
\end{tabular}


The univariate Cox regression showed that low BMD (T-score $\leq-1.0$ ), increasing age, a history of clinical fracture after menopause, and current or past smoking were significant predictors of a new clinical fracture (Table 4).

As shown in Table 1, there seemed to be some very low values for calcium intake. In an extended univariate Cox regression analysis to investigate the influence of this factor, the lowest quintile and quartile of calcium intake were excluded. This exclusion did not change the results (hazard ratio (HR): $1.4, \mathrm{Cl}$ : 0.9-2.2; and HR: 1.3, Cl: 0.8-2.0, respectively).

Table 3 Location and number of fractures during the 5-year follow-up period $(n=95)$.

\begin{tabular}{|c|c|c|}
\hline Location & Number & Percentage \\
\hline Vertebra & 7 & 7.4 \\
\hline Rib & 2 & 2.1 \\
\hline \multicolumn{3}{|l|}{ Upper extremities } \\
\hline Humerus & 14 & 14.7 \\
\hline Wrist & 30 & 31.6 \\
\hline Hand & 5 & 5.3 \\
\hline Other & 8 & 8.4 \\
\hline \multicolumn{3}{|l|}{ Upper extremities } \\
\hline Hip & 5 & 5.3 \\
\hline Femur & 6 & 6.3 \\
\hline Foot & 8 & 8.4 \\
\hline Other & 10 & 10.5 \\
\hline Total & 95 & 100 \\
\hline
\end{tabular}

These significant determinants were entered into a multivariate Cox regression. The results of this analysis showed that a previous fracture (HR: $5.0, \mathrm{Cl}: 3.4-$ 7.5) was a significant risk factor, and an interaction was found between a previous fracture and BMD. Low BMD contributed significantly only in the presence of interaction, and was therefore an effect modifier. Low BMD was not a significant predictor for patients with a previous fracture $(n=130 ; \mathrm{HR}: 1.5, \mathrm{Cl}$ : $0.8-2.8)$, but was for those without $(n=629 ; \mathrm{HR}: 2.9, \mathrm{Cl}: 1.5-5.8)$.

Table 3 shows the details of 31 hand, foot and other fractures. Of these 31 fractures, 12 were caused by a traumatic accident (for example, fall from stairs or bicycle, or fractures incurred during sports). We therefore excluded these 12 fractures from an extended analysis. Multivariate Cox regression again showed that a previous fracture (HR: $5.0, \mathrm{Cl}: 3.2-7.8)$ was the most significant risk factor. Furthermore, low BMD contributed significantly only in the presence of an interaction, and was a significant predictor only for those without a previous fracture ( $\mathrm{n}=629$; HR: $2.5, \mathrm{Cl}: 1.2-5.0)$. Thus, we found that excluding the 
fractures caused by a trauma did not change the results and they were therefore not excluded from further analysis.

Table 4 Univariate Cox regression, hazard ratio and 95\% confidence interval $(\mathrm{Cl})(\mathrm{n}=759)$.

\begin{tabular}{|c|c|c|}
\hline Variable & Hazard ratio & $\mathrm{Cl}$ \\
\hline Bone mineral density (BMD, T-score $\leq 0.95$ ) & 1.8 & $1.2-2.8$ \\
\hline Osteoporosis (T-score $\leq-2.5$ ) & 1.5 & $0.9-2.3$ \\
\hline Osteopenia $(-2.5<$ T-score $\leq-1.0)$ & 1.3 & $0.9-2.0$ \\
\hline Low BMD (T-score $\leq-1.0)$ & 1.9 & $1.2-3.1$ \\
\hline Age $>60$ years & 1.7 & $1.1-2.6$ \\
\hline Weight $\leq 70 \mathrm{~kg}$ & 1.2 & $0.8-1.8$ \\
\hline Height $>160 \mathrm{~cm}$ & 1.0 & $0.6-1.5$ \\
\hline Body mass index $(\mathrm{BMI}) \leq 27 \mathrm{~kg} / \mathrm{m} 2$ & 1.1 & $0.8-1.7$ \\
\hline Fertility years ( $\leq 35$ years) & 1.0 & $0.7-1.6$ \\
\hline Pregnancies $>3$ & 1.4 & $0.9-2.1$ \\
\hline Calcium intake $\leq 900 \mathrm{mg}$ & 1.3 & $0.9-2.0$ \\
\hline Positive fracture history after menopause & 5.2 & $3.4-7.7$ \\
\hline Use of birth control pill > 5 years & 1.2 & $0.7-1.9$ \\
\hline Use of hormones $>5$ years & 3.3 & $0.8-13.6$ \\
\hline Ovariectomy & 1.1 & $0.7-1.9$ \\
\hline Hysterectomy & 1.1 & $0.7-1.7$ \\
\hline Menopause below the age of 45 years & 1.2 & $0.8-1.8$ \\
\hline Perimenopausal complaints & 1.4 & $0.9-2.3$ \\
\hline Family history of osteoporosis & 1.2 & $0.7-2.1$ \\
\hline Coffee intake $\geq 5$ per day & 1.3 & $0.9-1.9$ \\
\hline Alcohol intake $\geq 5$ per week & 1.0 & $0.6-1.8$ \\
\hline Cigarette smoking in the past & 1.6 & $1.0-2.4$ \\
\hline Cigarette smoking in the present & 1.7 & $1.0-2.8$ \\
\hline Sports at the past & 1.0 & $0.6-1.4$ \\
\hline Sports at the present & 1.0 & $0.6-1.5$ \\
\hline \multicolumn{3}{|l|}{ Occupational exercise in the past } \\
\hline Mild & 1.2 & $0.7-2.0$ \\
\hline Moderate / High & Reference & Reference \\
\hline
\end{tabular}


The multivariate subgroup analysis, including the timing of a previous fracture, showed that a recent previous fracture contributed significantly more to the risk of a new clinical fracture than did an older previous fracture (HR: 3.2, $\mathrm{Cl}$ : 1.76.3). Thus, whether a previous fracture was recent was an important risk factor for suffering a new clinical fracture. This result is illustrated in the cumulative survival plot of the postmenopausal women with a previous fracture (Figure 2), and shows clearly that a recent previous fracture previous fracture was a much more important risk factor than an older previous fracture $\left(R^{2}=0.98\right.$ for an exponential trend line and 0.76 for a linear trend line).

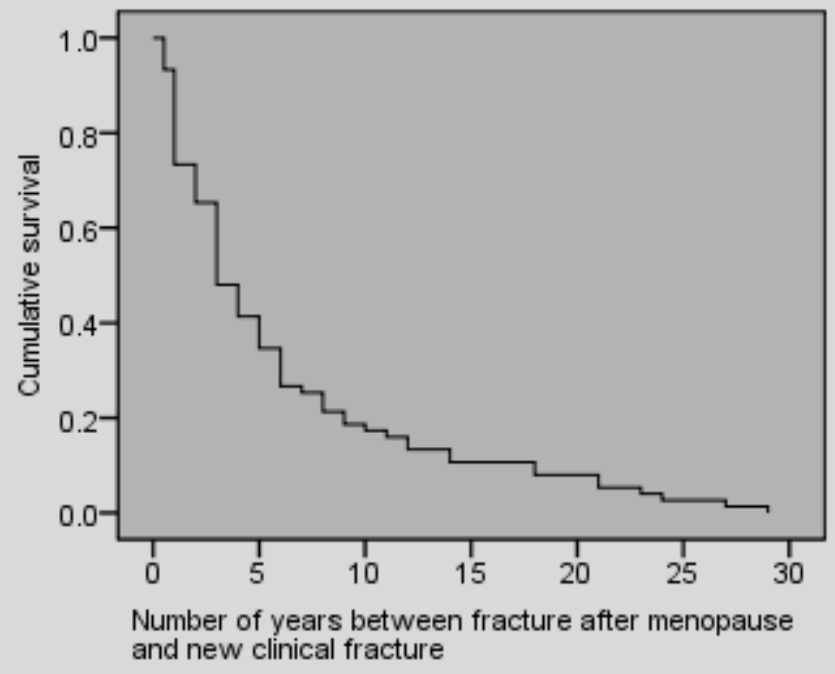

Figure 2 Cumulative survival plot for postmenopausal women with a previous fracture $(n=130)$.

The AR for incident clinical fracture was $50.1 \%(\mathrm{Cl}: 42.0-58.1)$ in women with a recent previous fracture, and $21.2 \%(\mathrm{Cl}: 20.7-21.6)$ in women with an older previous fracture (Table 5). In women without a fracture history after menopause, BMD was a significant predictor. The participants without a fracture history and with normal BMD ( $\mathrm{T}>-1.0)$ had an AR of $7.0 \%(\mathrm{Cl}: 5.5-8.5)$. This risk was $44.0 \%$ lower than that in the total study population $(12.5 \%)$, and this subgroup represented $35.0 \%$ of the total study population. Women without a previous fracture and with low BMD had an AR of $13.8 \%(\mathrm{Cl}: 10.9-16.6)$, which was $10.4 \%$ higher than that of the total study population (Table 5 ). 
Table 5 Algorithm of risk factors for a new clinical fracture: Absolute risks (ARs) plus (95\% confidence intervals), and relative risks (RRs) for the subgroup with $(\mathrm{n}=130)$ and without $(n=629)$ a fracture history (total $n=759)$.

\begin{tabular}{|c|c|c|c|c|c|}
\hline \multirow{2}{*}{$\begin{array}{l}\text { A. } \\
\text { Recent fracture } \\
\text { (past 5-years) } \\
\text { yes / no }\end{array}$} & \multicolumn{5}{|c|}{ Previous fracture $(n=130)$} \\
\hline & $\begin{array}{l}\text { Number of } \\
\text { participants }\end{array}$ & $\begin{array}{l}\text { Fractures / } \\
\text { person-years }\end{array}$ & $\begin{array}{c}\text { Percentage of } \\
\text { the total } \\
\text { population }\end{array}$ & $\begin{array}{c}\text { AR for } \\
\text { fractures }(\mathrm{Cl})\end{array}$ & $\begin{array}{l}\text { RR for } \\
\text { fractures }\end{array}$ \\
\hline \multirow[t]{2}{*}{ yes } & 68 & $34 / 236$ & 9.0 & 50.1 & 6.4 \\
\hline & & & & $(42.0-58.1)$ & \\
\hline \multirow[t]{2}{*}{ no } & 62 & $12 / 283$ & 8.2 & 21.2 & 2.7 \\
\hline & & & & $(20.7-21.6)$ & \\
\hline A. & \multicolumn{5}{|c|}{ No previous fracture $(n=629)$} \\
\hline $\begin{array}{c}\text { Low BMD } \\
\text { (T-score } \leq-1.0) \\
\text { yes / no } \\
\end{array}$ & $\begin{array}{l}\text { Number of } \\
\text { participants }\end{array}$ & $\begin{array}{c}\text { Fractures / } \\
\text { person-years }\end{array}$ & $\begin{array}{c}\text { Percentage of } \\
\text { the total } \\
\text { population }\end{array}$ & $\begin{array}{c}\text { AR for } \\
\text { fractures }(\mathrm{Cl})\end{array}$ & $\begin{array}{l}\text { RR for } \\
\text { fractures }\end{array}$ \\
\hline yes & 363 & $39 / 1724$ & 47.8 & $\begin{array}{c}13.8 \\
(10.9-16.6)\end{array}$ & 2.0 \\
\hline no & 266 & $10 / 1299$ & 35.0 & $\begin{array}{c}7.0 \\
(5.5-8.5)\end{array}$ & $1.0^{b}$ \\
\hline
\end{tabular}

a Significant risk factors for a new clinical fracture based on multivariate Cox survival analysis; $\mathrm{BMD}=$ bone mineral density

b Reference

\section{Discussion}

The results show that clinical fractures in postmenopausal women cluster in time. One in two women with a recent previous clinical fracture had a new clinical fracture within 5 years, regardless of BMD. The 5-year AR for a first clinical fracture was much lower and depended on BMD.

The HR of a previous fracture (5.0) is higher than the 2.0 reported in a large meta-analysis; ${ }^{5}$ however, our analysis showed that having an older previous fracture $(n=62)$ led to an HR of 2.5, which is closer to the reported AR. The results show that a recent previous fracture is a more important predictor of a new clinical fracture than is an older previous fracture. Owing to effect modification, the algorithm differs between the subgroups with and without a previous fracture, leading to a stronger prediction model per subgroup. This allowed a low-risk group (35.0\%) to be identified, consisting of women who can be spared a great deal of unnecessary worry. Nevertheless, $17.1 \%$ of the population were at very high risk. 
The incidence of vertebral fractures may have been underestimated in our study because only clinical fractures were used. Morphometric fractures that do not come to clinical attention have significance and are not without symptoms. ${ }^{25,26}$ Kanis et al. ${ }^{27}$ showed that the 10 -year vertebral probability of morphometric fractures was higher than for clinical fractures alone. Furthermore, morphometric fractures increase the risk of a new clinical fracture significantly and are, therefore, of prognostic significance. ${ }^{15}$ BMD, especially measured at the spine, is a strong predictor of a first vertebral fracture. ${ }^{28}$ All women in our study with a clinical vertebral fracture $(n=7)$ had a low BMD. Thus, our AR is generally an underestimate compared with the AR of fractures found when all morphometric fractures were taken into account.

The factors that were independent and significant predictors of fracture risk in our study have been investigated previously, leading to partly comparable results. However, limited data are available about absolute fracture risk and the timing of a previous clinical fracture ${ }^{14-16}$ when controlling for most other risk factors. Our study differs from previous studies in some methodological aspects. Firstly, some studies used prospective data, but presented a risk prediction tool for 1 year, ${ }^{14-16,22,29}$ which could be too short a time span. Secondly, many studies developed a prediction model specially for hip or vertebral fractures, ${ }^{13,15,17-20}$ while we included all fractures. Finally, previous results may have differed from ours in terms of geographical factors. For example, the participants of the Dubbo Osteoporosis Study ${ }^{20}$ lived in a region with considerably more sunshine than in northern Europe, which might result in different vitamin D levels. ${ }^{30,31}$

Age has been documented as a risk factor for fractures in several studies. In our study, age was a significant risk factor for a new clinical fracture only in the univariate analysis. One reason could be that we studied a relatively young population compared with other prospective studies, and the timing of a previous fracture is the main risk for new fractures for this population. All women were aged $50-80$ years, with only $12.0 \%$ of the population aged 70 years and over, whereas women included in other studies were aged 65 years and over. ${ }^{19-21}$ It is possible that our ARs are an underestimate, due to the 3.5year age difference between the responders and non-responders. However, our results hardly differ from other studies, such as that of Johnell et al. ${ }^{32}$ Based on person-years, our absolute fracture risk was $2.7 \%$ (95/3542), which is close to the AR reported by Johnell et al (AR: $2.2 \%$; 3694/168366). ${ }^{32}$

Our study was subject to some limitations. BMD measurement was performed on the lumbar spine, a measurement that can be influenced by osteoarthritis among the elderly. Measurements at the hip could have given additional 
information, but this had not been performed at baseline (1992-94). Furthermore, 45 participants $(5.9 \%)$ received advice about calcium intake and exercise after baseline measurements. Some participants may have heeded this advice, and may therefore have improved their lifestyle. However, the advice differed little from the recommendations regularly made to the general public, on which women may also act. One other factor that may have affected the results is the previous use of medication. However, only the 45 women mentioned above were being treated for osteoporosis (including treatment with a placebo), and excluding these participants from the analysis did not change the results. Finally, our sample size was relatively small in comparison with that in other studies. Johnell et al. ${ }^{32}$ studied 38973 men and women ( $75 \%$ women) from 12 prospective cohorts. The total number of osteoporotic and nonosteoporotic fractures in these cohorts was $3694(\mathrm{AR}=9.5 \%)$. $^{32}$ This indicates that even though our sample was relatively small, our absolute fracture risk was still higher than the AR of Johnell's 12 prospective cohorts. ${ }^{32}$ Based on personyears instead of numbers of participants, as mentioned previously, our absolute fracture risk was $2.7 \%(95 / 3542)$, which is close to the AR reported by Johnell et al. $(A R=2.2 \% ; 3694 / 168366){ }^{32}$

\section{Conclusion}

The main conclusion of our study is that a recent previous fracture is a relevant factor in detecting postmenopausal women at high risk. One in two women with a recent previous fracture had a new clinical fracture within 5 years, regardless of BMD. This might be interesting information for a variety of professionals: GPs and hospital specialists can use it to quickly and accurately assess which postmenopausal women are at high or low risk, and thus, for which women fracture prevention should be initiated immediately. Future research should try to verify our results using a longer follow-up period. 


\section{References}

1. Anonymous. Assessment of fracture risk and its application to screening for postmenopausal osteoporosis. Report of a WHO Study Group. World Health Organization technical report series 1994; 843: 1-129.

2. Hamblen D. Who cares for the patient with a fragility fracture? Orthop Today Internat $2004 ; 7$.

3. Boereboom FTJ, Groot de RRM, Raymakers JA, et al. The incidence of hip fractures in The Netherlands. Neth J Med. 1991; 38: 51-8.

4. CBO. Osteoporose Tweede Herziene Richtlijn. 2002, Alphen aan de Rijn: Van Zuiden Communications B.V.

5. Klotzbuecher CM, Ross PD, Landsman PB, et al. Patients with prior fractures have an increased risk of future fractures: a summary of the literature and statistical synthesis. J Bone Miner Res 2000; 15(4): 721-7.

6. Riggs BL, Melton III LJ. The worldwide problem of osteoporosis: insights afforded by epidemiology. Bone 1995; 17(5): 505-11S.

7. Voort van der DJM, Dinant GJ, Rinkens PELM, et al. Construction of an algorithm for quick detection of patients with low bone mineral density and its applicability in daily general practice. J Clin Epidemiol 2000; 53: 1095-103.

8. Voort van der DJM, Geusens PP, Dinant GJ. Risk factors for osteoporosis related to their outcome: fractures. Osteoporos Int 2001; 12: 630-8.

9. Voort van der DJM, Weijer van der PHM,Barentsen R. Early menopause: Increased fracture risk at older age. Osteoporos Int 2003; 14: 525-30.

10. Delmas PD, Fraser M. Strong bones in later life: luxury or necessity? Bull World Health Organ 1999; 77(5): 416-22.

11. Browner WS, Pressman AR, Nevitt MC, et al. Mortality following fractures in older women. The study of osteoporotic fractures. Arch Intern Med 1996; 156(14): 1521-5.

12. Keene GS, Parker MJ,Pryor GA. Mortality and morbidity after hip fractures. BMJ 1993; 307(6914): 1248-50.

13. Burger $\mathrm{H}$, De Laet $\mathrm{CE}$, Weel AEAM, et al. Added value of bone mineral density in hip fracture risk scores. Bone 1999; 25(3): 369-74.

14. Johnell $\mathrm{O}$, Kanis JA, Oden A, et al. Fracture risk following an osteoporotic fracture. Osteoporos Int 2004; 15(3): 175-9.

15. Lindsay RL, Silverman SL, Cooper C, et al. Risk of new vertebral fracture in the year following a fracture. JAMA 2001; 285(3): 320-3.

16. Helden van $\mathrm{S}$, Cals J, Kessels $\mathrm{F}$, et al. Risk of new clinical fractures within 2 years following a fracture. Osteoporos Int 2006; 17(3): 348-54.

17. Cummings SR, Nevitt MC, Browner WS, et al. Risk factors for hip fracture in white women. $\mathrm{N}$ Engl J Med 1995; 332(12): 767-73.

18. Klift van der M, Laet de CEDH, McCloskey EV, et al. Risk factors for incident vertebral fractures in men and women: the Rotterdam Study. J Bone Miner Res 2004; 19(7): 1172-80.

19. McGrother CW, Donaldson MM, Clayton D, et al. Evaluation of a hip fracture risk score for assessing elderly women: the Melton Osteoporotic Fracture (MOF) study. Osteoporos Int 2002; 13(1): 89-96.

20. Nguyen ND, Pongchaiyakul C, Center JR, et al. Identification of high-risk individuals for hip fracture: a 14-year prospective study. J Bone Mineral Res 2005; 20(11): 1921-8.

21. Black DM, Steinbuch $M$, Palermo $L$, et al. An assessment tool for predicting fracture risk in postmenopausal women. Osteoporos Int 2001; 12(7): 519-28. 
22. Siris ES, Miller PD, Barrett-Connor E, et al. Identification and fracture outcomes of undiagnosed low bone mineral density in postmenopausal women: results from the National Osteoporosis Risk Assessment. JAMA 2001; 286(22): 2815-22.

23. International Osteoporosis Foundation. WHO Working Group on Fracture Risk Assessment. 2005; Available from: http://www.osteofound.org/activities/world_health_organization.html.

24. Lenth R. Java Applets for Power and Sample Size (computer software). 2006; Available from: http://www.stat.uiowa.edu/ rlenth/Power.

25. Nevitt MC, Ettinger B, Black DM, et al. The association of radiographically detected vertebral fractures with back pain and function: a prospective study. Ann Intern Med 1998; 128(10): 793800.

26. Nevitt MC, Thompson DE, Black DM, et al. Effect of alendronate on limited-activity days and bed-disability days caused by back pain in postmenopausal women with existing vertebral fractures. Fracture Intervention Trial Research Group. Arch Intern Med 2000; 160(1): 77-85.

27. Kanis JA, Johnell $O$, Oden A, et al. The risk and burden of vertebral fractures in Sweden. Osteoporos Int 2004; 15(1): 20-6.

28. Nevitt MC, Cummings SR, Stone $\mathrm{KL}$, et al. Risk factors for a first-incident radiographic vertebral fracture in women $>$ or $=65$ years of age: the study of osteoporotic fractures. $\mathrm{J}$ Bone Miner Res 2005; 20(1): 131-40.

29. Miller PD, Barlas S, Brenneman SK, et al. An approach to identifying osteopenic women at increased short-term risk of fracture. Arch Intern Med 2004; 164(10): 1113-20.

30. Climate Information Service NCC, Bureau of Meteorology. Mean hours of bright sunshine. 2004, Melbourne.

31. KNMI. Aantal uren zonneschijn. 2004, De Bilt.

32. Johnell $\mathrm{O}$, Kanis JA, Oden $\mathrm{A}$, et al. Predictive value of BMD for hip and other fractures. J Bone Mineral Res 2005; 20(7): 1185-94. 


\section{Chapter 3}

\section{Risk factors for clinical fractures among postmenopausal women: a 10-year prospective study}

Tineke van Geel, Piet Geusens, Ivo Nagtzaam, Danny van der Voort, Cyril Schreurs, Paula Rinkens and Geert-Jan Dinant

Menopause Int 2007; 13: 110-115 


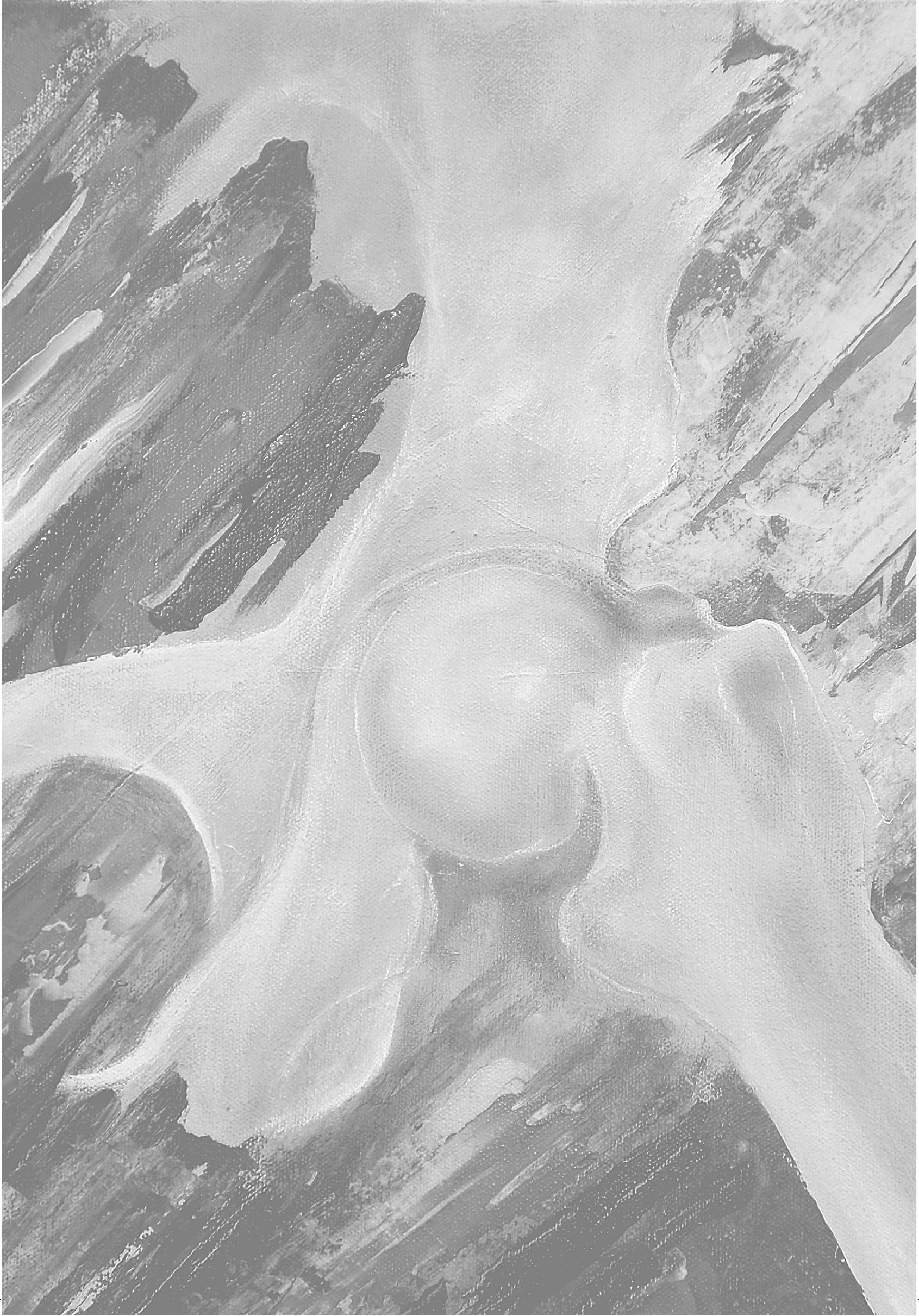




\section{Abstract}

\section{Introduction}

Only scarce data are available on the long-term absolute risk (AR) of all clinical fractures, taking into account the time when they occurred. Therefore, we assessed during a 10-year follow-up the risk factors associated with the occurrence of any first or second clinical fracture.

\section{Methods}

This was a population-based study in 10 general practice centres. The sample comprised 2372 postmenopausal women, aged between 50 and 80 years at baseline, who completed a questionnaire about the incidence of radiographically confirmed fractures and fracture risks, analysed by multivariate Cox regression. The ARs for any clinical fracture were calculated.

\section{Results}

During the 10-year follow-up, 380 women (16\%) had a fracture. A first fracture occurred in 267 women (11\%). Osteoporosis at the lumbar spine (T-score $\leq$ - 2.5; hazard ratio (HR): 1.8, 95\% confidence interval (Cl): 1.4-2.3) and age over 60 years (HR: $1.4, \mathrm{Cl}: 1.1-1.8)$ were the only risk factors retained in the Cox analysis. The AR in the lowest-risk group was $10 \%$, and it was $23 \%$ in the highest-risk group. A second fracture occurred in 113 women during follow-up $(5 \%)$. The time when a fracture occurred was the only risk factor retained in the Cox analysis. The AR for a second fracture was $41 \%$ in the five years after any first fracture before baseline and $25 \%$ if the first fracture had occurred earlier (HR: 1.8, Cl: 1.3-2.7).

\section{Conclusion}

In postmenopausal women, over a 10-year follow-up, the AR of a second clinical fracture is highest in the five years after any first clinical fracture. The AR for a first clinical fracture is lower and depends on osteoporosis and age. 


\section{Introduction}

The incidence of fractures is rising because of the ageing population. ${ }^{1-3}$ In at 3.79 million, 0.89 million of which were hip fractures. The direct costs were estimated at $€ 31.7$ billion, and in 2050 the costs are expected to increase to $€ 76.7$ billion, based on the expected demographic changes in Europe. ${ }^{4}$ Therefore, guidelines on osteoporosis all advocate clinical case finding to identify those groups of patients at high risk in whom interventions to prevent fractures are most effective, in view of the high morbidity, mortality and economic burden. ${ }^{4,5}$

Although prospective population-based studies ${ }^{6-12}$ show the incidence of fractures over a certain follow-up period, only some studies have taken into account the exact timing of the incidence of fractures. This is especially true for morphometric vertebral fractures, which are not accompanied by the clinical signs and symptoms of an acute fracture ${ }^{13}$ and the incidence of which is thus detectable only when radiography is performed at short intervals, such as annually. There are only a few reports available about the time course of clinical fractures. ${ }^{13-17}$ Several studies suggest that fracture incidence varies over time and that a further fracture is more likely immediately after a fracture than after a longer interval. ${ }^{13-17}$ Most of the studies discussed here, though, were short-term investigations; ${ }^{13,14,16,17}$ only one study reported a long-term prospective followup investigation, ${ }^{15}$ but no algorithm was constructed. Up to now, there have been no clinical algorithms available which can be used by the clinician to predict the 10-year absolute fracture risk, from one consultation, taking into account the time course of clinical fractures.

Therefore, the goal of our study was to assess the 10-year absolute risk of incident clinical fractures, taking into account the time when fractures occurred during the follow-up.

\section{Methods}

\section{Participants}

In 1992-94, a cross-sectional population-based study assessed 4203 postmenopausal women aged 50 to 80 years (at baseline). ${ }^{18,19}$ The study region can best be described as consisting of two cities in the southern part of the Netherlands, surrounded by suburban villages. ${ }^{18}$ 
By 2002, the study population had been reduced to 3633 (4203-570) postmenopausal women, as two general practices no longer participated.

\section{Measurements}

The assessments in 1992-94 included weight (in $\mathrm{kg}$ ), height (in $\mathrm{cm}$ ) and bone mineral density (BMD), measured using a computer-guided dual-energy X-ray absorptiometry (DXA) instrument. The measurements were done by four experienced and specially trained research nurses. The participants then completed a questionnaire, which concentrated on variables possibly related to osteoporosis or low BMD. ${ }^{18,19}$ All women were questioned about their medical history (including fracture history), family history and diet. ${ }^{18}$

Between 2003 and 2004, all women in the population received a letter informing them about the present follow-up study, as well as a questionnaire and a return envelope. The questionnaire enquired after their history of fractures in the 10 years since baseline measurements.

The risk of recall bias was kept to a minimum by asking a small number of uncomplicated questions. Since self-reports are more likely to result in overreporting, ${ }^{20}$ the research assistants checked all fractures reported by the patients in the medical files kept at the participating general practitioner (GP) centres. In the Netherlands, clinical fractures are treated at a hospital and then reported to the patient's GP, who always includes this information in the patient's medical file. In our study, every fracture reported by a patient could be confirmed in her medical file. It was assumed that all women remembered the fractures they had sustained.

\section{Statistical analysis}

SPSS software (version 12.0; SPSS Inc. Chicago, IL, USA) was used for the analysis. The dependent variable was the first fracture after menopause suffered by a person after the baseline measurement. The hazard of the first fracture was used to compute the 10-year probability of fractures. Univariate Cox regression was used to analyse possible determinants of a fracture. These analyses revealed significant determinants for a new clinical fracture over a 10year period. The data of the women who did not sustain a fracture after baseline were censored, meaning that the follow-up time was calculated from baseline measurement to the end of the study. Before being entered into the regression, all continuous variables were dichotomised at the mean. The 10-year probability of fractures was calculated, controlling for interactions, by entering these significant determinants into a multivariate Cox regression. The statistically 
significant determinants were used to construct an algorithm that included the relative risk $(R R)$ and absolute risk $(A R)$ of a new incident clinical fracture, as well as the $95 \%$ confidence intervals (Cls).

Previous studies revealed that a recent fracture is more important than an older one. $^{13-17}$ Therefore, subgroup analyses, univariate and multivariate Cox regressions, were performed in case significant interaction was found with the determinant 'previous fracture'. The subgroup analyses were used to investigate both risk factors for a first fracture, and the influence of the time that had elapsed between a first and second fracture. For that purpose, women with a fracture history were divided into two subgroups: women with a recent fracture history (past five years before baseline) and women with an earlier fracture history (longer than five years previously, but still after menopause). The fiveyear cut-off point to analyse the time that had elapsed between a previous fracture and a fracture after baseline was the optimum compromise between finding a sufficient number of fractures to allow statistical evaluation and minimising the loss to recall. ${ }^{18}$

As a cut-off point for the T-score, we used -2.5 (osteoporosis) for the baseline lumbar spine BMD, as it is a threshold for therapy in many guidelines on osteoporosis. ${ }^{21}$ This corresponded to 2.5 standard deviations (SD) below the mean L2-L4 BMD measured in a healthy female population aged 30 years. $^{18}$

\section{Ethics}

The Ethical Review Committee of Maastricht University and the Maastricht University Hospital approved the study (reference number MEC 94-196.1).

\section{Results}

Of the 3633 women, 2847 were traceable and alive, and 2372 of them agreed to participate. The response rate was thus $83.3 \%$ (Figure 1) of the traceable and surviving women. A comparison between non-responders and responders found significant differences for the following variables: age, mean (SD) 64.3 (7.7) versus $61.6(6.8)$ years $(p<0.01)$; height, mean (SD) 160.8 (6.4) versus $161.6(6.1) \mathrm{cm}(p<0.01)$; and BMD of the lumbar spine, mean (SD) $0.92(0.2)$ versus $0.93(0.2) \mathrm{g} / \mathrm{cm}^{2}(p=0.01)$. 


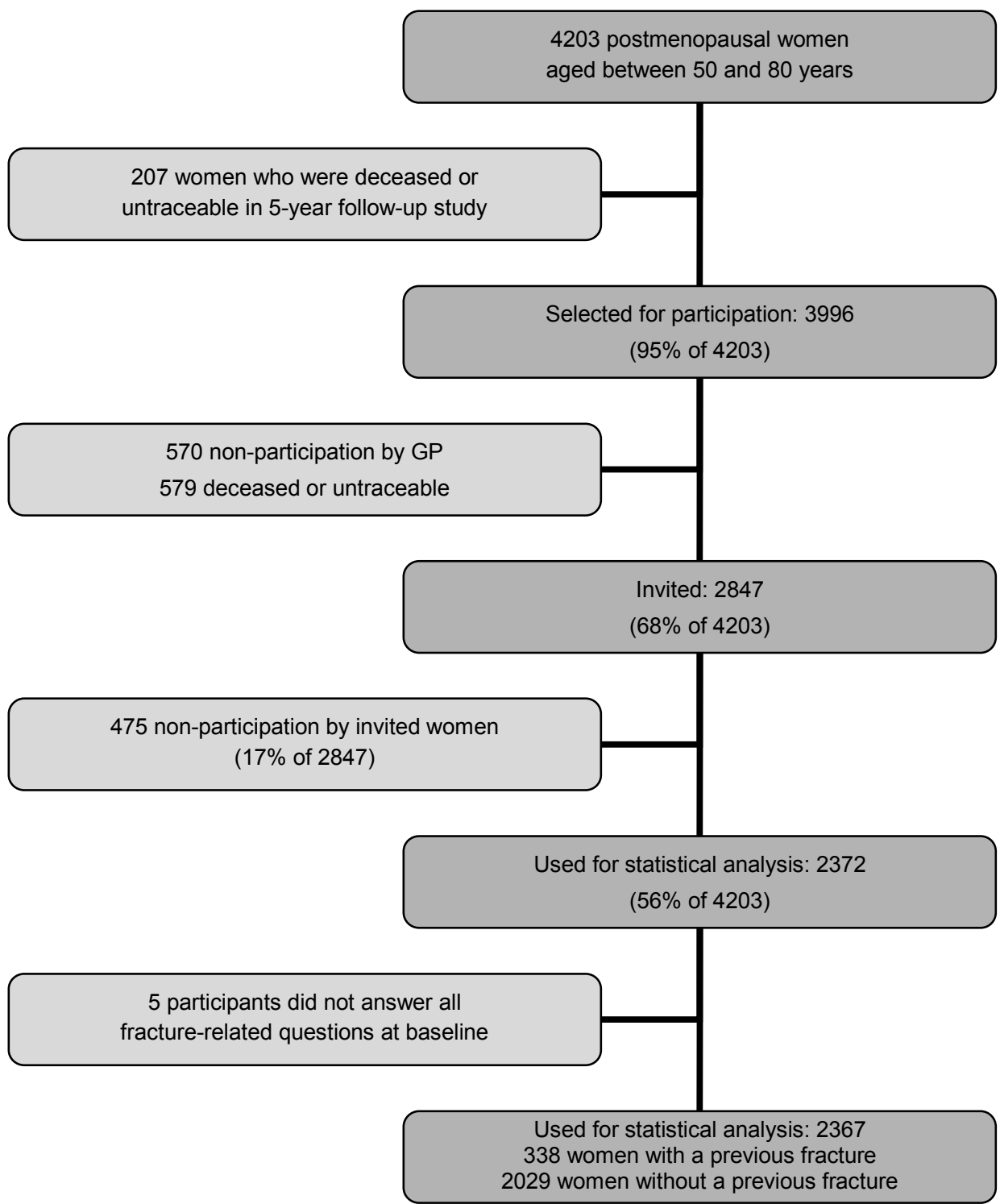

Figure 1 Flow-chart of patient inclusion.

The characteristics of the study population at baseline (1992-94) are shown in Table 1 (continuous variables) and Table 2 (discrete variables). During the 10year follow-up period, $380(16.0 \%)$ women had an incident clinical fracture (Table 3), $86.1 \%$ (327/380) of which were due to a fall from standing height or less. Five women did not answer the question about their fracture history and 
were therefore not included in further analyses. After baseline, 267 women $(11.3 \%$ of the total) without a fracture history $(n=2029)$ had a first fracture $(13.2 \%)$ and 113 women $(4.8 \%$ of the total) with a fracture history $(n=338)$ had a second fracture $(33.4 \%)$.

Table 1 Description of the study population at baseline (1992-94): continuous variables $(n=2372)$.

\begin{tabular}{lccc}
\hline Variable & Mean & $\mathrm{SD}^{\mathrm{a}}$ & Range \\
\hline Bone mineral density (BMD, $\mathrm{g} / \mathrm{cm}^{2}$ ) & 0.93 & 0.16 & $0.48-2.1$ \\
Age (years) & 61.6 & 6.8 & $50.0-80.0$ \\
Weight $(\mathrm{kg})$ & 71.3 & 11.7 & $40.0-140$ \\
Height $(\mathrm{cm})$ & 162 & 6.1 & $141-183$ \\
Body mass index (BMI, $\mathrm{kg} / \mathrm{m}^{2}$ ) & 27.3 & 4.4 & $15.0-53.0$ \\
Coffee intake (cups per day) & 5.0 & 3.3 & $0.0-35.0$ \\
Alcohol intake (glasses per week) & 1.9 & 5.1 & $0.0-42.0$ \\
Calcium intake (mg per day) & 877 & 399 & $85-2837$ \\
\hline
\end{tabular}

a $\mathrm{SD}=$ standard deviation

Table 2 Description of the study population at baseline (1992-94): discrete variables $(n=2372)$.

\begin{tabular}{|c|c|c|}
\hline Variable & Risk factor present & Percentage \\
\hline Osteoporosis (T-score $\leq-2.5$ ) & 503 & 21.2 \\
\hline Fracture history after menopause & 338 & 14.2 \\
\hline Use of systemic corticosteroids & 8 & 0.3 \\
\hline Family history of osteoporosis & 239 & 10.1 \\
\hline Rheumatoid arthritis & 46 & 1.9 \\
\hline Cigarette smoking in the present & 589 & 24.8 \\
\hline Sports at the present ${ }^{a}$ & 911 & 38.4 \\
\hline \multicolumn{3}{|l|}{ Occupational exercise in the past ${ }^{b}$} \\
\hline Mild & 332 & 14.0 \\
\hline Moderate & 1930 & 81.4 \\
\hline High & 95 & 4.0 \\
\hline
\end{tabular}

a Sports at the present: all sport-related physical activities (cycling, walking, playing tennis etc.), with no distinction between duration, level of activity and frequency

b Participants' assessment of physical nature of employment

The results of the univariate Cox regression are shown in Table 4. Some variables, for example calcium intake and body mass index (BMI), have various accepted cut-off points. The univariate Cox regression analyses were therefore extended and used alternative cut-off points for these, for example $1100 \mathrm{mg} / \mathrm{day}$ for women aged 50 to 70 years and $1200 \mathrm{mg} /$ day for women aged over 70 years for calcium intake ${ }^{22}$ and underweight, normal, overweight and obese for BMI. However, these variables still failed to be significant predictors of clinical fractures, independent of the chosen cut-off points (data not shown). 
Table 3 Location and number of fractures during the 10-year follow-up period $(n=380)$.

\begin{tabular}{lccc}
\hline Location & Number & Percentage \\
\hline Vertebra & 20 & 5.3 \\
Rib & 10 & 2.6 \\
Upper extremities & & \\
$\quad$ Humerus & 27 & 7.1 \\
$\quad$ Wrist & 132 & 34.7 \\
$\quad$ Other & 44 & 11.6 \\
$\quad$ Upper extremities & & \\
$\quad$ Hip & 47 & 12.4 \\
$\quad$ Femur & 9 & 2.4 \\
& Other & 91 & 23.9 \\
Total $\quad 380$ & 100 \\
\hline
\end{tabular}

Table 4 Univariate Cox regression, hazard ratio and 95\% confidence interval $(\mathrm{Cl})(\mathrm{n}=2367)$.

\begin{tabular}{lcc}
\hline Variable & Hazard ratio & $\mathrm{Cl}$ \\
\hline Osteoporosis (T-score $\leq-2.5)$ & 1.7 & $1.3-2.1$ \\
Age $>60$ years & 1.5 & $1.2-1.9$ \\
Weight $\leq 70 \mathrm{~kg}$ & 1.0 & $0.9-1.3$ \\
Height $>160 \mathrm{~cm}$ & 1.2 & $1.0-1.4$ \\
Body mass index (BMI) $\leq 27 \mathrm{~kg} / \mathrm{m}^{2}$ & 1.0 & $0.8-1.3$ \\
Coffee intake $>5$ per day & 1.0 & $0.8-1.3$ \\
Alcohol intake $>5$ per week & 1.3 & $1.0-1.7$ \\
Calcium intake $\leq 900$ mg & 1.0 & $0.8-1.2$ \\
Positive fracture history after menopause & 2.9 & $2.3-3.6$ \\
Use of systemic corticosteroids & 2.4 & $0.8-7.3$ \\
Family history of osteoporosis & 1.3 & $0.9-2.0$ \\
Rheumatoid arthritis & 1.2 & $0.6-2.4$ \\
Cigarette smoking in the present & 1.3 & $1.0-1.6$ \\
Sports at the present & 1.0 & $0.8-1.3$ \\
Occupational exercise in the past & & \\
$\quad$ Mild & 1.6 & $0.8-3.0$ \\
$\quad$ Moderate & 1.4 & $0.8-2.6$ \\
$\quad$ High & Reference & Reference \\
\hline Sports at the present: all sport-related physical activities (cycling, walking, playing tennis etc.), \\
with no distinction between duration, level of activity and frequency & \\
barticipants' assessment of physical nature of employment & &
\end{tabular}

All determinants with a $p$-value $<0.10$ in the univariate Cox regression were included in the multivariate Cox regression: osteoporosis, age $>60$ years, a previous fracture, alcohol intake $>2$ glasses per week, and current smoking. The multivariate Cox regression for the total group found that a previous fracture (HR: 2.6, Cl: 2.1-3.3), osteoporosis (T-score $\leq-2.5)$ (HR: 1.4, Cl: 1.1$1.8)$ and age $>60$ years (HR: $1.3, \mathrm{Cl}: 1.0-1.6)$ were significant independent 
predictors $(p<0.05)$ of an incident clinical fracture. Significant interaction was found between a previous fracture and osteoporosis, indicating that osteoporosis contributed only as a predictor for the first and not for the second fracture.

The only retained risk factors for a first fracture were osteoporosis (HR: $1.8, \mathrm{Cl}$ : 1.4-2.3), followed by age $>60$ years (HR: 1.4, Cl: 1.1-1.8). These determinants were used to construct an algorithm (Figures 2 and 3). The only retained risk factor for a second fracture was the time that had elapsed since the first fracture. As Figures 2 and 3 show, more than $40 \%$ of the women with a fracture during the past five years $(n=184)$ had a new clinical fracture during the followup period, compared with $25.1 \%$ in women in whom the fracture had occurred earlier ( $n=154$; HR: 1.8, Cl: 1.3-2.7).

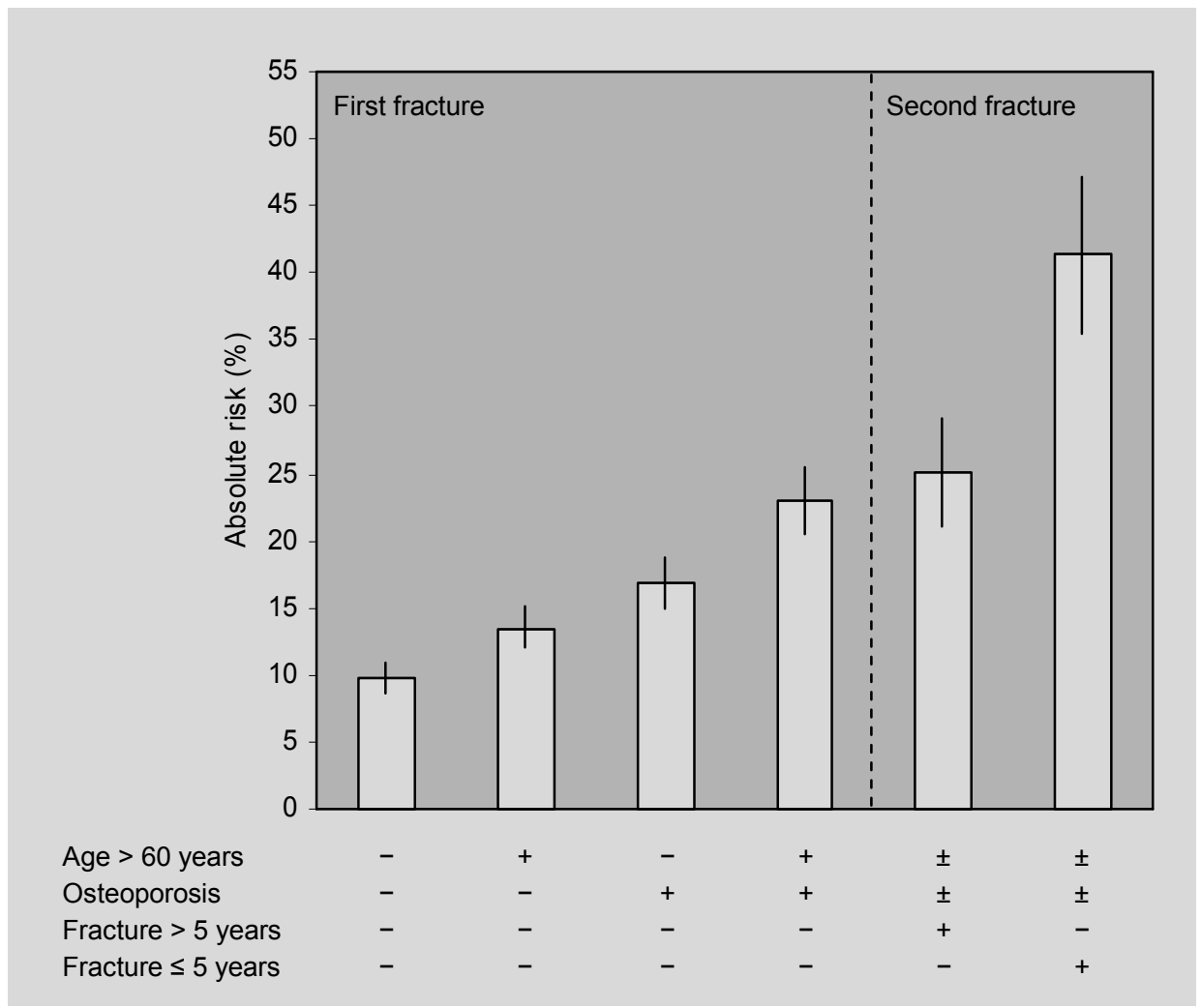

Figure 3 Absolute risk for any clinical fracture per fracture risk category. First four categories are based on women without a fracture history $(n=2029)$; last two categories are based on women with a fracture history $(n=338)$.

- risk factor not present; + risk factor present; \pm risk factor not necessarily present. 


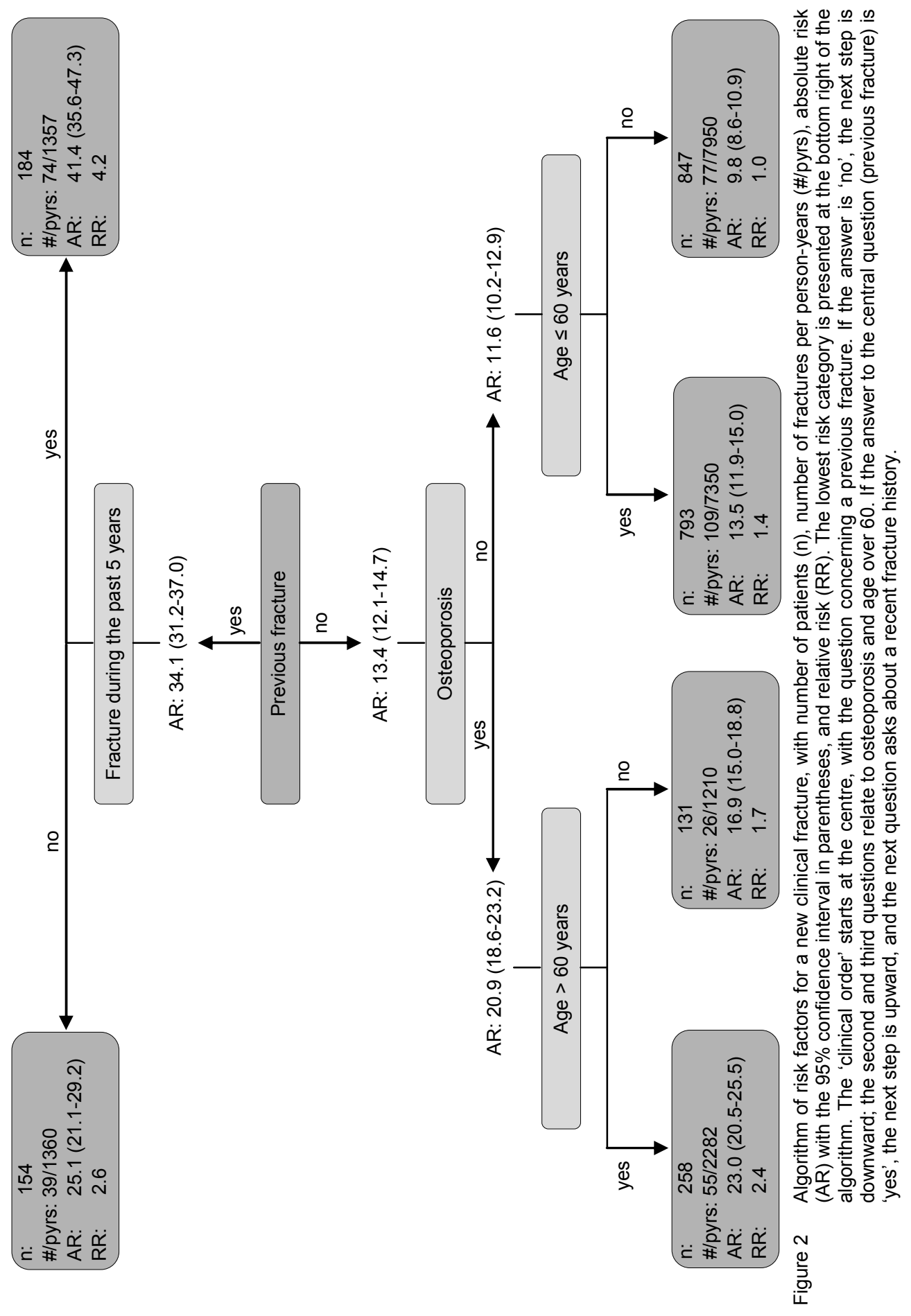




\section{Discussion}

In postmenopausal women, over a 10-year period, the AR of any clinical fracture is highest within the five years after any clinical fracture. Other risk factors made no further contributions when the time factor was considered in women with a history of fracture after menopause. The AR for a first clinical fracture was much lower and depended on osteoporosis and being over 60 years of age.

This is one of the few studies to investigate the 10-year AR of all clinical fractures while taking account of the time that elapses between a first and second fracture. It confirmed the main outcome of our five-year follow-up study, ${ }^{14}$ which was that clinical fractures cluster in time. The present study, though, includes four times as many fractures, three times as many participants, and a follow-up period which is twice as long.

The significant determinants for a new clinical fracture in our study have been investigated before, leading to partly comparable results. ${ }^{6-17,23,24} \mathrm{~A}$ large metaanalysis reported an HR of 2.0 for fracture history. ${ }^{23}$ However, limited data are available about the absolute fracture risk in relation to time that elapses between a fracture after baseline and a previous fracture. ${ }^{13-17}$ As shown above, our study confirmed the role of fracture history in predicting incident clinical fractures. The significance of the time that elapsed between a first and second fracture has also been observed after morphometric vertebral fractures, as, within one year of such a fracture, $19 \%$ of postmenopausal women with osteoporosis developed an identical one. ${ }^{13}$ Other studies showed that fracture risk is highest immediately after a fracture: $34 \%{ }^{16}$ during the first year, and $12 \%{ }^{17}$ and approximately $41 \%{ }^{15}$ during the first two years.

Age has been documented as a risk factor for fractures in several studies, independent of BMD. ${ }^{24}$ Our study found comparable results, even though we studied a relatively young population with only $12.5 \%$ over the age of 70 years, whereas women included in other studies were aged 65 years and over. ${ }^{6,9,11}$ Many factors that change with age have been proposed to be involved, such as skeletal factors (bone turnover, mineralisation, matrix collagen quality, repair) and non-skeletal factors (risk of falling).

Apart from age, osteoporosis was the strongest determinant of a new clinical fracture in women without a previous fracture. Measuring BMD in all postmenopausal women without a previous fracture is inefficient, because this subgroup accounts for $85.5 \%$ of our total population. However, there are 
screening tools available which can be used to increase the efficiency of selection for BMD screening. ${ }^{18,25}$

Our study was subject to several limitations. At baseline (1992-94), no BMD measurements at the hip were performed, owing to a lack of funding. Instead, the BMD measurements at baseline were performed at the lumbar spine. In elderly women, these measurements could have been influenced by the presence of osteoarthritis. Furthermore, 134 women $(5.6 \%)$ might have improved their lifestyle, since they were given information about calcium intake and exercise after baseline measurements had been completed. However, media publicity, which women often act on, offers the same advice. These 134 women were also treated for osteoporosis. Excluding these participants did not change the results. A further limitation was that only clinical vertebral fractures were used. Morphometric vertebral fractures significantly increase the risk of a new clinical fracture ${ }^{13}$ and therefore our results might have been different if the morphometric fractures had also been taken into account. Finally, there was no validation of negative reports. Hence, the number of new clinical fractures could be an underestimation. The assumption was made that women would remember a traumatic experience such as a fracture.

\section{Conclusion}

A fracture during the past five years is relevant for identifying postmenopausal women at high risk, since more than $40 \%$ of the women with a recent previous fracture had a new clinical fracture. These conclusions are important to a variety of professionals. Policymakers can use the algorithm presented here for fracture prevention strategies, and GPs and hospital specialists can detect quickly and accurately which postmenopausal women are at high risk. When postmenopausal women are at high risk, appropriate fracture prevention strategies, which have been shown to decrease the risk of fractures in the short term, must be initiated. 


\section{References}

1. Schuit SCE, Klift van der M, Weel AEAM, et al. Fracture incidence and association with bone mineral density in elderly men and women: the Rotterdam Study. Bone 2004; 34: 195-202.

2. Woolf AD, Akesson K. Preventing fractures in elderly people. BMJ 2003; 327(7406): 89-95.

3. Delmas PD, Fraser M. Strong bones in later life: luxury or necessity? Bull World Health Organ 1999; 77(5): 416-22.

4. Kanis JA, Johnell O. Requirements for DXA for the management of osteoporosis in Europe. Osteoporos Int 2005; 16(3): 229-38.

5. Kanis JA, Borgstrom F, De Laet C, et al. Assessment of fracture risk. Osteoporos Int 2005; 16(6): 581-9.

6. Black DM, Steinbuch M, Palermo L, et al. An assessment tool for predicting fracture risk in postmenopausal women. Osteoporos Int 2001; 12(7): 519-28.

7. Burger $\mathrm{H}$, De Laet CE, Weel AEAM, et al. Added value of bone mineral density in hip fracture risk scores. Bone 1999; 25(3): 369-74.

8. Klift van der M, Laet de CEDH, McCloskey EV, et al. Risk factors for incident vertebral fractures in men and women: the Rotterdam Study. J Bone Miner Res 2004; 19(7): 1172-80.

9. McGrother CW, Donaldson MM, Clayton D, et al. Evaluation of a hip fracture risk score for assessing elderly women: the Melton Osteoporotic Fracture (MOF) study. Osteoporos Int 2002; 13(1): 89-96.

10. Miller PD, Barlas S, Brenneman SK, et al. An approach to identifying osteopenic women at increased short-term risk of fracture. Arch Intern Med 2004; 164(10): 1113-20.

11. Nguyen ND, Pongchaiyakul C, Center JR, et al. Identification of high-risk individuals for hip fracture: a 14-year prospective study. J Bone Mineral Res 2005; 20(11): 1921-8.

12. Siris ES, Miller PD, Barrett-Connor $E$, et al. Identification and fracture outcomes of undiagnosed low bone mineral density in postmenopausal women: results from the National Osteoporosis Risk Assessment. JAMA 2001; 286(22): 2815-22.

13. Lindsay RL, Silverman SL, Cooper C, et al. Risk of new vertebral fracture in the year following a fracture. JAMA 2001; 285(3): 320-3.

14. Geel van ACM, Geusens $P$, Nagtzaam IF, et al. Timing and risk factors of clinical fractures among postmenopausal women: A 5-year prospective study. BMC Med 2006; 4(24).

15. Center JR, Bliuc D, Nguyen TV, et al. Risk of subsequent fracture after low-trauma fracture in men and women. JAMA 2007; 297(4): 387-94.

16. Johnell O, Kanis JA, Oden A, et al. Fracture risk following an osteoporotic fracture. Osteoporos Int 2004; 15(3): 175-9.

17. Helden van $\mathrm{S}$, Cals J, Kessels $\mathrm{F}$, et al. Risk of new clinical fractures within 2 years following a fracture. Osteoporos Int 2006; 17(3): 348-54.

18. Voort van der DJM, Dinant GJ, Rinkens PELM, et al. Construction of an algorithm for quick detection of patients with low bone mineral density and its applicability in daily general practice. J Clin Epidemiol 2000; 53: 1095-103.

19. Voort van der DJM, Geusens PP, Dinant GJ. Risk factors for osteoporosis related to their outcome: fractures. Osteoporos Int 2001; 12: 630-8.

20. Joakimsen RM, Fonnebo V, Sogaard AJ, et al. The Tromso study: registration of fractures, how good are self-reports, a computerized radiographic register and a discharge register? Osteoporos Int 2001; 12(12): 1001-5.

21. Geusens PP. Review of guidelines for testing and treatment of osteoporosis. Curr Osteoporos Rep 2003; 1(2): 59-65. 
22. Gezondheidsraad. Voedingsnormen: calcium, vitamine $D$, thiamine, riboflavine, niacine, pantotheenzuur en biotine. Vol. 2000/12. 2000, Den Haag. 180.

23. Klotzbuecher CM, Ross PD, Landsman PB, et al. Patients with prior fractures have an increased risk of future fractures: a summary of the literature and statistical synthesis. J Bone Miner Res 2000; 15(4): 721-7.

24. Kanis JA, Johnell O, Oden A, et al. Ten year probabilities of osteoporotic fractures according to BMD and diagnostic thresholds. Osteoporos Int 2001; 12(12): 989-95.

25. Geusens P, Hochberg MC, Voort van der DJM, et al. Performance of risk indices for identifying low bone density in postmenopausal women. Mayo Clin proc 2002; 77(7): 629-37. 


\section{Chapter 4}

\section{Clinical fractures cluster in time in women from menopause onwards}

Tineke van Geel, Svenhjalmar van Helden, Piet Geusens, Bjorn Winkens and Geert-Jan Dinant

Published as: Clinical subsequent fractures cluster in time after first fractures. Ann Rheum Dis. Published Online First: 03 August 2008.

doi: 10.1136/ard.2008.092775 


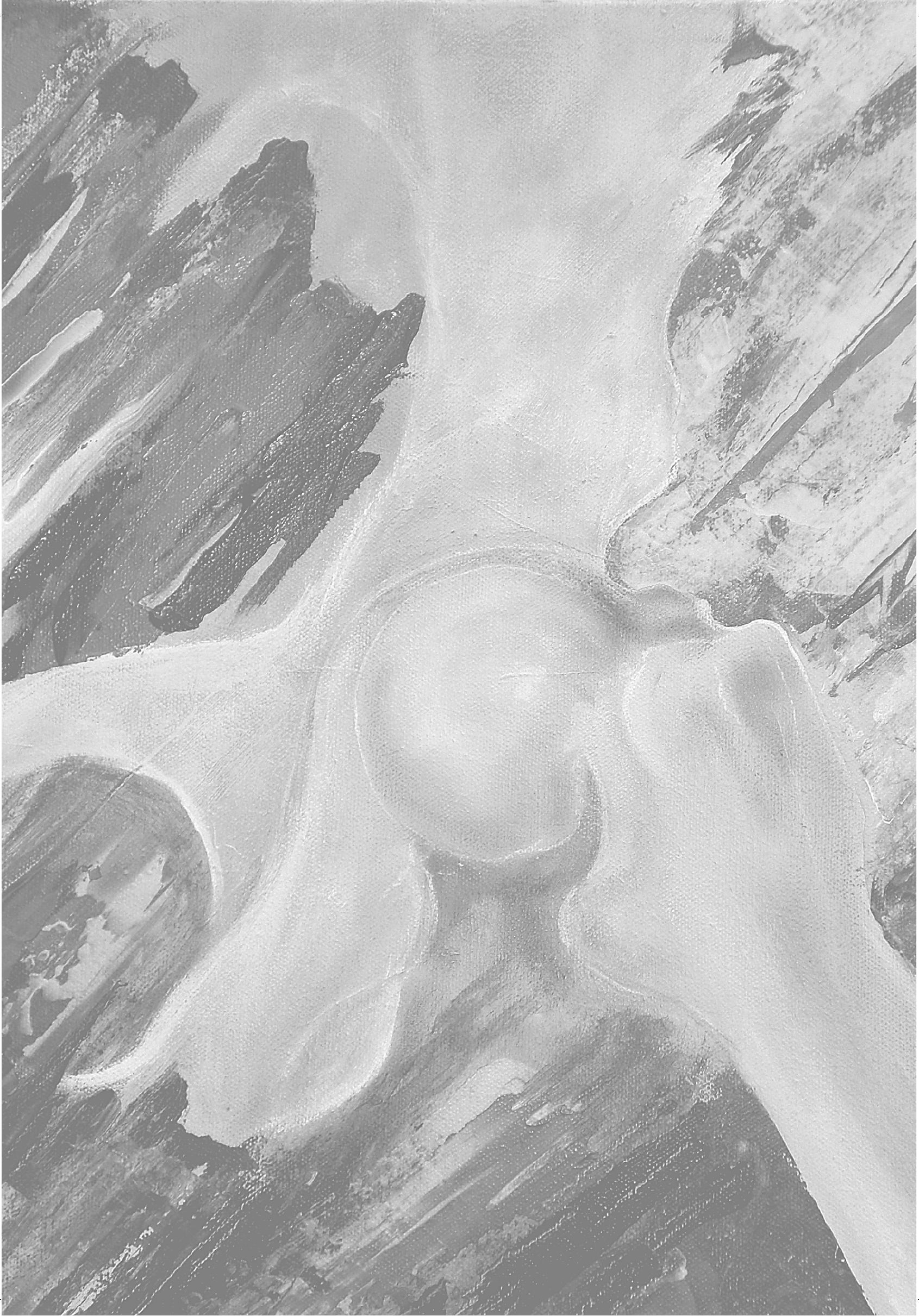




\section{Abstract}

\section{Introduction}

The risk of subsequent fractures is double the risk of having a first fracture. We therefore analysed the time relation between first and subsequent clinical vertebral and non-vertebral fractures.

\section{Methods}

A population-based study in 4203 postmenopausal women, aged between 50 and 90 years, who completed questionnaires about the locations and times of radiographic confirmed clinical fractures from menopause onwards. Absolute risks, relative risks (RR) and the percentage of all first and of all subsequent fractures were calculated over time, using Cox regression, with 95\% confidence intervals $(\mathrm{Cls})$.

\section{Results}

Up to 45 years after the onset of menopause, $924(22 \%)$ women had a first fracture and $243(26 \%$ of 924$)$ a subsequent fracture. Twenty-three percent of all subsequent fractures occurred within one year after the first fracture and $54 \%$ within 5 years, while $4 \%$ of all first fractures occurred in each of the years from menopause onwards.

The RR of subsequent fracture over the whole follow-up period was twice the risk of a first fracture (RR: 2.1, Cl: 1.7-2.6), 5.3 (Cl: 4.0-6.6) during the first year after the first fracture, 2.8 ( $\mathrm{Cl}: 2.0-3.6)$ from 2 to 5 years after the first fracture and $0.7(\mathrm{Cl}: 0.5-1.0)$ more than 6 years after the first fracture.

\section{Conclusion}

From menopause onwards, clinical vertebral and non-vertebral fractures cluster in time. One in four of all subsequent (second) fractures occurred within 1 year after a first fracture and half within 5 years, indicating the need for early action after a first fracture to prevent subsequent fractures. 


\section{Introduction}

$\mathrm{M}$ any studies have shown that a history of fracture after the age of $45-50$ years is associated with a doubling of the risk of a new fracture, the risk being even higher after a vertebral fracture. ${ }^{1}$ Although some studies found a recent history of fracture to be a greater risk factor for subsequent fracture than an earlier fracture history, ${ }^{2-5}$ most of these were studies of short-term fracture risk prediction, ${ }^{3,4}$ for selected subgroups of fractures ${ }^{4,5}$ or for low-trauma fractures in women and men older than 60 years. ${ }^{6}$ Lindsay et al. ${ }^{4}$ found new fractures occurring soon after morphometric vertebral fractures in a study involving a 3-year follow-up period, with almost $20 \%$ of patients with an incident morphometric vertebral fracture developing a new morphometric vertebral fracture within one year. Johnell et al. $^{5}$ showed that the relative risk of subsequent (i.e. second) fractures at specific locations (vertebra, humerus and hip) is highest in the first year after a first fracture at the same location. In addition, they found an incidence of $12 \%$ for these subsequent fractures over a 2-year period, ${ }^{5}$ which was similar to that reported for all patients presenting with any clinical vertebral or non-vertebral fracture. ${ }^{3}$ Our own previous studies found that 1 out of 2 postmenopausal women having sustained a fracture during the past 5 years had a subsequent clinical fracture within 5 years, and 2 out of 5 women had one within 10 years, regardless of bone mineral density of the spine. ${ }^{2,7}$

Since these studies suggested clustering of certain fractures in time, we analysed the time that elapses between a first and subsequent clinical vertebral and non-vertebral fracture in a long-term study from menopause onwards, including low- and high-trauma fractures. If the time that elapses between the first and subsequent fractures from the onset of menopause is indeed short, the clinical consequence is that after menopause, immediate action should be taken to prevent subsequent fractures after a first fracture.

\section{Methods}

\section{Participants}

In a cross-sectional population-based study (1992-94), 4203 postmenopausal women aged 50 to 80 years completed a questionnaire about fracture history and onset of menopause. The methodology of this study has been described in detail elsewhere. . $^{-11}$ 


\section{Measurements}

The 4203 women were prospectively followed. Five and ten years after the 1992-94 assessment, the women received questionnaires about their history of clinical vertebral and non-vertebral fractures since menopause, including location in the body, circumstances of the event that resulted in the fracture, and the year of occurrence. Low-trauma fractures were defined as fractures sustained from standing height or less. ${ }^{6}$ All reported fractures were checked by a research nurse and were confirmed on X-rays.

\section{Statistical analysis}

We based our analysis on methods similar to those used by Center et al. in a study among women and men older than 60 years. $^{6}$

Incidence rates for a first fracture were calculated as the annual incidence from the start of menopause. Once a person had sustained a fracture, she was excluded from the population at risk for first fracture. Only first fractures occurring since menopause were considered in this analysis. In the re-fracture analysis, time to subsequent fracture was calculated as the time between the first and the next clinical fracture. For those who did not sustain a first or subsequent fracture, follow-up time was calculated as time to either death or the end of the study period. Cox regression proportional hazards models were used for the statistical analyses, taking into account the fracture and death hazard.

First, the absolute risks (AR) for first and subsequent fractures were calculated. The ARs were calculated for all clinical vertebral and non-vertebral fractures combined, as well as separate risks for those resulting from a low trauma.

Second, relative risks (RR) with 95\% confidence intervals $(\mathrm{Cl})$ of subsequent fractures compared with first fracture during follow-up were calculated for intervals of $0-1,0-5,0-10$ and $0-20$ or more years after the first fracture, as well as for intervals of 2-5 years and $>6$ years after the first fracture, and for 10-year intervals after the first fracture.

Third, we calculated the percentages of all first fractures that occurred within various periods of time from the onset of menopause, as well as the percentages of all subsequent fractures that occurred within various periods of time after the first fracture. The best-fitting regression line between the percentage of all fractures and the number of years of follow-up was constructed for first fractures (from menopause onwards) and subsequent fractures (from the time of the first fracture), based on the $R^{2}$ regression coefficient. 
Fourth, the risk of subsequent fractures was analysed according to age and first fracture location. First fractures were classified according to the broad groups used by the World Health Organisation ${ }^{12}$ into hip, major (clinical vertebral, forearm, humerus) and minor (other) fractures.

SPSS software (version 15.0; SPSS Inc. Chicago, IL, USA) was used for the statistical analyses.

\section{Ethics}

The Medical Ethics Committee of Maastricht University and the Maastricht University Hospital approved the study (reference number: MEC 94-196.1).

\section{Results}

A total of 4140 postmenopausal women with a known fracture history $(98.5 \%$ of the total population of the $1992-94$ cross-sectional study $(n=4203))$ participated in the present study (Figure 1). The calculated drop-out rate was $1.6 \%$ per year, and resulted from death or non-participation by participants or GPs.

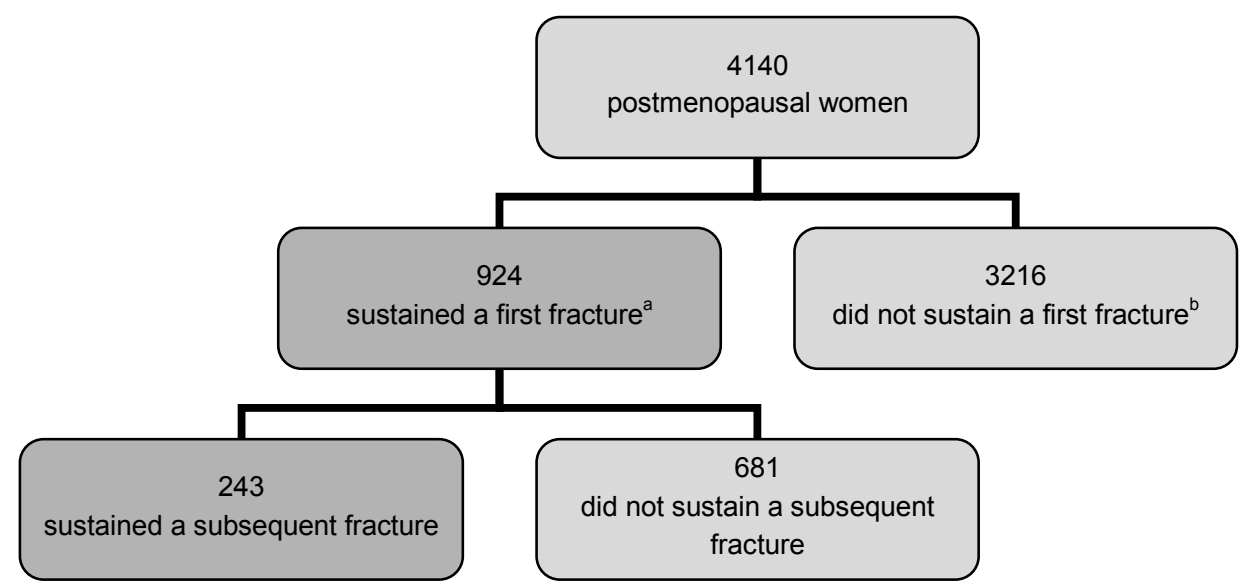

Figure 1 Flow-chart of patient inclusion.

a 785 first low-trauma fractures and 139 first high-trauma fractures

${ }^{\mathrm{b}}$ Includes those lost to follow-up (estimated drop-out rate of $1.6 \%$ per year) 


\section{Absolute risk of first or subsequent fracture}

Of the 4140 women in the study, 924 (22.3\%) sustained a first fracture after the onset of menopause. (Figure 1, Table 1). The maximum duration of follow-up after the onset of menopause till the first fracture or the end of the study was 45 years, with a mean of 19.2 years (standard deviation (SD): 9.3) and included 79620 person-years.

The AR for a first fracture during one year of follow-up after the onset of menopause was $1.0 \%$ (95\% confidence interval $(\mathrm{Cl}): 0.7-1.3)$. The AR remained constant over time, resulting in a $19.0 \%(\mathrm{Cl}: 17.6-20.3)$ AR over a period of 20 years (Table 2$)$ and a $50.8 \%(\mathrm{Cl}: 44.4-57.3)$ AR over 45 years.

Table 1 Relation between the incidence of first and subsequent hip, major and minor fractures; ${ }^{a}$ percentages between brackets.

\begin{tabular}{|c|c|c|c|c|c|}
\hline & & \multicolumn{3}{|c|}{ Site of subsequent fracture $(n=243)$} & \multirow[b]{2}{*}{ Total } \\
\hline & & Hip & Major & Minor & \\
\hline \multirow{3}{*}{$\begin{array}{l}\text { Site of first } \\
\text { fracture } \\
(\mathrm{n}=924)\end{array}$} & $\operatorname{Hip}(n=115,12.4 \%)$ & $6(5)$ & $17(15)$ & $14(12)$ & $37(32)$ \\
\hline & Major $(n=417,45.1 \%)$ & $11(3)$ & $75(18)$ & $32(8)$ & $118(28)$ \\
\hline & Minor $(n=392,42.4 \%)$ & $6(2)$ & $39(10)$ & $43(11)$ & $88(22)$ \\
\hline & Total & $23(2)$ & $131(14)$ & $89(10)$ & $243(26)$ \\
\hline
\end{tabular}

a Fracture sites: hip, major (clinical vertebral, forearm, humerus) and minor (others)

Of the 924 women with a first fracture, $243(26.3 \%)$ sustained a subsequent fracture (Table 1). The maximum time that elapsed between the first fracture and the subsequent fracture or the end of the study was 40 years, with a mean of 8.9 years (SD: 7.6 years), and included 8181 person-years.

The one-year $A R$ for subsequent fracture during the first year after the first fracture was $6.1 \%(\mathrm{Cl}: 4.5-7.6)$ and decreased exponentially, resulting in an AR for subsequent fracture of $40.2 \%$ (35.4-45.0) over a 20 -year period (Table 2).

Similar results were found when taking into account only the first low-trauma, clinical, vertebral or non-vertebral fracture $(n=785,85.0 \%$ of all fractures), instead of all first clinical fractures (Table 2). 
Table 2 Absolute risk and percentages (\%) of first fractures, subsequent fractures, and subsequent fractures occurring at various times after first low-trauma fracture, with $95 \%$ confidence intervals $(\mathrm{Cl})$.

\begin{tabular}{|c|c|c|c|}
\hline & \multicolumn{3}{|c|}{ First fracture } \\
\hline $\begin{array}{c}\text { Years from } \\
\text { menopause } \\
\text { onwards }\end{array}$ & $\begin{array}{c}\text { No. of first fractures } \\
\text { from menopause } \\
\text { onwards }\end{array}$ & $\begin{array}{l}\text { Absolute risk (Cl) } \\
\qquad(\mathrm{n}=4140)\end{array}$ & $\begin{array}{l}\% \text { of all first fractures from } \\
\text { menopause onwards }(\mathrm{Cl}) \\
(\mathrm{n}=924)\end{array}$ \\
\hline $0-1$ & 40 & $1.0 \quad(0.7-1.3)$ & $4.3 \quad(3.0-5.6)$ \\
\hline $0-5$ & 143 & $3.5 \quad(3.0-4.1)$ & $15.5 \quad(13.2-17.8)$ \\
\hline $0-10$ & 313 & $7.9 \quad(7.1-8.7)$ & $33.9 \quad(30.9-36.9)$ \\
\hline $0-15$ & 498 & $13.2(12.2-14.3)$ & $53.9 \quad(50.8-57.0)$ \\
\hline $0-20$ & 655 & $19.0 \quad(17.6-20.3)$ & 70.9 (68.1-73.7) \\
\hline \multicolumn{4}{|l|}{ Interval } \\
\hline $0-1$ & 40 & $1.0 \quad(0.7-1.3)$ & $4.3 \quad(3.0-5.6)$ \\
\hline $2-5$ & 103 & $2.5 \quad(2.1-3.0)$ & $11.1 \quad(9.2-13.1)$ \\
\hline $6-10$ & 170 & $4.4 \quad(3.8-5.0)$ & $18.4(16.0-20.8)$ \\
\hline $11-15$ & 185 & $5.3 \quad(4.7-6.0)$ & $20.0 \quad(17.5-22.3)$ \\
\hline $16-20$ & 157 & $5.7 \quad(5.0-6.4)$ & $17.0 \quad(14.8-19.2)$ \\
\hline & \multicolumn{3}{|c|}{ Subsequent fracture } \\
\hline $\begin{array}{l}\text { Years from } \\
\text { first fracture } \\
\text { onwards }\end{array}$ & $\begin{array}{l}\text { No. of subsequent } \\
\text { fractures from first } \\
\text { fracture onwards }\end{array}$ & $\begin{array}{l}\text { Absolute risk }(\mathrm{Cl}) \\
\qquad(\mathrm{n}=924)\end{array}$ & $\begin{array}{l}\% \text { of all subsequent } \\
\text { fractures from first fracture } \\
\text { onwards }(\mathrm{Cl})(n=243)\end{array}$ \\
\hline $0-1$ & 56 & $6.1 \quad(4.5-7.6)$ & $23.0 \quad(18.1-28.0)$ \\
\hline $0-5$ & 132 & $15.9 \quad(13.4-18.4)$ & $54.3 \quad(48.5-60.2)$ \\
\hline $0-10$ & 195 & $27.1 \quad(23.8-30.5)$ & $80.2 \quad(75.6-84.9)$ \\
\hline $0-15$ & 223 & $35.7 \quad(31.5-39.8)$ & $91.8 \quad(88.6-94.9)$ \\
\hline $0-20$ & 232 & $40.2 \quad(35.4-45.0)$ & $95.5 \quad(93.1-97.9)$ \\
\hline \multicolumn{4}{|l|}{ Interval } \\
\hline $0-1$ & 56 & $6.1 \quad(4.5-7.6)$ & $23.0 \quad(18.1-28.0)$ \\
\hline $2-5$ & 76 & $9.8 \quad(7.9-11.8)$ & $31.3 \quad(25.8-36.8)$ \\
\hline $6-10$ & 63 & $11.2 \quad(9.2-13.3)$ & $25.9 \quad(20.8-31.1)$ \\
\hline $11-15$ & 28 & $8.5 \quad(6.7-10.4)$ & $11.5(9.5-13.5)$ \\
\hline $16-20$ & 9 & $4.5 \quad(3.4-5.7)$ & $3.7 \quad(3.1-4.4)$ \\
\hline & \multicolumn{3}{|c|}{ Subsequent fracture - based on low-trauma first fracture } \\
\hline $\begin{array}{l}\text { Years from } \\
\text { first fracture } \\
\text { onwards } \\
\end{array}$ & $\begin{array}{l}\text { No. of subsequent } \\
\text { fractures from first } \\
\text { fracture onwards }\end{array}$ & $\begin{array}{l}\text { Absolute risk }(\mathrm{Cl}) \\
\quad(\mathrm{n}=785)\end{array}$ & $\begin{array}{l}\% \text { of all subsequent } \\
\text { fractures from first fracture } \\
\text { onwards }(\mathrm{Cl})(n=211)\end{array}$ \\
\hline $0-1$ & 49 & $6.4 \quad(4.7-8.1)$ & $23.2(18.0-28.5)$ \\
\hline $0-5$ & 116 & $16.7 \quad(13.9-19.4)$ & $55.0 \quad(48.7-61.2)$ \\
\hline $0-10$ & 169 & $27.9 \quad(24.2-31.6)$ & $80.1 \quad(75.1-85.1)$ \\
\hline $0-15$ & 196 & $37.5 \quad(32.9-42.2)$ & $92.9(89.8-96.0)$ \\
\hline $0-20$ & 204 & $42.5 \quad(37.1-47.9)$ & $96.7 \quad(94.5-98.9)$ \\
\hline
\end{tabular}




\section{Relative risks and percentage of all first or subsequent fractures occurring in various periods}

The RR of subsequent fracture over the entire follow-up period was 2.1 (Cl: 1.72.6, Figure 2) compared with the risk of a first fracture. The RR of a subsequent fracture was highest in the first year after the first fracture (RR: 5.3, Cl: 4.0-6.6) and remained significantly elevated during 15 years of follow-up (RR: 1.7, Cl: 1.2-2.2, Figure 3).

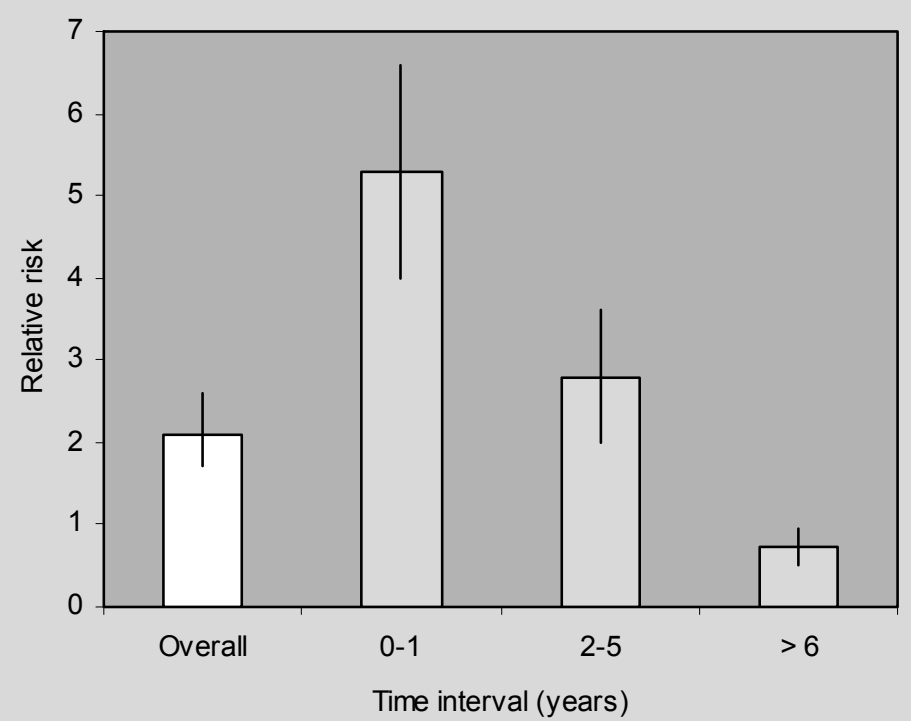

Figure 2 Relative risks with 95\% confidence intervals: comparison of first and subsequent fractures during the overall follow-up period and for specific time intervals.

Compared with the risk of a first fracture, the RR for the specific intervals of $0-1$, 2-5 and >6 years was highest in the first year (RR: 5.3, Cl: 4.0-6.6) and remained significantly elevated during the 2-5 year interval after the first fracture (RR: 2.8, Cl: 2.0-3.6), but not for the period > 6 years after the first fracture (RR: $0.7, \mathrm{Cl}: 0.5-1.0$, Figure 2). Furthermore, the 10-year RR of a subsequent fracture after a first fracture was significantly higher than the 10-year risk of a first fracture from menopause onwards (RR: 2.4, Cl: 1.7-3.1), one year after the first fracture (RR: 1.8, Cl: 1.2-2.3) and 2 years after the first fracture (RR: 1.6, $\mathrm{Cl}: 1.1-2.1)$ but not from the third year after the first fracture onwards (RR: 1.3, $\mathrm{Cl}: 0.9-1.6)$. 
Of all first fractures, $4.3 \%(\mathrm{Cl}: 3.0-5.6)$ occurred in each of the years from the onset of menopause onwards. This fracture incidence remained constant over time, as the best-fitting regression was linear $\left(R^{2}=0.998\right.$ compared with $\mathrm{R}^{2}=0.900$ for an exponential). Of all subsequent fractures, $23.0 \%$ (Cl: 18.128.0) occurred in the first year after the first fracture, $31.3 \%(\mathrm{Cl}: 25.8-36.8)$ in the next four years and $25.9 \%$ (Cl: 20.8-31.1) during the next five years (i.e. 610 years after the first fracture) (Table 2). This percentage decreased exponentially over time, as the best-fitting regression was exponential $\left(R^{2}=0.996\right.$ compared with $R^{2}=0.884$ for a linear $)$.

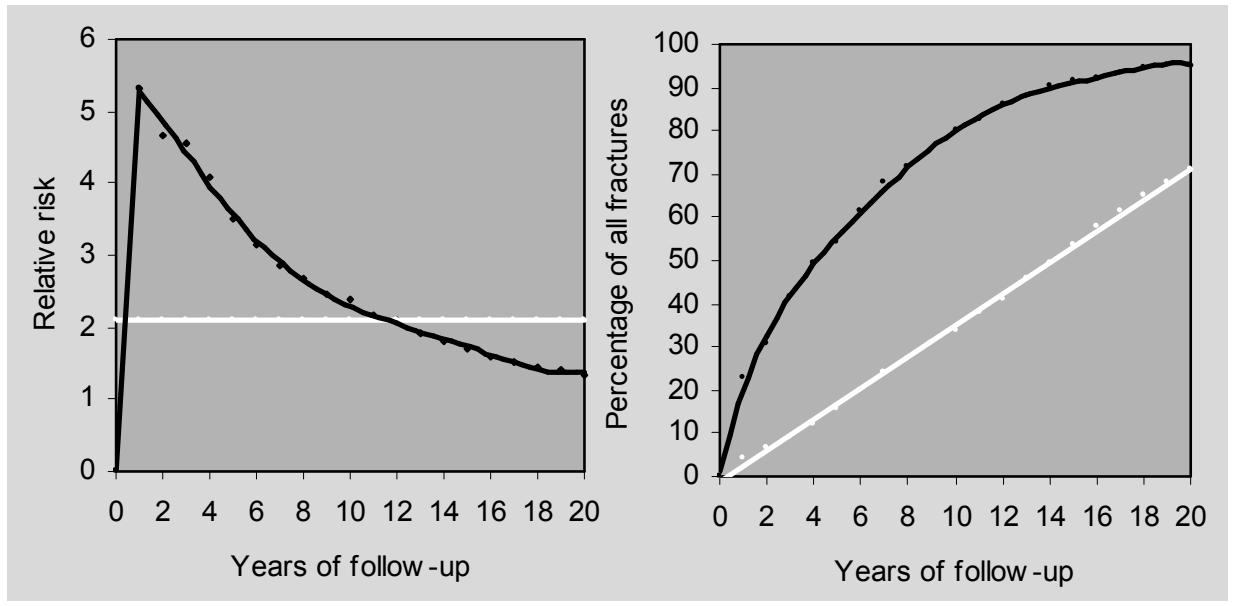

Figure 3 Relative risk (left figure) of all subsequent fractures calculated as a mean from the first fracture (white line) or per separate year of follow-up (black line); and percentage (right figure) of all first (white line) and subsequent (black line) fractures.

\section{Effect of age and first fracture location on subsequent fracture risk}

Women who sustained their first fracture aged $>60$ years $(n=134)$ sustained their subsequent fracture significantly earlier than women who were younger than 60 at the time of the first fracture $(n=109$, hazard ratio $(H R): 1.4$, Cl: 1.1-1.8). 


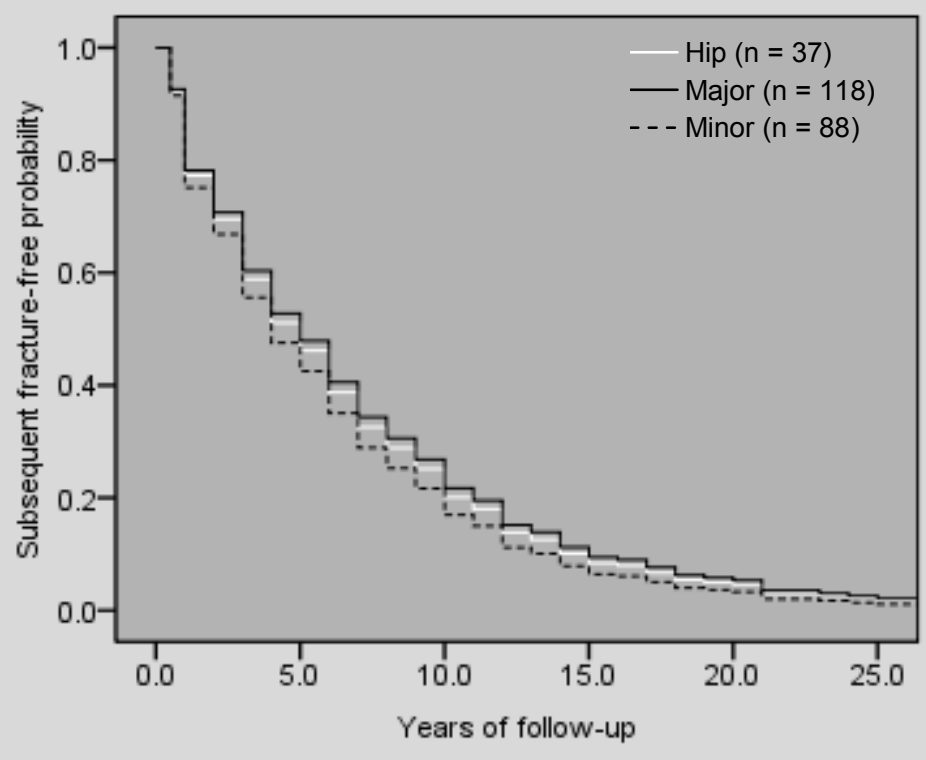

Figure 4 Percentage of all subsequent fractures $(n=243)$ occurring at various times, based on location of first fracture (hip, major (clinical vertebral, forearm, humerus) and minor (others)).

Table 1 shows the relation between the incidence of first and subsequent of hip, major and minor fractures. The incidence in percent of patients with subsequent hip or major fractures was higher after a hip fracture $(20 \%)$ or major fracture $(21 \%)$ than after a minor first fracture $(12 \%)$. However, in number of patients with new fractures, more patients with a first major or minor fracture had a new hip or major fracture than after a first hip fracture (86, 45 and 23 , respectively). Subsequent fracture risk was similar in patients whose first fracture was a hip fracture $(n=37)$ or a major $(n=118)$ or a minor fracture $(n=88$, Figure 4$)$.

\section{Discussion}

In this prospective long-term study we have demonstrated that clinical vertebral and non-vertebral fractures cluster in time from menopause onwards. Twentythree percent of the subsequent (second) fractures occurred within one year after the first fracture, and $54.3 \%$ occurred within five years. The AR for a first fracture over a period of 45 years was $50.8 \%$ (Cl: $44.4-57.3)$ which is close to the lifetime risk of $53.2 \%$ for women aged 50 years and over. ${ }^{13}$ 
Few studies have investigated the time that elapses between the first and subsequent clinical fractures. ${ }^{3-5}$ In a study over a period of three years, Lindsay et al. ${ }^{4}$ found that $19.2 \%$ of all women with an incident morphometric vertebral fracture had a subsequent morphometric vertebral fracture within one year. However, two out of three of such fractures occur without the clinical signs and symptoms of an acute fracture. ${ }^{4}$ Johnell et al. ${ }^{5}$ also documented a higher risk for subsequent fractures immediately after a first osteoporotic fracture, but their study was limited to fractures of the hip, humerus and vertebrae. ${ }^{5}$ Center et al. ${ }^{6}$ studied a population of women and men older than 60 years, and reported that the additional risk for subsequent fractures decreased over time after the first fracture. They also found that after 10 years of follow-up, the subsequent fracture risk was no longer significantly higher than the risk for individuals without previous fractures $(41 \%$ of the subsequent fractures occurred within two years). Center et al. showed that women aged over 60 years were at higher risk for a first fracture than women aged below 60 . Our results from a previous study confirm this, as we found a significantly lower AR for a first fracture in women aged 60 years and younger $(10.7 \%(\mathrm{Cl}: 9.5-12.0))$ than in women aged over 60 (15.8\% (Cl: 14.0-17.6)). ${ }^{7}$ Our current results extend the above observations to all clinical vertebral and non-vertebral fractures, in women from menopause onwards, and for both low- and high-trauma fractures. A finding of clinical importance was that even if the first fracture was a minor one, the risk of a subsequent fracture was similar to that after hip or major fractures. In addition, the subsequent fracture after such a minor fracture was not limited to minor ones, but could be a hip or other major fracture.

Klotzbuecher et al. ${ }^{1}$ calculated pooled RRs of between 1.8 and 2.0 for all fracture categories from studies in perimenopausal/postmenopausal women. ${ }^{1}$ These authors, as well as the developers of the new WHO algorithm, ${ }^{12,} 14$ indicated that risks could wane off over time. We found that the RR immediately fluctuates after a fracture thus the long-term $R R$ of two is driven by the high short-term RR (Figure 3).

For clinical reasons, the ARs, percentages of fractures occurring in various periods and RRs were not only calculated for the time intervals from the onset of menopause onwards and from the time of the first fracture onwards $(0-1,0-5$, $0-10,0-15$ and $0-20$ years), but also for specific time intervals $(0-1,2-5,6-10$, $11-15$ and $>20$ years). This distinction has clinical consequences. For example, for patients presenting immediately after a recent first fracture, it is possible to calculate the risk of subsequent fracture after one, five, ten years, or the lifetime risk. We found that the risk of such a subsequent fracture is highest during the first year and remains elevated for the next 15 years. However, if a woman does 
not seek medical attention immediately after her first fracture but later, the absolute subsequent fracture risks, percentages of fractures occurring in various periods and relative risks over the next years will be lower, as many subsequent fractures may already have occurred. For example, the risk of subsequent fractures is no longer higher than the first fracture risk from six years on after the first fracture, as more than $50 \%$ of women with a subsequent fracture had their subsequent fracture within the first five years after the first fracture. This fluctuation, and the five-fold increase within the first year, might be caused by falls and fall-related risks increase the subsequent fracture risk after a first fracture, because it is unclear how bone-related risks alone could increase the clustering in time. A study by van Helden et al. ${ }^{15}$ showed that patients with an early subsequent fracture after the first fractures were recurrent fallers. Recurrent falls might be caused by immobility (due to plasters, bed rest) and vitamin $\mathrm{D}$ deficiency amongst others. ${ }^{15,16}$

Our study had several limitations. First, 271 of the women $(6.4 \%$, mean number of years of use $=4.6$; $S D=3.7$ years) received bisphosphonates after the baseline assessment. However, excluding these women from the analysis did not change the results (data not shown). Second, only the fractures reported by the patients were confirmed in the medical files, and there was no validation of the negative reports. However, a study by Ismail et al. ${ }^{17}$ assessed the validity of self-reported incidence of non-spinal fractures using a postal questionnaire and concluded that this method produced accurate information about the occurrence of most fractures. ${ }^{17}$ Third, since we only included clinical vertebral fractures, our results are not valid for morphometric vertebral fractures. ${ }^{18,19}$ Fourth, $98.5 \%$ of all women in our study population were Caucasian, and our results need confirmation in other ethnic groups. Finally, we do not know the exact drop-out rate. However, our calculated drop-out rate per year was low, presumably because we included women from menopause onwards, so their mean age was lower than in other studies.

\section{Conclusion}

In conclusion, our results indicate that from menopause onwards, clinical vertebral and non-vertebral fractures cluster in time. During our long-term follow-up, one out of four of all subsequent fractures occurred within 1 year after a first fracture, and half occurred within 5 years, indicating the need for early action after a first fracture to prevent subsequent fractures. 


\section{References}

1. Klotzbuecher CM, Ross PD, Landsman PB, et al. Patients with prior fractures have an increased risk of future fractures: a summary of the literature and statistical synthesis. J Bone Miner Res 2000; 15(4): 721-7.

2. Geel van ACM, Geusens P, Nagtzaam IF, et al. Timing and risk factors of clinical fractures among postmenopausal women: A 5-year prospective study. BMC Med 2006; 4(24).

3. Helden van S, Cals J, Kessels F, et al. Risk of new clinical fractures within 2 years following a fracture. Osteoporos Int 2006; 17(3): 348-54.

4. Lindsay RL, Silverman SL, Cooper C, et al. Risk of new vertebral fracture in the year following a fracture. JAMA 2001; 285(3): 320-3.

5. Johnell O, Kanis JA, Oden A, et al. Fracture risk following an osteoporotic fracture. Osteoporos Int 2004; 15(3): 175-9.

6. Center JR, Bliuc D, Nguyen TV, et al. Risk of subsequent fracture after low-trauma fracture in men and women. JAMA 2007; 297(4): 387-94.

7. Geel van TACM, Geusens PP, Nagtzaam IF, et al. Risk factors for clinical fractures among postmenopausal women: a 10-year prospective study. Menopause Int 2007; 13(3): 110-5.

8. Voort van der DJM, Brandon S, Dinant GJ, et al. Screening for Osteoporosis Using Easily Obtainable Biometrical Data: Diagnostic Accuracy of Measured, Self-Reported and Recalled BMI, and Related Costs of Bone Mineral Denisty Measurements. Osteoporos Int 2000; 11: 233-9.

9. Voort van der DJM, Dinant GJ, Rinkens PELM, et al. Construction of an algorithm for quick detection of patients with low bone mineral density and its applicability in daily general practice. J Clin Epidemiol 2000; 53: 1095-103.

10. Voort van der DJM, Geusens PP, Dinant GJ. Risk factors for osteoporosis related to their outcome: fractures. Osteoporos Int 2001; 12: 630-8.

11. Voort van der DJM, Weijer van der PHM, Barentsen R. Early menopause: Increased fracture risk at older age. Osteoporos Int 2003; 14: 525-30.

12. Kanis JA, Burlet N, Cooper C, et al. European guidance for the diagnosis and management of osteoporosis in postmenopausal women. Osteoporos Int 2008; 19: 399-428.

13. Staa van TP, Dennison EM, Leufkens HG, et al. Epidemiology of fractures in England and Wales. Bone 2001; 29(6): 517-22.

14. World Health Organisation WHO. WHO Scientific Group on the assessment of osteoporosis at primary health care level 2007; Available from: http://www.who.int/chp/topics/Osteoporosis.pdf.

15. Helden van S, Wyers CE, Dagnelie PC, et al. Risk of falling in patients with a recent fracture. BMC Musculoskelet Disord 2007; 8: 55.

16. Bischoff Ferrari HA, Dawson Hughes B, Willett WC, et al. Effect of Vitamin D on falls: a metaanalysis. JAMA 2004; 291(16): 1999-2006.

17. Ismail AA, O'Neill TW, Cockerill W, et al. Validity of self-report of fractures: results from a prospective study in men and women across Europe. EPOS Study Group. European Prospective Osteoporosis Study Group. Osteoporos Int 2000; 11(3): 248-54.

18. Nevitt MC, Ettinger B, Black DM, et al. The association of radiographically detected vertebral fractures with back pain and function: a prospective study. Ann Intern Med 1998; 128(10): 793800.

19. Nevitt MC, Thompson DE, Black DM, et al. Effect of alendronate on limited-activity days and bed-disability days caused by back pain in postmenopausal women with existing vertebral fractures. Fracture Intervention Trial Research Group. Arch Intern Med 2000; 160(1): 77-85. 


\section{Chapter 5}

\section{Bone- and fall-related fracture risks in women and men with a recent clinical fracture}

Svenhjalmar van Helden, Tineke van Geel, Piet Geusens, Alfons Kessels, Arie Nieuwenhuijzen Kruseman and Peter Brink

J Bone Joint Surg Am 2008; 90: 241-248 


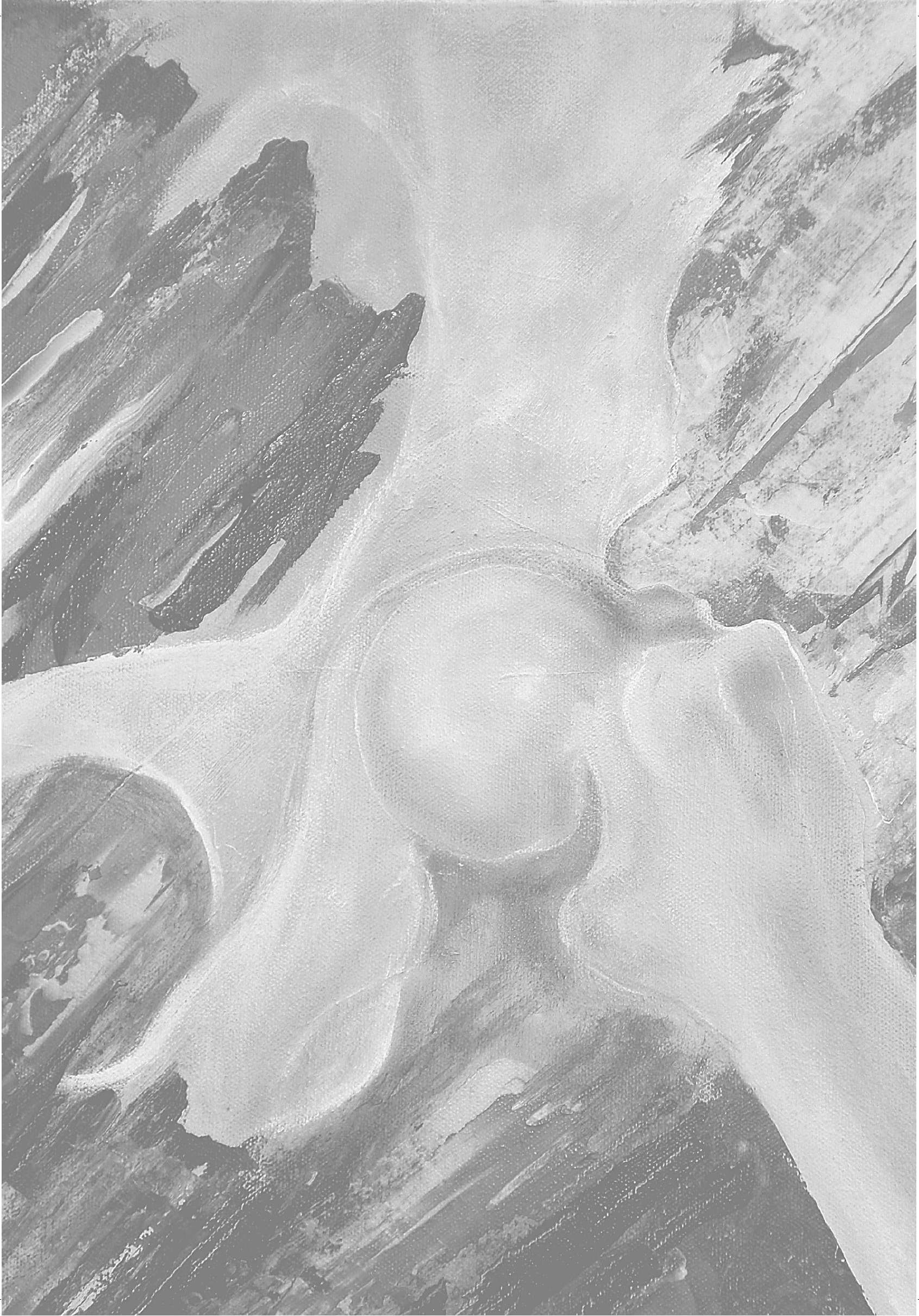




\section{Abstract}

\section{Introduction}

Worldwide fracture rates are increasing as a result of the aging population, and prevention, both primary and secondary, is an important public health goal. Therefore, we systematically analysed risk factors in subjects with a recent clinical fracture.

\section{Methods}

All men and women over fifty years of age who had been treated in the emergency department of, or hospitalised at, our institution because of a recent fracture during a one-year period were offered the opportunity to undergo an evidence-based boneand fall-related risk factor assessment and bone densitometry. The women included in this study were also compared with a group of postmenopausal women without a fracture history who had been included in another cohort study.

\section{Results}

Of the 940 consecutive patients, 797 (85\%) were eligible for this study and 568 $(60 \%)$ agreed to participate. The prevalence of fall-related risk factors $(75 \%(95 \%$ confidence interval $(\mathrm{Cl}): 71-78), n=425)$ and the prevalence of bone-related risk factors $(53 \%, \mathrm{Cl}: 49-57, \mathrm{n}=299)$ at the time of fracture were higher than the prevalence of osteoporosis $(35 \%, \mathrm{Cl}: 31-39, \mathrm{n}=201)$ as defined by a dual $\mathrm{x}$-ray absorptiometry T-score of $\leq-2.5$ in the spine and/or hip. The fall- and bone-related risk factors were present irrespective of the fracture location, patient age, or gender. An overlap between bone- and fall-related risk factors was found in $50 \%$ of the patients. After adjusting for age, weight, and height, we found that women with a fracture more frequently had a diagnosis of osteoporosis (odds ratio (OR): $2.9, \mathrm{Cl}$ : 2.0-4.1) and had a more extensive history of falls (OR: $4.0, \mathrm{Cl}: 2.7-5.9$ ) than did the postmenopausal women without a fracture history.

\section{Conclusion}

Men and women over fifty years of age who had recently sustained a clinical fracture had, at the time of that fracture, bone- and fall-related risk factors that were greater than the risk predicted by the presence of osteoporosis. Risk factors were overlapping, heterogeneous, and found in multiple combinations. This was the case regardless of the patient's age, fracture location, or gender. These findings suggest that an integrated bone- and fall-related risk-factor assessment is a preferable method for identifying elderly subjects at risk for fracture. Integrated bone and fallrelated risk assessment and treatment studies are needed to document this proposal. 


\section{Introduction}

W orldwide fracture rates are increasing as a result of the aging population, and prevention, both primary and secondary, is an important public health goal. Unfortunately, the tools currently available to prevent fractures are not well applied. A better understanding of the numerous risk factors that contribute to fractures is needed in order to improve the implementation of preventive, diagnostic, and treatment modalities for patients with a recent fracture. For both men and women, the prevalence of osteoporosis and falls increases with age, ${ }^{1}$ and between $1 \%$ and $5 \%$ of falls result in a fracture. ${ }^{2}$

In order to address this problem, numerous guidelines for evaluation of risk factors have been developed in various countries. ${ }^{3}$ Although these guidelines have been available for many years, several reports indicate that case finding and patient treatment after a fracture are poorly implemented in daily practice. ${ }^{4}$ ${ }^{5}$ Primary and secondary prevention is important for patients who are at high risk for fractures, even in the short term. ${ }^{6} 7$ Currently, most secondary prevention programs concentrate on measures that correct causes of osteoporosis. These include correcting disturbed calcium homeostasis and increasing the resistance to fractures in patients with low bone mineral density (BMD) and/or vertebral fractures. However, many patients with a clinical fracture do not have a low BMD but rather are vulnerable to fracture because of other risk factors that are applicable in the clinical context. ${ }^{8}$ Several investigators have conducted a baseline risk assessment in a population and then followed the patients to measure fracture rates. ${ }^{8-11}$ To our knowledge, no one has previously conducted a baseline assessment of both bone- and fallrelated risks in patients with a recent fracture.

Using two evidence-based guidelines produced by the National Institute of Health Care in The Netherlands, we performed, over the course of one year, a systematic screening program for risk factors in all men and women over fifty years of age who were seen with a clinical fracture at the emergency unit at our hospital. ${ }^{12,13}$ We analysed the relative presence of risk factors in these patients, determined how many patients could have been identified with use of case finding prior to their current fracture, and explored the medical consequences in reference to the risk-factor profile. 


\section{Methods}

\section{Participants}

Over the course of one year, subjects over fifty years of age who had attended the surgical emergency clinic of, or who had been admitted to, our hospital because of a clinical fracture were invited to participate in the study. Those who agreed to participate received a bone- and fall-related risk-factor assessment and bone densitometry. These investigations were done in conjunction with the fracture treatment. Patients were excluded from this study if they did not provide informed consent, did not undergo bone densitometry, were receiving treatment for osteoporosis, resided in a different region, were unavailable for the next consultation, or had a pathologic fracture as confirmed on radiographs.

\section{Measurements}

Fractures were classified, according to the International Classification of Diseases, Ninth Revision, Clinical Modification (ICD-9), into skull; spine; thorax and/or clavicle; pelvis; humerus; radius and/or ulna; hand; hip and femur; tibia, fibula, and/or patella; and foot categories. For further analyses, these categories were clustered into four groups: upper limb, lower limb, other fractures, and multiple fractures (two or more fractures at the same time).

Three assessments of fracture risk were performed:

Type A: The BMD of the spine and the left hip (or at the non-fracture site in the case of a unilateral hip fracture) were measured with dual x-ray absorptiometry (DXA) with the Hologic QDR 4500 Elite densitometer (Waltham, Massachusetts) (coefficient of variation, $0.4 \%$ ). Three patient groups were determined on the basis of the T-scores: osteoporosis (T-score $\leq-2.5$ ), osteopenia (T-score (in the hip or spine) in the range of $<-2.5$ to $\leq-1.0$ ), and normal (T-score $>-1.0)$.

Type B: Clinical bone-related risk factors for fractures, including a previous fracture after the age of fifty, a mother with a fracture history, a body weight of $<60 \mathrm{~kg}$, severe immobility, and the use of glucocorticoids, were determined.

Type C: Fall-related risk factors for fractures, including more than one fall in the past year, the use of psychoactive drugs, a low level of activities of daily living before the current fracture, articular symptoms, impaired vision, urinary incontinence, and Parkinson disease, were determined.

The assessment of risk factors for fractures was based on the Dutch guidelines for the prevention of osteoporosis and falls. ${ }^{12-14}$ These guidelines recommend case finding with the use of Type-B risk factors. Pharmaceutical treatment is 
recommended for individuals with a preexisting vertebral fracture or when other risk factors are present and the T-score is $\leq-2.5$ (Table 1). According to the fallprevention guideline, Type-C risk factors are the most important for assessment.

Table 1 Dutch osteoporosis guideline recommendations.

\begin{tabular}{|c|c|c|}
\hline & \multicolumn{2}{|c|}{ Recommendation $^{a}$} \\
\hline & Start medication & $\begin{array}{l}\text { DXA- } \\
\text { measurement }\end{array}$ \\
\hline Vertebral fracture & $\mathrm{X}$ & \\
\hline $\begin{array}{l}\text { Use of glucocorticosteroids for } \geq 3 \text { months } \\
\text { (>7.5 mg prednisone daily or equivalent) }\end{array}$ & $\mathrm{X}$ & \\
\hline Clinical fracture after age of 50 years & & $x$ \\
\hline $\begin{array}{l}\text { Women } \geq 60 \text { years of age, without a fracture history, } \\
\text { with } 3 \text { risk factors }{ }^{b}\end{array}$ & & $x$ \\
\hline $\begin{array}{l}\text { Women } \geq 70 \text { years of age, without a fracture history, } \\
\text { with } 2 \text { risk factors }{ }^{\text {b }}\end{array}$ & & $x$ \\
\hline
\end{tabular}

a Medication should be started if the T-score is $\leq-2.5$; DXA = Dual X-ray Absorptiometry

b Mother with fracture history, body weight of $<60 \mathrm{~kg}$, or severe immobility

A specialist nurse trained in osteoporosis management and fall-risk assessment evaluated all of the patients included in this study. During the first consultation, the patient was provided with information about the study and an informed consent form. If the patient agreed to participate, a DXA-measurement of the spine and hip and an investigation of bone and fall-related fracture risks were included in the second consultation. This was usually completed within two months following the fracture. The fall-risk assessment included an assessment of the ability to carry out activities of daily living with use of the Groningen Activity Restriction Scale (status before the fracture) ${ }^{15-18}$ and an assessment of the patient's vision with use of the Snellen eye chart. ${ }^{18-21}$ In addition, the examination included documentation of any history of falls, ${ }^{16,18,20,22-24}$ use of psychoactive drugs (benzodiazepines, antipsychotics, antidepressants, or neuroleptics), ${ }^{15,18,24-27}$ osteoarthritis, $^{19,20,23,25}$ urinary incontinence, $^{18,24}$ and Parkinson disease. ${ }^{19,20}$

Both the entire group and a group that had fallen from a standing height or less were analysed. A control group was included in the analysis as well. The control group was derived from a cohort of 759 postmenopausal women and comprised 492 women over the age of 50 years who had had no previous fracture. All control subjects were recruited from the practices of general practitioners. The only criterion for serving as a control subject was the absence of a fracture and 
an age above 50 years. The settings and methodology of this cohort have been described elsewhere. ${ }^{28}$

\section{Statistical analysis}

The comparison of proportions was conducted with a Chi-square test. To investigate differences between patients, univariate analyses were performed with use of binary logistic regression. Additionally, to determine the independent contributions of these risk factors, a stepwise logistic regression analysis was performed with sex, age, weight, height, and type of trauma.

The comparisons of the women in this cohort with those in the control group were also performed with use of univariate and multivariate binary logistic regression. Interaction was tested with use of multivariate analyses. Odds ratios (ORs) and 95\% confidence intervals (Cls) were calculated. Observations were considered significant when $p$ was $<0.05$ (two-tailed).

\section{Ethics}

This study was a preplanned systematic cross-sectional observational investigation and was approved by the medical ethical committee.

\section{Results}

Over the course of the year-long study period, 940 subjects over the age of 50 years presented to our emergency clinic with a fracture. Of these subjects, 229 were excluded on the basis of the previously mentioned criteria (failure to obtain a BMD study, refusal to provide informed consent, etc.) and 143 were not eligible for inclusion for various other reasons (Figure 1). As a result, 568 subjects participated in the study, giving an inclusion rate of $71 \%$ (568 of 797).

The 229 patients who chose not to participate tended to be older than those who did participate (76 compared with 67 years; $p<0.001$ ). They also more frequently had a hip fracture (27\% compared with $13 \% ; p<0.001)$; less frequently had a tibial, fibular, and/or patellar fracture $(6 \%$ compared with $15 \%$; $p=0.001)$; and less frequently had multiple fractures (1\% compared with $5 \%$; $p=0.02$ ) than the participants in this study.

The group that received a risk assessment consisted of 406 women and 162 men and had a total of 600 recent clinical fractures. A fall from a standing height or less was the cause of the fracture in 455 (80\%) of the subjects (Figure 1). Other causes included falls from more than a standing height $(6.5 \%)$, traffic 
injuries (8.5\%), entrapment of the arm or leg (3.5\%), and a small group of rare causes such as skating injuries (1.4\%). Analyses of the total group are reported because the results found for the entire group were similar to those found when separate analyses were conducted for the group that had fallen from a standing height or less.

Invited: 940

(670 women / 270 men)

143 patients not eligible for inclusion (103 women / 40 men: 23 dead, 22 dementia, 63 from another geographic region, 23 already on treatment, 12 pathological fracture

797 patients

(567 women / 230 men)

229 patients excluded (161 women / 68 men): 136 failed to obtain a bone mineral density study, 89 refused cooperation, 4 miscellaneous reasons

Used for statistical analysis: 568

(406 women / 162 men)

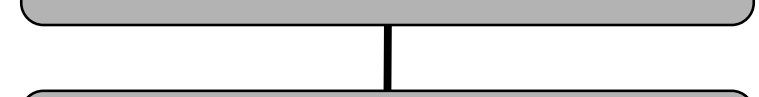

Fall from maximum standing height: 455

(354 women / 101 men)

Figure 1 Flow-chart of patient inclusion. 
The mean age was 68 years for the women compared with 65 years for the men $(p<0.001)$. An upper-limb fracture (humerus, radius and/or ulna, or hand) was sustained by $49 \%$ of the patients; a lower-limb fracture (hip and femur; tibia, fibula, and/or patella; or foot), by $37 \%$; a clinical vertebral fracture, by $3 \%$; and multiple simultaneous fractures, by $5 \%$ (Table 2 ).

Table 2 Age and distribution of fracture locations.

\begin{tabular}{lccc}
\hline & $\begin{array}{c}\text { Total group } \\
(\mathrm{n}=568)\end{array}$ & $\begin{array}{c}\text { Women } \\
(\mathrm{n}=406)\end{array}$ & $\begin{array}{c}\text { Men } \\
(\mathrm{n}=162)\end{array}$ \\
\hline Age (years) & & & 65 \\
Mean $^{\mathrm{a}}$ & 67 & 68 & 62 \\
Median $_{\text {Range }}$ & 67 & 68 & $50-90$ \\
Fracture location (No. (\%)) & $50-95$ & $50-95$ & \\
Skull & & & 0 \\
Spine & 1 & 1 & $7(4)$ \\
Thorax / clavicle & & $14(9)$ \\
Pelvis & $19(3)$ & $12(3)$ & $4(2)$ \\
Humerus & $21(4)$ & $7(2)$ & $20(12)$ \\
Radius / ulna & $7(2)$ & $20(12)$ \\
Hand & $11(2)$ & $72(18)$ & $19(12)$ \\
Hip / femur & $92(16)$ & $105(26)$ & $25(15)$ \\
Tibia / fibula / patella & $125(22)$ & $41(10)$ & $19(12)$ \\
Foot & $60(11)$ & $51(13)$ & $22(14)$ \\
Multiple & $76(13)$ & $65(16)$ & $12(7)$ \\
\hline
\end{tabular}

There was a significant difference $(p<0.05)$ between men and women

Osteoporosis of the hip and/or spine (T-score $\leq-2.5)$ was found in 201 subjects (35\%, Cl: 31-39); osteopenia, in 250 (44\%, Cl: 40-48); and normal BMD (BMD), in $117(21 \%, \mathrm{Cl}: 17 \%-24 \%)$ (Table 3).

At least one bone-related risk factor was found in 299 of the subjects $(53 \%$, $\mathrm{Cl}$ : 49-57) (Table 3). Of these 299 subjects, $14 \%$ had two risk factors, $3 \%$ had three risk factors, and one patient had four risk factors. In total, 131 subjects $(23 \%)$ had a previous fracture after the age of 50 years.

Women and men had a similar prevalence of bone-related risk factors, except for low body weight $(20 \%$ compared with $12 \%$, respectively, $p<0.05)$ and a previous fracture after the age of fifty (27\% compared with $13 \%$, respectively, $p<0.05)$, which were found more frequently in women. 
Table 3 Prevalence of risk factors in the total group and according to gender.

\begin{tabular}{|c|c|c|c|c|c|c|}
\hline & \multicolumn{2}{|c|}{$\begin{array}{l}\text { Total group } \\
(\mathrm{n}=568)\end{array}$} & \multicolumn{2}{|c|}{$\begin{array}{l}\text { Women } \\
(n=406)\end{array}$} & \multicolumn{2}{|c|}{$\begin{array}{c}\text { Men } \\
(n=162)\end{array}$} \\
\hline & $\%$ & No. & $\%$ & No. & $\%$ & No. \\
\hline \multicolumn{7}{|l|}{ BMD measured with $D X A^{a}$} \\
\hline \multicolumn{7}{|l|}{$\mathrm{T}$-score $\leq-1.0$ and $>-2.5$} \\
\hline Spine & 39 & 220 & 39 & 159 & 38 & 61 \\
\hline Hip & 46 & 255 & 48 & 192 & 40 & 63 \\
\hline Spine or hip & 44 & 250 & 44 & 179 & 44 & 71 \\
\hline \multicolumn{7}{|l|}{ T-score $\leq-2.5$} \\
\hline Spine & 30 & 172 & 32 & 131 & 25 & 41 \\
\hline Hip & 17 & 92 & $20^{c}$ & 80 & 8 & 12 \\
\hline Spine or hip & 35 & 201 & $38^{c}$ & 156 & 28 & 45 \\
\hline \multicolumn{7}{|l|}{ Bone-related risk factors } \\
\hline \multicolumn{7}{|l|}{ Fracture history ${ }^{\mathrm{b}}$} \\
\hline Clinical fracture after age of 50 years & 23 & 131 & $27^{c}$ & 110 & 13 & 21 \\
\hline Clinical vertebral fracture & 5 & 28 & 5 & 21 & 4 & 7 \\
\hline Mother with fracture history & 21 & 117 & 20 & 83 & 21 & 34 \\
\hline Body weight $<60 \mathrm{~kg}$ & 17 & 99 & $20^{c}$ & 80 & 12 & 19 \\
\hline Severe immobility & 6 & 34 & 7 & 28 & 4 & 6 \\
\hline Use of glucocorticoids & 1 & 8 & 2 & 6 & 1 & 2 \\
\hline$\geq 1$ bone-related risk factor & 53 & 299 & $56^{c}$ & 227 & 44 & 72 \\
\hline \multicolumn{7}{|l|}{ Fall-related risk factors } \\
\hline$>1$ fall last year & 28 & 158 & $31^{\mathrm{c}}$ & 124 & 21 & 34 \\
\hline Use of psychoactive drugs & 23 & 128 & $25^{c}$ & 102 & 16 & 26 \\
\hline $\begin{array}{l}\text { Low level of activities of daily living } \\
\text { (before fracture) }\end{array}$ & 26 & 140 & $29^{c}$ & 113 & 17 & 27 \\
\hline Articular symptoms & 32 & 183 & $37^{\mathrm{c}}$ & 151 & 20 & 32 \\
\hline Impaired vision & 27 & 153 & 25 & 103 & 31 & 50 \\
\hline Urine incontinence & 14 & 82 & $18^{\mathrm{c}}$ & 74 & 5 & 8 \\
\hline Parkinson disease & 0.4 & 2 & 0.5 & 2 & 0 & 0 \\
\hline$\geq$ fall-related risk factors & 75 & 425 & $78^{c}$ & 315 & 68 & 110 \\
\hline
\end{tabular}

a $\mathrm{BMD}=$ bone mineral density, $\mathrm{DXA}=$ dual X-ray absorptiometry

b Excluding the most recent fracture

c There was a significant difference $(p<0.05)$ between men and women 
At least one fall-related risk factor was found in $425(75 \%, \mathrm{Cl}: 71-78)$ of the subjects (Table 3): $33 \%$ had one risk factor, $22 \%$ had two risk factors, $10 \%$ had three risk factors, and $10 \%$ had four or more risk factors. Fall-related risk factors were more frequently seen in women, with the exception of impaired vision, which was found in $25 \%$ of the women and $31 \%$ of the men. This difference was not significant.

When all risk factors were incorporated, it became apparent that the fracture population could be divided into eight groups (Figure 2). Roughly one-quarter had only fall-related risk factors, one-fifth had both fall and bone-related risk factors, and one-fifth had fall- and bone-related risk factors as well as osteoporosis.

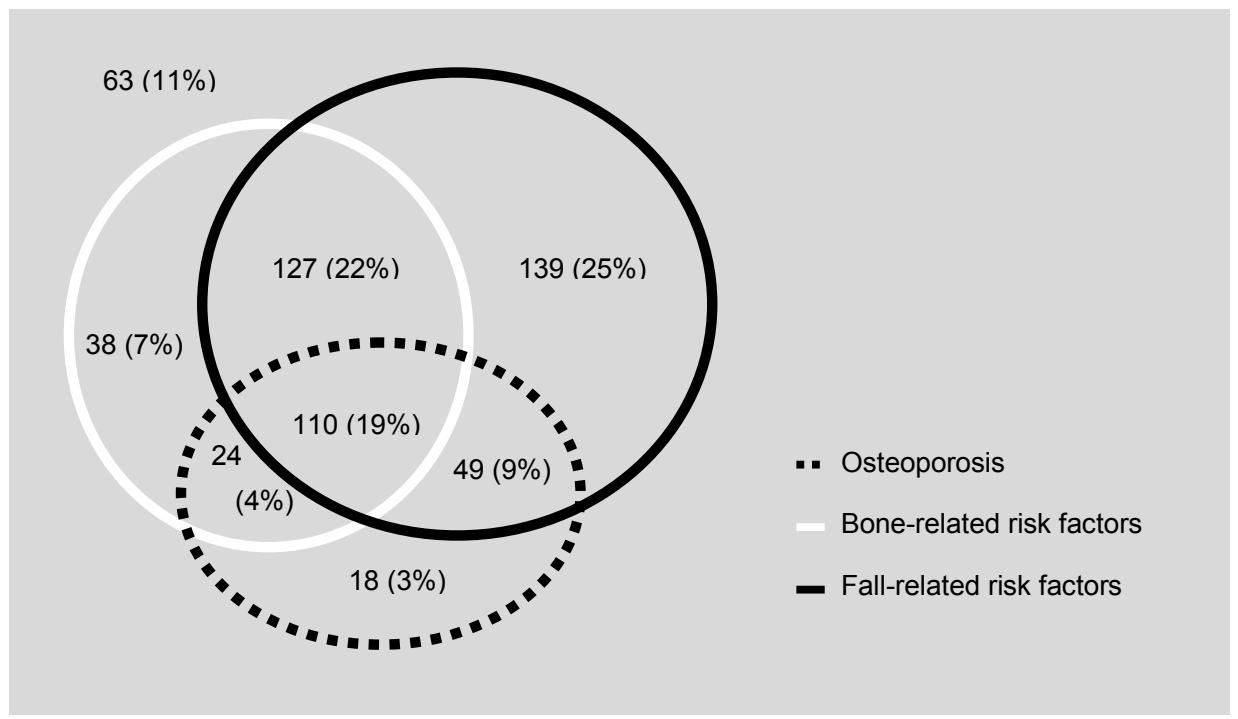

Figure 2 Distribution of bone-related risk factors, fall-related risk factors, and osteoporosis in the fracture population $(n=568)$, excluding the last fracture of each patient.

Compared with patients without any risk factors, patients with bone- and fallrelated risk fractures as well as osteoporosis were more likely to be female ( $81 \%$ compared with $56 \%, p<0.001)$, had a lower mean body weight $(77 \mathrm{~kg}$ compared with $62 \mathrm{~kg}, p<0.001)$, were shorter $(155 \mathrm{~cm}$ compared with $170 \mathrm{~cm}$, $p=0.001)$, and were more likely to have fallen from a standing height $(93 \%$ compared with $60 \%, p<0.001)$. The distribution of fracture locations was similar. 
Multivariate analyses showed that lower weight (OR: 1.1 per $\mathrm{kg}, p<0.001, \mathrm{Cl}$ : 1.05-1.15), older age (OR: 1.1 per year, $p<0.001, \mathrm{Cl}: 1.06-1.16)$, and type of trauma (in favour of a fall from standing height) (OR: 3.6, $p=0.03, \mathrm{Cl}: 1.1-11.6$ ) were significantly associated with the presence of all three types of fracture risk.

Regardless of the fracture location, fall-related risk factors were more frequent than bone-related risk factors, which in turn were more frequent than osteoporosis (Figure 3). The prevalence of osteoporosis was highest in patients with clinical vertebral fractures $(63 \%)$ and in those with multiple fractures $(45 \%)$.

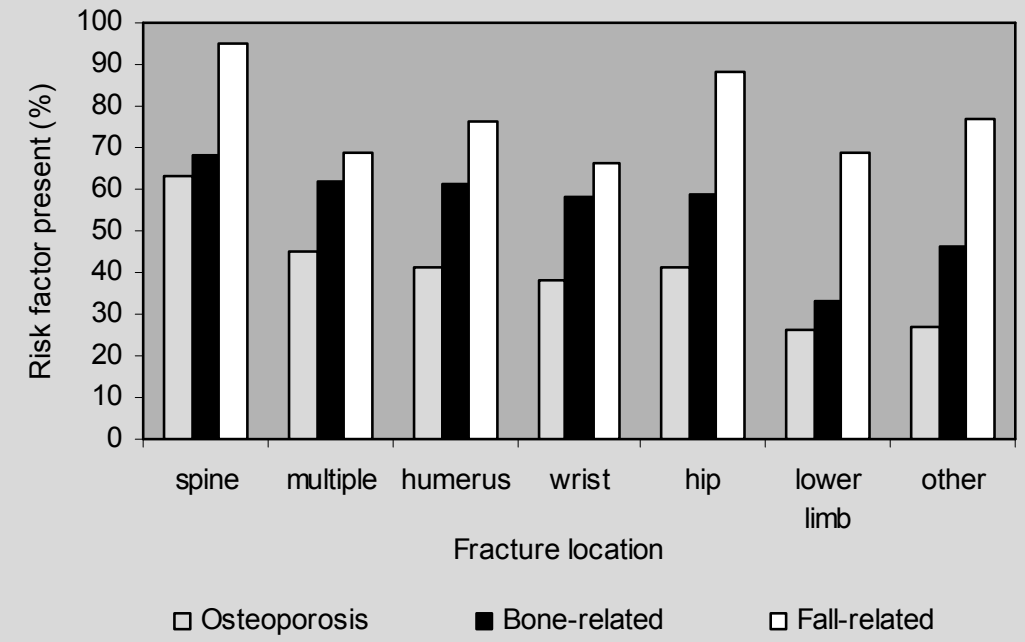

Figure 2 Risk factors according to the fracture location $(n=568)$.

Compared with patients with osteoporosis, patients with osteopenia (T-score (in the hip or spine) in the range of $<-2.5$ to $\leq-1.0$ ) were younger (67 compared with 70 years, $p<0.01$ ) and had a lower prevalence of clinical bone-related risk factors $(48 \%$ compared with $67 \%, p<0.01)$. The distribution of fracture locations was the same in patients with osteopenia and those with osteoporosis, with the exception of vertebral fractures, which were slightly more frequent in the osteoporosis group ( $6 \%$ compared with $2 \%, p=0.05)$.

The 406 women in this cohort and a cohort of 492 women with no fracture history were compared with regard to age, height, weight, prevalence of osteoporosis of the spine and/or hip, maternal fracture history, steroid use, Parkinson disease, use of sedatives, and the occurrence of two or more falls in the previous twelve months. When compared with the control group, the 
patients with a recent fracture tended to be slightly older (68 compared with 65 years, $p<0.0001$ ), weigh less (69 kg compared with $71 \mathrm{~kg}, p=0.03$ ), have a higher prevalence of osteoporosis in the spine and/or hip (38\% compared with $19 \%, p<0.0001)$, and have a higher prevalence of two or more falls in the previous twelve months (31\% compared with $11 \%, p<0.0001)$. Multivariate logistic regression analyses showed that, when adjusted for age, weight, and height, the above-mentioned differences were independent of the presence of osteoporosis (OR: 2.9, Cl: 2.0-4.1) and the history of falls (OR: 4.0, $\mathrm{Cl}: 2.7-5.9$ ). Interaction was only significant for age and the presence of osteoporosis $(p=0.02)$.

Using the Dutch osteoporosis guideline, ${ }^{12}$ we determined that $83 \%$ of the women with a clinical fracture would not have been identified as being at risk for a fracture before they had the recent fracture.

\section{Discussion}

In a cohort of patients over 50 years of age who had been admitted to the emergency clinic of our hospital because of a recent clinical fracture, a heterogeneous mixture of bone and fall-related risks for fractures was found in both sexes, in association with all fracture locations, and irrespective of the patient's age, even when the analyses were limited to patients who had sustained the fracture in a simple fall. Osteoporosis (a BMD T-score of $\leq-2.5$ ) was present in one third of the patients, while half of the patients had at least one bone-related risk factor and three-quarters of the patients had at least one fall-related risk factor before the current fracture. The majority $(71 \%)$ of this study population were women, and therefore the conclusions are predominantly based on results found in women.

These results highlight two important issues. First, most guidelines focus on identifying osteoporosis, as opposed to risk factors for fractures, and therefore they fail to prospectively identify most individuals at risk for fractures. Only a limited number of the patients in our study could have been identified, before their current clinical fracture, with use of the Dutch guideline. This indicates the need for additional approaches to identifying patients at risk for clinical, and usually nonvertebral, fractures. Such an initiative is under way with the World Health Organisation (WHO) initiative to calculate the absolute fracture risk on the basis of BMD and a group of clinical bone-related risk factors that is larger than that included in the Dutch guideline; the WHO list of bone-related risk factors includes use of multiple medications, cigarette smoking, excessive 
alcohol intake, rheumatoid arthritis, and self-rated poor health status. ${ }^{29}$ WHO acknowledges that it chose to include only bone-related risks in this initiative. It identified the importance of fall-related risks but excluded them. In view of our results, the algorithms proposed by WHO could therefore underestimate fracture risk in patients with a higher risk of falls. To what extent such algorithms could overestimate the fracture risk in patients who have a lower risk of falls is also unclear and needs to be addressed in large-scale prospective population studies integrating both bone-related and fall-related risks. Indeed, Nguyen et al. reported that both bone- and fall-related risk factors were predictive of hip fractures, the most important clinical fractures, over a period of 14 years. ${ }^{30} \mathrm{~A}$ recent review on osteoporosis by Sambrook and Cooper supported the view that case finding and therapeutic strategies will shift from an approach based primarily on BMD measurements to an approach in which both fall- and bonerelated fracture risk factors are used to predict the absolute fracture risk. ${ }^{31}$ Our data support this view and indicate that this approach may be particularly valuable in the context of patients entering the hospital for the treatment of $a$ fracture.

The second important finding of our study is that most patients with a recent clinical fracture do not have osteoporosis. Thus, simply ordering a DXA scan to select patients for treatment means that many patients with a high fracture risk will be discharged without further treatment. In these cases, the bone-related risk factors independent of BMD and the fall-related risk factors will persist and will therefore need to be addressed and corrected whenever possible. Indeed, in our study, $53 \%$ of the patients had bone-related risk factors other than low BMD, for which there are potentially several structural and material bone-related reasons, including structural features (micro-architecture and macroarchitecture), high bone turnover, and material characteristics such as hypomineralisation in the context of high bone turnover and osteomalacia, genetic polymorphisms (e.g., of collagen type I), and changes in collagen crosslinking. ${ }^{32-34}$ As most patients in our study had had a fall, the high prevalence of fall-related risk factors was not unexpected. However, the frequent combination of fall and bone-related risk factors indicates that, in the context of case finding, those who fall need to be evaluated for bone-related risk factors and low BMD (two of three patients who had fallen also had bone-related risk factors and/or low BMD) and patients with bone-related risk factors and/or low BMD need to be evaluated for fall-related risk factors (four of five also had fall-related risk factors). However, the clinical relevance of fall-related-risk evaluation and prevention for these patients remains unclear. Various studies have demonstrated a beneficial effect of focused or multifactorial fall prevention 
programs on the incidence of falls, but none have shown that this leads to fracture reduction. $2,35,36$

This study had several shortcomings. The number of patients included could be interpreted as small when compared with the numbers in prospective studies in which bone- and fall-related risks were evaluated in several thousand subjects. 3738 However, our study is by far the largest evaluating both bone- and fallrelated risk factors in patients with a recent clinical fracture. McLellan et al. conducted a study of 4600 patients with a recent fracture, but they only evaluated BMD. ${ }^{39}$ Becker et al. described 185 men and women with a recent fracture, but they focused mainly on causes of secondary osteoporosis and the influence of ethnicity. ${ }^{40}$ They found a mean of 3.2 fall-related risk factors and a history of fracture in $40 \%$ of their patients. However, their study was based on a retrospective chart review. A second shortcoming of our study is that blood sampling was not performed, as it was in the study by Streeten et al. ${ }^{41}$ Blood sampling may be important for diagnosing secondary causes of low BMD. Third, some bone-related risk factors (excessive alcohol intake, smoking, rheumatoid arthritis, and self-rated poor health status) were not included in our study because they are not included in the Dutch osteoporosis guideline. Miller et al. reported that an algorithm that included self-reported poor health for assessment of women with osteopenia correctly classified $74 \%$ of those who had sustained a fracture. ${ }^{8}$ As self-reported poor health was not part of our evaluation, it remains to be determined if this additional information could have increased the proportion of patients who could have been identified as being at risk. Fourth, $15 \%$ of the patients were not eligible for assessment and, of those who were eligible, $29 \%$ did not provide informed consent or failed to return for the BMD study. Therefore, the conclusions drawn from these data are applicable only to those patients who are willing to cooperate with an assessment for fracture risk. The results show that older patients and patients with a hip fracture were less willing to participate in such a program. Fifth, riskfactor assessment was conducted during the fracture treatment period in a study with a cross-sectional design. This may have affected recall regarding these risk factors. However, the evaluation was performed within two months after the fracture for most patients. As a result, recall bias was probably quite low. Sixth, a control group was available only for the female subjects in this cohort. Lastly, we must consider that not all clinical vertebral fractures are treated at the emergency department and that two of every three fractures do not have the clinical picture of an acute fracture. Therefore, no data on nonclinical morphometric vertebral fractures were obtained. 


\section{Conclusion}

In summary, fracture prevention is essential to improve the quality of life of our growing elderly population. In order to be successful, we need to move beyond using bone-related or fall-related risk factors as the only, or as separate, risk factors for clinical fractures and we must develop screening tools that combine bone- and fall-related risk factors in prospective population studies to better identify a greater proportion of the at-risk population. 


\section{References}

1. Francis RM. Falls and fractures. Age Ageing 2001; 30 Suppl 4: 25-8.

2. Tinetti ME. Preventing falls in elderly persons. N Engl J Med 2003; 348(1): $42-9$.

3. Geusens P, Milisen K, Dejaeger E, et al. Falls and fractures in postmenopausal women: A review. J Br Menopause Soc 2003; 9(3): 101-6.

4. Dreinhofer KE, Anderson M, Feron JM, et al. Multinational survey of osteoporotic fracture management. Osteoporos Int 2005; 16 Suppl 2: S44-53.

5. Hegeman JH, Willemsen $\mathrm{G}$, van Nieuwpoort $\mathrm{J}$, et al. Effective tracing of osteoporosis at a fracture and osteoporosis clinic in groningen; an analysis of the first 100 patients. Ned Tijdschr Geneeskd 2004; 148(44): 2180-5.

6. Johnell $\mathrm{O}$, Kanis $\mathrm{JA}$, Odén $\mathrm{A}$, et al.: Fracture risk following an osteoporotic fracture. Osteoporos Int 2004; 15(3): 175-9.

7. Helden van $\mathrm{S}$, Cals $\mathrm{J}$, Kessels $\mathrm{F}$, et al. Risk of new clinical fractures within 2 years following a fracture. Osteoporos Int 2006; 17(3): 348-54.

8. Siris ES, Chen YT, Abbott TA, et al. Bone mineral density thresholds for pharmacological intervention to prevent fractures. Arch Intern Med 2004; 164(10): 1108-12.

9. Cummings SR, Nevitt MC, Browner WS, et al. Risk factors for hip fracture in white women. Study of osteoporotic fractures research group. N Engl J Med 1995; 332(12): 767-73.

10. Nevitt MC, Cummings SR, Stone KL, et al. Risk factors for a first-incident radiographic vertebral fracture in women $>$ or $=65$ years of age: The study of osteoporotic fractures. $\mathrm{J}$ Bone Miner Res 2005; 20(1): 131-40.

11. Siris ES, Chen YT, Abbott TA, et al. Bone mineral density thresholds for pharmacological intervention to prevent fractures. Arch Intern Med 2004; 164(10): 1108-12.

12. Kwaliteitsinstituut voor de Gezondheidszorg CBO. Osteoporose tweede herziene richtlijn. 2002, Alphen aan de Rijn: Van Zuiden Communications BV.

13. Kwaliteitsinstituut voor de Gezondheidszorg СBO. Preventie van valincidenten bij ouderen. 2004; Available from: www.cbo.nl/product/richtlijnen/folder20021023121843/valrichtlijn2004.Pdf.

14. Geusens PP, Lems WF, Verhaar HJ, et al. Review and evaluation of the dutch guidelines for osteoporosis. J Eval Clin Pract 2006; 12(5): 539-48.

15. Tinetti ME, Speechley M,Ginter SF. Risk factors for falls among elderly persons living in the community. N Engl J Med 1988; 319(26): 1701-7.

16. Jaglal SB, Mclsaac WJ, Hawker G, et al. Information needs in the management of osteoporosis in family practice: An illustration of the failure of the current guideline implementation process. Osteoporos Int 2003; 14(8): 672-6.

17. O'Loughlin JL, Robitaille $\mathrm{Y}$, Boivin JF, et al. Incidence of and risk factors for falls and injurious falls among the community-dwelling elderly. Am J Epidemiol 1993; 137(3): 342-54.

18. Tromp AM, Pluijm SM, Smit JH, et al. Fall-risk screening test: A prospective study on predictors for falls in community-dwelling elderly. J Clin Epidemiol 2001; 54(8): 837-44.

19. Nevitt MC, Cummings SR, Kidd S, et al. Risk factors for recurrent nonsyncopal falls. A prospective study. JAMA 1989; 261(18): 2663-8.

20. Northridge ME, Nevitt MC,Kelsey JL. Non-syncopal falls in the elderly in relation to home environments. Osteoporos Int 1996; 6(3): 249-55.

21. Lord SR, Dayhew J. Visual risk factors for falls in older people. J Am Geriatr Soc 2001; 49(5): 508-15. 
22. Luukinen H, Koski K, Kivela SL, et al. Social status, life changes, housing conditions, health, functional abilities and life-style as risk factors for recurrent falls among the home-dwelling elderly. Public Health 1996; 110(2): 115-8.

23. Stalenhoef PA, Diederiks JP, Knottnerus JA, et al. A risk model for the prediction of recurrent falls in community-dwelling elderly: A prospective cohort study. J Clin Epidemiol 2002; 55(11): 1088-94.

24. Luukinen $\mathrm{H}$, Koski K, Laippala $\mathrm{P}$, et al. Predictors for recurrent falls among the home-dwelling elderly. Scand J Prim Health Care 1995; 13(4): 294-9.

25. Campbell AJ, Borrie MJ, Spears GF. Risk factors for falls in a community-based prospective study of people 70 years and older. J Gerontol 1989; 44(4): M112-7.

26. Schwartz AV, Villa ML, Prill M, et al. Falls in older Mexican-American women. J Am Geriatr Soc 1999; 47(11): 1371-8.

27. Weiner DK, Hanlon JT,Studenski SA. Effects of central nervous system polypharmacy on falls liability in community-dwelling elderly. Gerontology 1998; 44(4): 217-21.

28. Geel van ACM, Geusens P, Nagtzaam IF, et al. Timing and risk factors of clinical fractures among postmenopausal women: A 5-year prospective study. BMC Med 2006; 4(24).

29. Kanis JA, Borgstrom F, De Laet C, et al. Assessment of fracture risk. Osteoporos Int 2005; 16(6): 581-9.

30. Nguyen ND, Pongchaiyakul C, Center JR, et al. Identification of high-risk individuals for hip fracture: A 14-year prospective study. J Bone Miner Res 2005; 20(11): 1921-8.

31. Sambrook P, Cooper C. Osteoporosis. Lancet 2006; 367(9527): 2010-8.

32. Bouxsein ML, Karasik D. Bone geometry and skeletal fragility. Curr Osteoporos Rep 2006; 4(2): 49-56.

33. Garnero P. Markers of bone turnover for the prediction of fracture risk. Osteoporos Int 2000; 11 Suppl 6: S55-65.

34. Uitterlinden $\mathrm{AG}$, Weel $\mathrm{AE}$, Burger $\mathrm{H}$, et al. Interaction between the vitamin d receptor gene and collagen type ialpha1 gene in susceptibility for fracture. J Bone Miner Res 2001; 16(2): 379-85.

35. Close $\mathrm{J}$, Ellis $\mathrm{M}$, Hooper R, et al. Prevention of falls in the elderly trial (profet): A randomised controlled trial. Lancet 1999; 353(9147): 93-7.

36. Chang JT, Morton SC, Rubenstein LZ, et al. Interventions for the prevention of falls in older adults: Systematic review and meta-analysis of randomised clinical trials. BMJ 2004; 328(7441): 680 .

37. Nguyen TV, Center JR, Sambrook PN, et al. Risk factors for proximal humerus, forearm, and wrist fractures in elderly men and women: The Dubbo osteoporosis epidemiology study. Am J Epidemiol 2001; 153(6): 587-95.

38. Sambrook PN, Cameron ID, Chen JS, et al. Influence of fall related factors and bone strength on fracture risk in the frail elderly. Osteoporos Int 2007; 18(5): 603-10.

39. McLellan AR, Gallacher SJ, Fraser M, et al. The fracture liaison service: Success of a program for the evaluation and management of patients with osteoporotic fracture. Osteoporos Int 2003; 14(12): 1028-34.

40. Becker $\mathrm{C}$, Crow S, Toman J, et al. Characteristics of elderly patients admitted to an urban tertiary care hospital with osteoporotic fractures: Correlations with risk factors, fracture type, gender and ethnicity. Osteoporos Int 2006; 17(3): 410-6.

41. Streeten EA, Mohamed A, Gandhi A, et al. The inpatient consultation approach to osteoporosis treatment in patients with a fracture. Is automatic consultation needed? J Bone Joint Surg Am 2006; 88(9): 1968-74. 


\title{
Chapter 6
}

\begin{abstract}
Measures of bioavailable serum testosterone and estradiol and their relationships with muscle mass, muscle strength and bone mineral density in postmenopausal women: a cross-sectional study
\end{abstract}

Tineke van Geel, Piet Geusens, Bjorn Winkens, Jean-Pierre Sels and Geert-Jan Dinant

Submitted for publication 


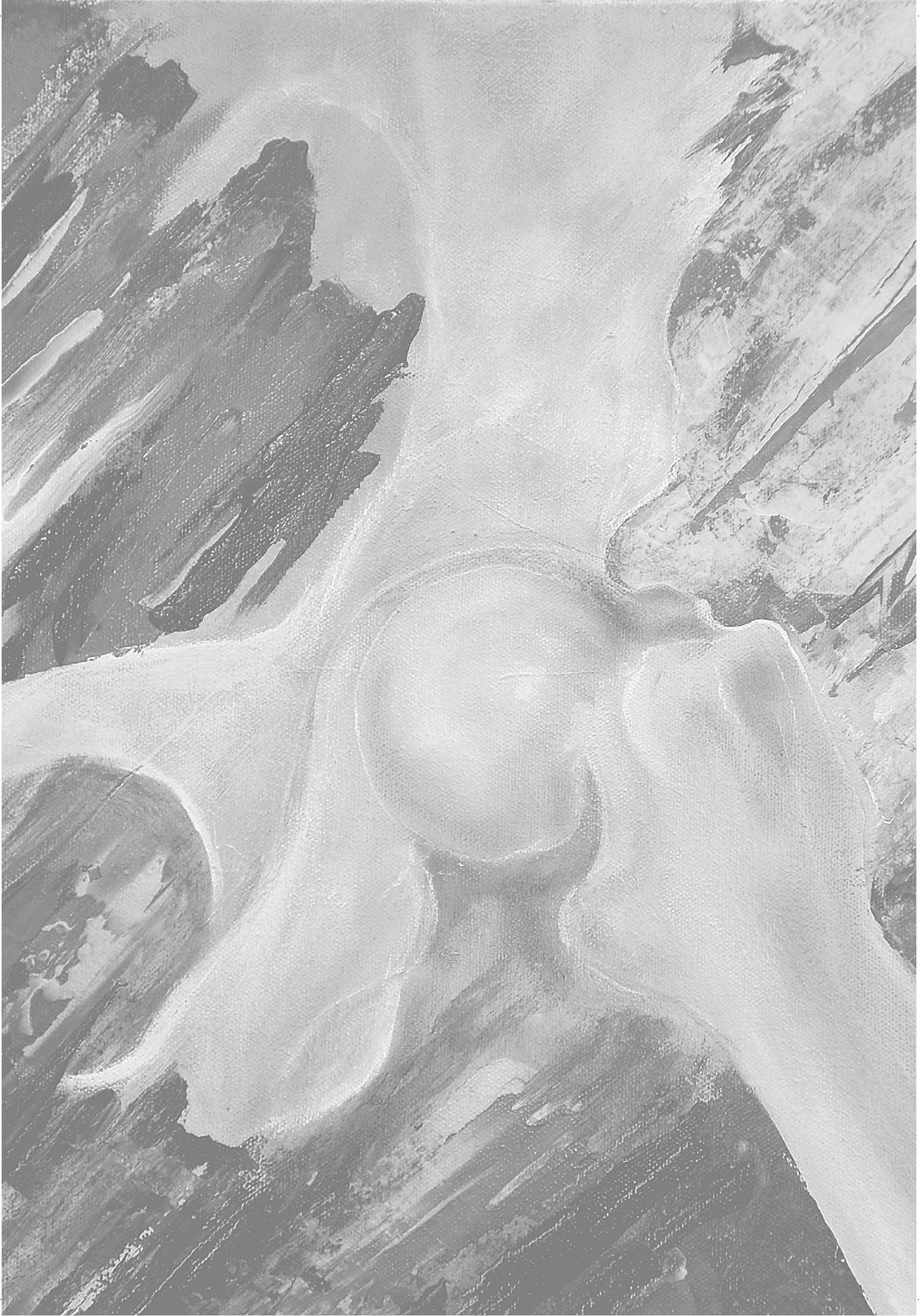




\section{Abstract}

\section{Introduction}

The physiologic role of circulating endogenous testosterone $(T)$ and estrogen (E) concentrations in relation to lean body mass (LBM) and muscle strength is not as well documented in postmenopausal women as in elderly men.

\section{Methods}

329 healthy postmenopausal women were randomly selected from a GP population-based sample aged between 55 and 85 years.

Total $\mathrm{T}(\mathrm{TT})$ and $\mathrm{E}(\mathrm{TE})$, and sex hormone-binding globulin (SHBG) were determined and estimates of bioavailable $T$ (free androgen index (TT/SHBG, FAl), free T/TT (FTR), bioavailable T/TT (BTR)) and E (TE/SHBG, ESR) were calculated.

Examinations included bone mineral density (BMD) of the spine and femoral neck (FN), LBM, maximum quadriceps extension strength (MES) and handgrip strength (MGS), timed up-and-go test (TUGT), osteocalcin (OC) and urinary deoxypyridinoline/creatinine (DPyr) levels. The relation between these variables was assessed using Pearson's correlation coefficient $(r)$.

\section{Results}

With advancing age, LBM, MES, MGS, BMD, FTR, BTR and ESR significantly declined (range $r:-0.356$ to $-0.141, p<0.05)$ and TUGT $(r: 0.282)$, and DPyr $(r$ : 0.135) significantly increased $(p<0.05)$. After age-adjustment, LBM, MES and $\mathrm{BMD}$ in spine and $\mathrm{FN}$ were significantly related to bioavailable $\mathrm{T}$ (range $r$ : 0.138 to 0.332 , for FTR, and 0.157 to 0.229 , for FAI) and to ESR (range $r: 0.162$ to 0.274$)$. OC and DPyr were significantly inversely related to ESR ( $r:-0.155$ and -0.144 , respectively).

\section{Conclusion}

Age-related loss of LBM, MES (but not MGS) and BMD in postmenopausal women is partly dependent on the presence of endogenous bioavailable $T$ and E. 


\title{
List of abbreviations
}

\author{
BMD Bone mineral density \\ cFT Calculated free testosterone \\ cBaT Calculated bioavailable testosterone \\ DPC Diagnostic products cooperation \\ DXA Dual-energy X-ray absorptiometry \\ E Estrogen \\ $\mathrm{E}_{2} \quad$ Estradiol \\ FN Femoral neck \\ $\mathrm{fE} \quad$ Free endrogen \\ fT Free testosterone \\ LBM Lean body mass \\ KTA Binding of testosterone to albumin: $4.06{ }^{*} \mathrm{t} 4$, per (Sodergard et al.); ${ }^{1}$ \\ $4.00 * \mathrm{t} 4$, per (Dunn et al); ${ }^{2} 3.60{ }^{*} \mathrm{t} 4$, per (Vermeulen et al.) ${ }^{3} \mathrm{t} 4=10^{4}$ \\ KTS Binding of testosterone to SHBG: 16.0 * t8, per (Dunn et al); ${ }^{2} 10.0^{*}$ t8, \\ per (Vermeulen et al. $){ }^{3} 5.97{ }^{*}$ t8, per (Sodergard et al. $) ;{ }^{1}$ t8 $=10^{8}$ \\ MES Maximum quadriceps extension strength \\ MGS Maximum handgrip strength \\ OC Osteocalcin \\ $\mathrm{p} \quad$ Level of significance \\ $r \quad$ Correlation coefficient \\ SD Standard deviation \\ SHBG Sex hormone-binding globulin \\ $\mathrm{T} \quad$ Testosterone \\ TE Total estrogen \\ TT Total testosterone \\ TUGT Timed up-and-go test
}

Ratios

BTR Calculated bioavailable testosterone ratio (bioavailable T/TT)

DPyr deoxypyridinoline/creatinine ratio

ESR TE/SHBG

FAI Free androgen index (TT/SHBG)

FTR Calculated free testosterone ratio (free T/TT) 


\section{Introduction}

T $t$ is well documented that part of the bone loss that occurs with aging in postmenopausal women and elderly men is related to a decrease in serum levels of bioavailable estrogen $(E)$ and testosterone $(T),{ }^{4-8}$ and that drugs with estrogenic and/or androgenic properties can be used to prevent age-related bone loss. ${ }^{4,}$, 10

It has been shown that part of the loss of lean (fat-free) body mass, muscle mass and maximum voluntary strength that occurs with aging in elderly men is related to bioavailable $T,{ }^{4,11}$ and most, though not all, studies have found that $T$ administration to hypogonadal and eugonadal men is associated with dose- and concentration-dependent increase in lean mass, muscle mass and maximum voluntary strength. ${ }^{10-13}$ In men, testosterone increases muscle protein synthesis and satellite cell number, probably by stimulating the differentiation of mesenchymal pluripotent cells to the myogenic lineage, ${ }^{13}$ resulting in muscle fiber hypertrophy and myonuclear number increase. ${ }^{13,14}$

In postmenopausal women, not enough is known about the relation between serum $E$ and the decrease in muscle mass and muscle strength, and the physiological significance of low $T$ in relation to muscle mass and muscle strength remains unclear. ${ }^{15,16}$ Data on the effects of $E$ and $T$ administration on muscle mass and muscle strength in postmenopausal women are scarce, much more so than those for elderly men. ${ }^{17,18}$

Serum $T$ and $E$ are mainly bound to sex-hormone binding globulin (SHBG) and albumin. Albumin-bound and free $T(f T)$ and $E(f E)$ are believed to have access to target tissues. ${ }^{4,19}$ Several methods to calculate $\mathrm{fT}$ from adequately measured $T$ and SHBG by immunoassay are available and some have been shown to be a reliable index of bioavailable $\mathrm{T}^{3}$ The same holds for $\mathrm{E}{ }^{4}$

The present cross-sectional study of 329 postmenopausal women therefore tested the hypothesis that the decreases in muscle mass, muscle strength and bone density with age are related to the drop in circulating endogenous $T$ and $E$ concentrations. 


\section{Methods}

\section{Participants}

Twenty general practitioners (GPs) from 10 general practice centres participated in the original population-based cohort study. The region consists of two towns in the southern part of the Netherlands, surrounded by suburban villages. ${ }^{20}$ We drew a random sample of 370 postmenopausal women aged between 55 and 85 years from the 4203 women who were included in the original study. All participating women signed an informed consent form.

\section{Measurements}

\section{Muscle mass and muscle strength}

The assessments conducted in 1998-99 started with weight (in kilograms), height (in centimetres) and total body lean mass (LBM), measured by dualenergy X-ray absorptiometry (DXA) (Hologic QDR-1000, Hologic Europe, Brussels, Belgium).

Quadriceps extension strength was measured using the Chatillon DFIS-200 (Largo, Florida, USA), and handgrip strength using the Jamar dynamometer (Sammons Preston, Jackson, MI, USA). Quadriceps muscle strength was measured thrice in both legs and the handgrip strength thrice in both hands. Maximum quadriceps extension (MES) and handgrip strength (MGS) were defined as the maximum strength of the left or right leg / hand, whichever was largest.

Mobility was tested using the timed up-and-go test (TUGT), ${ }^{21}$ which measures the time needed to get up from a chair, walk three metres, turn, walk back, and sit down again.

\section{Hormone measurements}

Blood samples were collected in the morning after an overnight fast, and first morning urine samples were collected as well. All laboratory tests, except for urinary creatinine (which was performed measured with the methods used in routine practice), were obtained with the IMMULITE device (Diagnostic Products Corporation (DPC), Los Angeles, CA). 
Radioimmunoassay (RIA) was used to measure sex-hormone binding globulin (SHBG, intra-coefficient of variation (CV) of $2.4-4.4 \%$ and inter-CV of $3.7-7.0 \%$ ), testosterone (T, intra-CV of $7.1-13.0 \%$ and inter-CV of $7.7-16.4 \%$ ) and estradiol $\left(E_{2}\right.$, intra-CV of $4.3-9.9 \%$ and inter-CV of $\left.6.7-16.0 \%\right)$.

Based on these values, parameters of bioavailable $T$ and $E$ were calculated according to the methods proposed in the endocrine literature (Table 1). These included the free androgen index (FAI), calculated free testosterone (cFT) and bioavailable testosterone (cBaT, i.e. circulating testosterone not bound to SHBG), cFT / total testosterone (TT) ratio (FTR), and cBaT / TT ratio (BTR). $\mathrm{cFT}, \mathrm{BaT}, \mathrm{FTR}$, and BTR were calculated using three values of 'binding of testosterone to SHBG' constant (KTS). ${ }^{1-3}$ The KTS, FT, and BaT were used to calculate the $\mathrm{FT} /$ total testosterone ratio (FTR) and $\mathrm{BaT} /$ total testosterone ratio (BTR) (Table 1).

Table 1 Measurements and calculations for the various concentrations of $\mathrm{T}$ and $\mathrm{E} .{ }^{\mathrm{a}}$

\begin{tabular}{|c|c|}
\hline & Measurements and calculations \\
\hline SHBG (nmol/L) & RIA (DPC, IMMULITE2000, Los Angeles, CA) \\
\hline $\mathrm{TT}(\mathrm{nmol} / \mathrm{L})$ & RIA (DPC, IMMULITE2000, Los Angeles, CA) \\
\hline $\mathrm{FAI}(\% \mathrm{M} / \mathrm{M})$ & $\mathrm{FAI}=100 *$ TTE $/ \mathrm{SHBG}$, with both in $\mathrm{nmol} / \mathrm{L}$ \\
\hline \multirow[t]{4}{*}{$\mathrm{cFT}(\mathrm{pmol} / \mathrm{L})$} & According to Dunn et al. ${ }^{2}$, Sodergard et al. ${ }^{1}$ and Vermeulen et al.: \\
\hline & $\mathrm{CFT}=[-\mathrm{b}+\sqrt{ }(\mathrm{b} 2+4 \mathrm{a}[\mathrm{TT}]] / 2 \mathrm{a}$ \\
\hline & $a=\mathrm{KTA}+\mathrm{KTS}+(\mathrm{KTA} \times \mathrm{KTS})([\mathrm{SHBG}]+[$ albumin $]-[\mathrm{TT}])$ \\
\hline & $\mathrm{b}=1+\mathrm{KTS}[\mathrm{SHBG}]+\mathrm{KTA}[$ albumin $]-(\mathrm{KTA}+\mathrm{KTS})[\mathrm{TT}]$ \\
\hline \multirow[t]{2}{*}{$\mathrm{cBaT}(\mathrm{nmol} / \mathrm{L})$} & According to Dunn et al. ${ }^{2}$, Sodergard et al. ${ }^{1}$ and Vermeulen et al.: \\
\hline & $\mathrm{BaT}=(\{\mathrm{KTA} \times[$ albumin $] \times[\mathrm{cFT}] /(1+\mathrm{KTA} \times[\mathrm{cFT}]\})+[\mathrm{cFT}]$ \\
\hline FTR $(\% \mathrm{M} / \mathrm{M})$ & $\mathrm{FTR}=[\mathrm{cFT}] /[\mathrm{TT}]$, with $\mathrm{cFT}$ in $\mathrm{pmol} / \mathrm{L}, \mathrm{TT}$ in $\mathrm{nmol} / \mathrm{L}$ \\
\hline BTR (\% M/M) & $\mathrm{BTR}=[\mathrm{cBaT}] /[\mathrm{TT}]$, with $\mathrm{cBaT}$ in $\mathrm{nmol} / \mathrm{L}, \mathrm{TT}$ in $\mathrm{nmol} / \mathrm{L}$ \\
\hline Estradiol (pmol/L) & RIA (DPC, IMMULITE2000, Los Angeles, CA) \\
\hline ESR $(p M / n M)$ & $\mathrm{ESR}=[\mathrm{E} 2] /[\mathrm{SHBG}]$, with $\mathrm{E} 2$ in $\mathrm{pmol} / \mathrm{L}, \mathrm{SHBG}$ in $\mathrm{nmol} / \mathrm{L}$ \\
\hline Osteocalcine (mgram/L) & RIA (DPC, IMMULITE2000, Los Angeles, CA) \\
\hline Dpyr (nM/mM) & Ppyr $=[P Y R] /[C R E]$, with PYR in $\mathrm{nmol} / \mathrm{L}, \mathrm{CRE}$ in $\mathrm{mmol} / \mathrm{L}$ \\
\hline
\end{tabular}

a List of abbreviations

Bone turnover markers (BTM) including osteocalcin (OC, intra-CV of 2.2-4.0\% and inter-CV of 5.1-9.9\%) and deoxypyridinoline/creatinine ratio (DPyr, intra-CV of $3.1-10.0 \%$ and inter-CV of $4.3-12.0 \%$ ) were measured using RIA.

\section{Bone mineral density}

Bone mineral density (BMD) was measured at the lumbar spine and at the femoral neck (FN) by the same DXA instrument as used for LBM. 


\section{Statistical analysis}

The relations between muscle strength, biochemical markers, and BMD with age were assessed using Pearson's correlation coefficient $(r)$. The $r$ shows the number of standard deviations (SD) that the outcome will change as a results on one SD change in age. ${ }^{22}$ For the variables which significantly correlated with age, the differences in mean outcome between the highest and lowest agegroups were calculated. Partial correlation coefficients (partial $r$ ) were analysed to assess the age-adjusted relation between lean body mass, muscle strength parameters, and biochemical markers. The age- and body mass index (BMI)-adjusted relation between these variables was also calculated. Observations were considered significant when $p$ was $<0.05$ (two-tailed).

SPSS software (version 15.0; SPSS Inc., Chicago, IL, USA) was used for the statistical analysis.

\section{Ethics}

The Ethics Review Committee of the Maastricht University and the Maastricht University Hospital approved the study (reference number MEC 94-196.1).

\section{Results}

Of the 352 women who agreed to participate (response rate $=95.1 \%$ ), nine women were excluded from further analyses due to severe mobility problems (e.g. wheelchair dependent, leg prosthesis, Parkinson's disease, amyotrophic lateral sclerosis). Biochemical markers were available for 329 of the remaining 343 women $(95.9 \%)$.

\section{Changes in T, E, muscle mass, muscle strength and BTM with age}

Table 2 presents the descriptive data, while Table 3 presents the relation between hormones and muscle parameters. Lean body mass (LBM), MES, and MGS declined with ageing, while TUGT significantly increased with increasing age. Women in the lowest age-group (<60 years, $n=49,14.9 \%$ of the total) and in the highest age-group (> 75 years, $n=45,13.7 \%$ of the total) were compared in terms of the significant variables. LBM, MES and MGS were lower for the highest age-group by $4.9 \%$ ( $p=0.049), 29.9 \%$ and $24.3 \%(p<0.001)$, respectively, while TUGT increased by $39.0 \%(p<0.001)$. 
Table 2 Descriptive data of the study population $(n=329)$.

\begin{tabular}{lllc}
\hline & Mean & $\mathrm{SD}^{\mathrm{a}}$ & Interquartile range \\
\hline BMD lumbar spine $\left(\mathrm{g} / \mathrm{cm}^{2}\right)$ & 0.937 & 0.170 & $0.817-1.035$ \\
BMD femoral neck $\left(\mathrm{FN}, \mathrm{g} / \mathrm{cm}^{2}\right)$ & 0.851 & 0.141 & $0.756-0.944$ \\
Age (years) & 66.9 & 6.51 & $61.4-71.5$ \\
Postmenopausal years & 20.1 & 8.09 & $14.0-26.0$ \\
Body mass index $\left(\mathrm{BMI}, \mathrm{kg} / \mathrm{m}^{2}\right)$ & 27.6 & 4.57 & $24.7-29.7$ \\
Total lean body mass $(\mathrm{LBM}, \mathrm{kg})$ & 41.8 & 4.90 & $38.4-44.9$ \\
Maximum quadriceps extension strength & 23.4 & 7.77 & $17.8-28.0$ \\
(MES, kg) & 26.4 & 5.90 & $22.0-30.0$ \\
Maximum handgrip strength (MGS, kg) & 13.4 & 7.78 & $9.90-14.6$ \\
\hline Timed up and go test (TUGT, sec) & & & \\
\hline
\end{tabular}

a $\mathrm{SD}=$ standard deviation

Table 3 Relationship ${ }^{a}$ between physical characteristics and age $(n=329)$.

\begin{tabular}{lcr} 
& \multicolumn{2}{c}{ Age (years) } \\
\cline { 2 - 3 } & $r$ & $p$ \\
\hline BMD lumbar spine $\left(\mathrm{g} / \mathrm{cm}^{2}\right)$ & -0.152 & 0.006 \\
BMD femoral neck $\left(\mathrm{FN}, \mathrm{g} / \mathrm{cm}^{2}\right)$ & -0.290 & $<0.001$ \\
Body mass index $\left(\mathrm{BMI}, \mathrm{kg} / \mathrm{m}^{2}\right)$ & -0.053 & 0.348 \\
Total lean body mass $(\mathrm{LBM}, \mathrm{kg})$ & -0.166 & 0.003 \\
Maximum quadriceps extension strength (MES, kg) & -0.318 & $<0.001$ \\
Maximum handgrip strength (MGS, kg) & -0.356 & $<0.001$ \\
Timed up and go test (TUGT, sec) & 0.282 & $<0.001$ \\
\hline
\end{tabular}

${ }^{a}$ List of abbreviations

All three values of binding $(6,10$, and 16) of cFTs, cBaTs, FTRs and BTRs were significantly correlated (range $r: 0.981$ to $0.998, p<0.001$ ). Therefore, we only present the data for a KTS of 10 , which is the value used by Vermeulen et al. ${ }^{3}$

The descriptive data of the hormone concentrations and bone turnover markers (BTM) are presented in Table 4, while Table 5 presents the relation between hormones and BTM and age. FTR10, BTR10, and ESR, significantly decreased with ageing, while DPyr significantly increased with ageing. Again, women in the lowest age-group were compared with the highest age-group in terms of the significant variables. FTR10, BTR10 and ESR were lower for the highest agegroup by $14.8 \%, 14.8 \%$ and $22.4 \%$, respectively, while DPyr increased by $16.7 \%$.

Because cBaT is based on cFT, the correlation is perfect, as those for BTR and FTR ( $r$ : 1.00, $p<0.001)$. Therefore, we only used the values of cFT and FTR and not those of cBaT and BTR in our further analysis. 
Table 4 Summed values of hormone levels in serum $(n=329){ }^{a}$

\begin{tabular}{|c|c|c|c|}
\hline & Mean & $S D^{a}$ & Interquartile range \\
\hline $\begin{array}{l}\text { Sex-hormone binding globulin } \\
\text { (SHBG, nmol/L) }\end{array}$ & 53.3 & 30.2 & $34.4-63.0$ \\
\hline \multicolumn{4}{|l|}{ Testosterone } \\
\hline Total testosterone (TT, nmol/L) & 1.50 & 0.959 & $0.689-2.00$ \\
\hline Free androgen index (FAI, \% M/M) & 3.66 & 3.41 & $1.54-4.53$ \\
\hline $\begin{array}{l}\text { Calculated free testosterone } \\
\text { (cFT10, pmol/L) }\end{array}$ & 22.4 & 17.4 & $10.7-28.2$ \\
\hline $\begin{array}{l}\text { Calculated bioavailable testosterone } \\
\text { (cBaT10, nmol/L) }\end{array}$ & 0.524 & 0.407 & $0.252-0.661$ \\
\hline FTR10 (\% M/M) & 1.49 & 0.487 & $1.17-1.76$ \\
\hline BTR10 (\% M/M) & 34.9 & 11.4 & $27.3-41.2$ \\
\hline \multicolumn{4}{|l|}{ Estrogen } \\
\hline Estradiol $\left(\mathrm{E}_{2}, \mathrm{pmol} / \mathrm{L}\right)$ & 84.9 & 47.5 & $73.4-73.4^{b}$ \\
\hline $\mathrm{E}_{2} / \mathrm{SHBG}$ ratio (ESR, $\left.\mathrm{pM} / \mathrm{nM}\right)$ & 2.06 & 1.49 & $1.22-2.26$ \\
\hline \multicolumn{4}{|l|}{ Bone turnover markers } \\
\hline Osteocalcine (OC, mgram/L) & 3.47 & 2.32 & $1.68-4.70^{c}$ \\
\hline DPyr (nM/mM) & 6.29 & 2.34 & $4.87-7.24$ \\
\hline
\end{tabular}

a $\mathrm{SD}=$ standard deviation

b All values $<73.4$ were set at $73.4 \mathrm{pmol} / \mathrm{L}$

c All values $<1.00$ were set at $0.99 \mathrm{mgram} / \mathrm{L}$

Table 5 Relationship between age and hormone levels $(n=329)$.

\begin{tabular}{|c|c|c|}
\hline & \multicolumn{2}{|c|}{ Age (years) } \\
\hline & $r$ & $p$ \\
\hline $\begin{array}{l}\text { Sex-hormone binding globulin } \\
\text { (SHBG, nmol/L) }\end{array}$ & 0.091 & 0.102 \\
\hline \multicolumn{3}{|l|}{ Testosterone } \\
\hline Total testosterone (TT, nmol/L) & 0.034 & 0.540 \\
\hline Free androgen index (FAI, \% M/M) & -0.080 & 0.153 \\
\hline $\begin{array}{l}\text { Calculated free testosterone } \\
\text { (cFT10, pmol/L) }\end{array}$ & -0.043 & 0.438 \\
\hline $\begin{array}{l}\text { Calculated bioavailable testosterone } \\
\text { (cBaT10, nmol/L) }\end{array}$ & -0.043 & 0.438 \\
\hline FTR10 (\% M/M) & -0.142 & 0.011 \\
\hline BTR10 (\% M/M) & -0.142 & 0.011 \\
\hline \multicolumn{3}{|l|}{ Estrogen } \\
\hline Estradiol $\left(\mathrm{E}_{2}, \mathrm{pmol} / \mathrm{L}\right)$ & -0.007 & 0.901 \\
\hline $\mathrm{E}_{2} / \mathrm{SHBG}$ ratio (ESR, $\left.\mathrm{pM} / \mathrm{nM}\right)$ & -0.141 & 0.011 \\
\hline \multicolumn{3}{|l|}{ Bone turnover markers } \\
\hline Osteocalcine (OC, mgram/L) & 0.050 & 0.372 \\
\hline DPyr (nM/mM) & 0.135 & 0.015 \\
\hline
\end{tabular}

a List of abbreviations 
After age-adjustment, BMI was not significantly related to either MES (partial $r$ : $0.102, p=0.08$ ) or MGS (partial $r:-0.044, p=0.423$ ), but was significantly related to TUGT (partial $r: 0.154, p<0.01$ ). Almost all measurements of $T$ and $E$ were significantly related to body mass index (BMI) after age-adjustment (partial $r: 0.075, p=0.178$, for TT; partial $r: 0.215, p<0.001$, for FAI, partial $r: 0.272, p<0.001$, for cFT10; partial $r: 0.373, p<0.001$, for FTR10).

Almost all relations between SHBG, TT, FAI cFT10, and FTR10 were significantly related to each other. The relations between SHBG and FAI, CFT10 or FTR10 were significantly negatively related (range partial $r:-0.870$ to -0.440 , $p<0.001$ ), and all other relations were significantly positively related (range partial $r: 0.458$ to $0.947, p<0.001$ ).

The relations between $\mathrm{E}_{2}$ and SHBG (partial $r$ : 0.187), ESR and SHBG (partial $r:$-0.556), ESR and FAI (partial $r:$ 0.532), ESR and cFT10 (partial $r$ : 0.330), and ESR and FTR10 (partial $r$ : 0.789) were also significant $(p<0.001)$. As regards testosterone, higher values of FAI, cFT10 and FTR10 significantly increased LBM, while higher values of FAI and cFT10 significantly increased MES, after age-adjustment (Table 6). As regards estrogen, only higher values of ESR significantly increased LBM; it was not significantly related to the other muscle strength parameters (Table 6). In addition, higher values of the BTM osteocalcin significantly decreased LBM (partial $r:-0.117, p<0.05$ ), while higher values of DPyr significantly decreased MGS (partial $r$ : -0.149 , $p<0.01$ ) and significantly increased TUGT (partial $r: 0.126, p<0.05$ ).

\section{The relation of $\mathrm{T}, \mathrm{E}$ and $\mathrm{BTM}$ with bone}

After adjustment for age, higher values of FAI, cFT10, FTR10, $E_{2}$, and ESR significantly increased BMD measured at the lumber spine and at the femoral neck (Table 6).

Of the BTMs, higher values of OC significantly declined BMD measured at the lumber spine (partial $r=-0.132, p<0.05$ ) and at the femoral neck (partial $r=-0.118, p<0.05)$. 


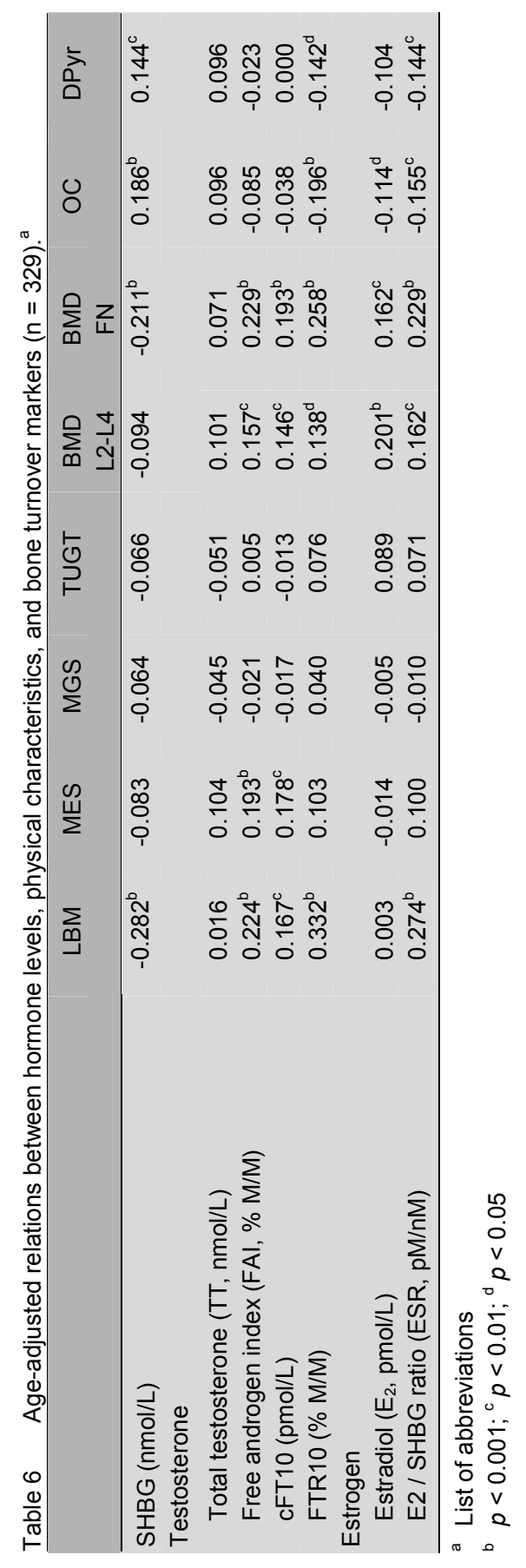




\section{Discussion}

The results show that age-related loss of LBM, MES and BMD is partly dependent on the presence of endogenous bioavailable testosterone $(T)$ and estrogen (E) concentrations.

In contrast to the well-documented relations of $E$ and $T$ with BMD in women and men and with muscle strength and mass in men, not much attention has been given to the relations of $T$ and $E$ with muscle mass and muscle strength in postmenopausal women. ${ }^{15,17} \mathrm{~A}$ study involving 20 women aged between 43 and 73 years old found a significant relation between $\mathrm{fT}$ and muscle mass and strength. ${ }^{16}$ Another study found that 46 postmenopausal women aged between 46 and 55 years old who used estrogens had decreased bioavailable $T$ and that this decrease was related to a decrease in LBM. ${ }^{23}$ In our population of 329 postmenopausal women the age-related decreases in LBM, MES and BMD in spine and FN were related to bioavailable $T$ (FAl, FTR) and $E_{2}$ (ESR).

\section{Changes in $\mathrm{T}, \mathrm{E}$, muscle mass, muscle strength and BTM with age}

TT and TE did not change significantly with aging in our study. Cappola found a decrease in TT until the age of 80 years, but similar values in $80+$ compared to 65-68 years-old women, and no significant relation with the number of years since menopause. ${ }^{15}$ Risk factors for low $T$ have been documented in women aged 65 years and older and include bilateral oophorectomy, estrogen use, corticosteroid use and low BMI. ${ }^{15}$ We found significant relations between bioavailable $\mathrm{T}$ and $\mathrm{E}$ and $\mathrm{BMI}$.

Although, bioavailable E (ESR) and T (FTR and BTR) decreased with age, FAl, which is considered a reliable index of $\mathrm{fT},{ }^{3}$ did not change with age, as was also found by Cappola who measured fT directly by dialysis. ${ }^{15}$

As expected, we found significant loss of LBM, MES, MGS and BMD in the spine and hip and an increase in TUGT with increasing age. The loss of MES $(-30 \%)$ and MGS $(-24 \%)$ between the ages of $<60$ years and $>75$ years was much more pronounced than the loss of LBM $(-5 \%)$, indicating also a decrease in muscle efficiency with aging. ${ }^{24}$ Such losses of muscle mass and strength results in sarcopenia, which is a risk factor for falls and decreased quality of life. $^{24}$ 
Bone resorption (DPyr) increased with age, as has also been found by others. ${ }^{7}$ OC did not change significantly, while others found an increase in OC with age, but with unchanged serum bone alkaline phosphatase (BAP) and serum carboxyl-terminal propeptide of type I collagen (PICP). ${ }^{7}$

\section{Relations of T and E with muscle mass and muscle strength}

LBM and MES were significantly related to FAI and ESR. However, our ageadjusted analysis found FAI to be related to both LBM and MES, while ESR was only related to LBM. In addition, MES was independently related to LBM and $\mathrm{FAI}$, but not to ESR. This indicates that muscle mass depends on $T$ and $E$, while muscle strength depends only on $\mathrm{T}$.

Although the effect of $\mathrm{T}$ administration on muscle is variable, several intervention studies have reported that it leads to increased LBM, muscle size and maximum voluntary strength in elderly men. ${ }^{13}$ The effect of $T$ and $E$ on muscle in postmenopausal women is still unclear. ${ }^{17}$ One confounder in the search for the relation between $E$ and muscle in intervention studies is the finding that estrogen replacement in postmenopausal women leads to decreased $T$ concentrations, and this decrease in $T$ is associated with a decreased LBM. ${ }^{17}$ By contrast, the combination of $\mathrm{T}$ and $\mathrm{E}$ leads to increased muscle mass. ${ }^{13}$

Unlike MES, MGS was not significantly related to any total or bioavailable $\mathrm{T}$ or $E$ values. This is surprising, as MES, MGS and LBM were highly intercorrelated. The decrease in muscle mass, strength and power with aging is caused by atrophy of muscle fibres, particularly those of type Ila. T binds to the androgen receptor in muscle tissue and stimulates protein synthesis in both type I (fast, anaerobic) and type II (slow, aerobic) muscle fibres. It is possible that the differences in the association of T with MES and MGS are the result of a greater effect of $T$ in the most disused muscle, i.e. the quadriceps, in which the loss of maximum strength has been found to be $49 \%$ larger than the loss of MGS. ${ }^{25}$ Another possibility is that androgens mainly affect proximal limb muscles. Proximal muscle weakness is a typical clinical feature of Kennedy's disease, a genetic neurodegenerative disorder related to the androgen receptor, and in a knock-out animal model of this disease, mutant males exhibited androgen-dependent neuromuscular weakness. ${ }^{26}$ These findings suggest that measuring proximal limb muscle strength such as MES is mandatory in prospective studies of the effect of $E$ and $T$ on muscle strength. 
No relation was found between $T$ and $E$ and TUGT, although TUGT was significantly related to LBM and MES. TUGT is, however, not only dependent on muscle mass and strength but also on coordination and balance. In a recent study in elderly men T supplementation did increase LBM but without any effect on TUGT. ${ }^{27}$ Additional studies will be needed to analyse the relation between $T$ and $E$ and muscular functional repercussions.

\section{Relation of $\mathrm{T}$ and $\mathrm{E}$ with bone}

The results of our study confirm the known relations between bone and circulating $\mathrm{E}$ and $\mathrm{T}$ in postmenopausal women. ${ }^{8}$ Circulating $\mathrm{E}$ and $\mathrm{T}$ levels are associated with $\mathrm{BMD}^{6,7}$ and bone size at most skeletal locations. ${ }^{5}$ Circulating $\mathrm{E}$ levels are also related to hip fracture risk and height loss, ${ }^{28}$ but not to vertebral fractures. ${ }^{29}$ We found that both FAI and ESR were independently related to FN $\mathrm{BMD}$, as has also been reported by others for postmenopausal women ${ }^{7}$ and in elderly men. ${ }^{4}$ Prospective studies in elderly men indicate that $T$ is an independent risk factor for future fracture, but data for women are not available.

BTMs (OC and DPyr) were negatively related to ESR and FTR, but not significantly to $\mathrm{FAl}$. This relation has also been found by others for $E$ and $T$ levels. ${ }^{7}$ These data confirm that low $E$ and $T$ are related to increased bone turnover in postmenopausal women, which is a risk factor for fractures. ${ }^{30,31}$ The data suggest that the relation between BMD and $E$ and $T$ is in part mediated by the level of bone turnover. Indeed, we found OC to be negatively related to $\mathrm{BMD}$ in the spine and FN.

The pluripotent effects of $T$ and $E$ on bone and muscle open up new avenues for further research into interventions to increase muscle mass and strength. One option would be the development of selective androgen receptor modulators (SARMs), some of which have been shown to have potent anabolic effects on bone and muscle. ${ }^{13,32}$

This study was subjected to some limitations. First, it was a cross-sectional population-based study, and longitudinal studies will be necessary to confirm our conclusions. Second, the women in this study were aged between 55 and 85 years. No data were available on women aged 85 years and over. Third, no measured values of free $T$ and free $E$ were available, but only calculated free $T$ and free $\mathrm{E}$. 


\section{Conclusion}

We conclude that in postmenopausal women, age-related loss of LBM, MES (but not MGS) and BMD is partly dependent on the presence of endogenous bioavailable $T$ and $E$. In addition to the well-known effects on bone, bioavailable $\mathrm{T}$ and $\mathrm{E}$ seem to play a role in the loss of lean mass and muscle strength that occurs after menopause, although the cross-sectional nature of the study precludes a definitive conclusion. 


\section{References}

1. Sodergard R, Backstrom $T$, Shanbhag $V$, et al. Calculation of free and bound fractions of testosterone and estradiol-17 beta to human plasma proteins at body temperature. J Steroid Biochem 1982; 16(6): 801-10.

2. Dunn JF, Nisula BC, Rodbard D. Transport of steroid hormones: binding of 21 endogenous steroids to both testosterone-binding globulin and corticosteroid-binding globulin in human plasma. J Clin Endocrinol Metab 1981; 53(1): 58-68.

3. Vermeulen A, Verdonck L,Kaufman JM. A critical evaluation of simple methods for the estimation of free testosterone in serum. J Clin Endocrinol Metab 1999; 84(10): 3666-72.

4. Beld van den AW, Jong de FH, Grobbee DE, et al. Measures of bioavailable serum testosterone and estradiol and their relationships with muscle strength, bone density, and body composition in elderly men. J Clin Endocrinol Metab 2000; 85(9): 3276-82.

5. Khosla S, Riggs BL. Pathophysiology of age-related bone loss and osteoporosis. Endocrinol Metab Clin North Am 2005; 34(4): 1015-30.

6. Greendale GA, Edelstein S,Barrett Connor E. Endogenous sex steroids and bone mineral density in older women and men: the Rancho Bernardo Study. J Bone Miner Res 1997; 12(11): 1833-43.

7. Khosla S, Melton LJ, 3rd, Atkinson EJ, et al. Relationship of serum sex steroid levels and bone turnover markers with bone mineral density in men and women: a key role for bioavailable estrogen. J Clin Endocrinol Metab 1998; 83(7): 2266-74.

8. Vanderschueren D, Vandenput L, Boonen S, et al. Androgens and bone. Endocr Rev 2004; 25(3): 389-425.

9. Lufkin EG, Wahner HW, O'Fallon WM, et al. Treatment of postmenopausal osteoporosis with transdermal estrogen. Ann Intern Med 1992; 117(1): 1-9.

10. Snyder PJ, Peachey $H$, Hannoush $P$, et al. Effect of testosterone treatment on body composition and muscle strength in men over 65 years of age. J Clin Endocrinol Metab 1999; 84(8): 2647-53.

11. Herbst KL, Bhasin S. Testosterone action on skeletal muscle. Curr Opin Clin Nutr Metab Care 2004; 7(3): 271-7.

12. Bhasin S, Calof OM, Storer TW, et al. Drug insight: Testosterone and selective androgen receptor modulators as anabolic therapies for chronic illness and aging. Nat Clin Pract Endocrinol Metab 2006; 2(3): 146-59.

13. Chen J, Kim J,Dalton JT. Discovery and therapeutic promise of selective androgen receptor modulators. Mol Interv 2005; 5(3): 173-88.

14. Ferrando AA, Sheffield Moore M, Yeckel CW, et al. Testosterone administration to older men improves muscle function: molecular and physiological mechanisms. Am J Physiol Endocrinol Metab 2002; 282(3): E601-7.

15. Cappola AR, Ratcliffe SJ, Bhasin S, et al. Determinants of serum total and free testosterone levels in women over the age of 65 years. J Clin Endocrinol Metab 2007; 92(2): 509-16.

16. Hakkinen K, Pakarinen A. Muscle strength and serum testosterone, cortisol and SHBG concentrations in middle-aged and elderly men and women. Acta Physiol Scand 1993; 148(2): 199-207.

17. Padero MC, Bhasin S,Friedman TC. Androgen supplementation in older women: too much hype, not enough data. J Am Geriatr Soc 2002; 50(6): 1131-40.

18. Sands R, Studd J. Exogenous androgens in postmenopausal women. Am J Med 1995; 98(1a): 76s-9s. 
19. Pardridge WM. Serum bioavailability of sex steroid hormones. Clin Endocrinol Metab 1986; 15(2): 259-78.

20. Voort van der DJM, Geusens PP, Dinant GJ. Risk factors for osteoporosis related to their outcome: fractures. Osteoporos Int 2001; 12: 630-8.

21. Podsiadlo $D$, Richardson S. The timed "Up \& Go": a test of basic functional mobility for frail elderly persons. J Am Geriatr Soc 1991; 39(2): 142-8.

22. Field A. Discovering statistics using SPSS for Windows. 2000, Trowbridge: The Cromwell Press Ltd.

23. Gower BA, Nyman L. Associations among oral estrogen use, free testosterone concentration, and lean body mass among postmenopausal women. J Clin Endocrinol Metab 2000; 85(12): 4476-80.

24. Morley JE, Baumgartner RN, Roubenoff R, et al. Sarcopenia. J Lab Clin Med 2001; 137(4): 231-43.

25. Lynch NA, Metter EJ, Lindle RS, et al. Muscle quality. I. Age-associated differences between arm and leg muscle groups. J Appl Physiol 1999; 86(1): 188-94.

26. Yu Z, Dadgar N, Albertelli M, et al. Androgen-dependent pathology demonstrates myopathic contribution to the Kennedy disease phenotype in a mouse knock-in model. J Clin Invest 2006; 116(10): 2663-72.

27. Emmelot Vonk MH, Verhaar HJ, Nakhai Pour HR, et al. Effect of testosterone supplementation on functional mobility, cognition, and other parameters in older men: a randomized controlled trial. JAMA 2008; 299(1): 39-52.

28. Cauley JA, Black DM, Barrett Connor E, et al. Effects of hormone replacement therapy on clinical fractures and height loss: The Heart and Estrogen/Progestin Replacement Study (HERS). Am J Med 2001; 110(6): 442-50.

29. Nevitt MC, Cummings SR, Stone KL, et al. Risk factors for a first-incident radiographic vertebral fracture in women $>$ or $=65$ years of age: the study of osteoporotic fractures. $\mathrm{J}$ Bone Miner Res 2005; 20(1): 131-40.

30. Garnero P, Delmas PD. Bone markers. Bailliere's Clin Rheumatol 1997; 11(3): 517-37.

31. Garnero P, Hausherr E, Chapuy MC, et al. Markers of bone resorption predict hip fracture in elderly women: the EPIDOS Prospective Study. J Bone Miner Res 1996; 11(10): 1531-8.

32. Wilson EM. Muscle-bound? A tissue-selective nonsteroidal androgen receptor modulator. Endocrinology 2007; 148(1): 1-3. 
Chapter 7
General discussion
Gen

Chapter 7
General discussion

Chapter 7
General discussion

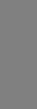

(n)




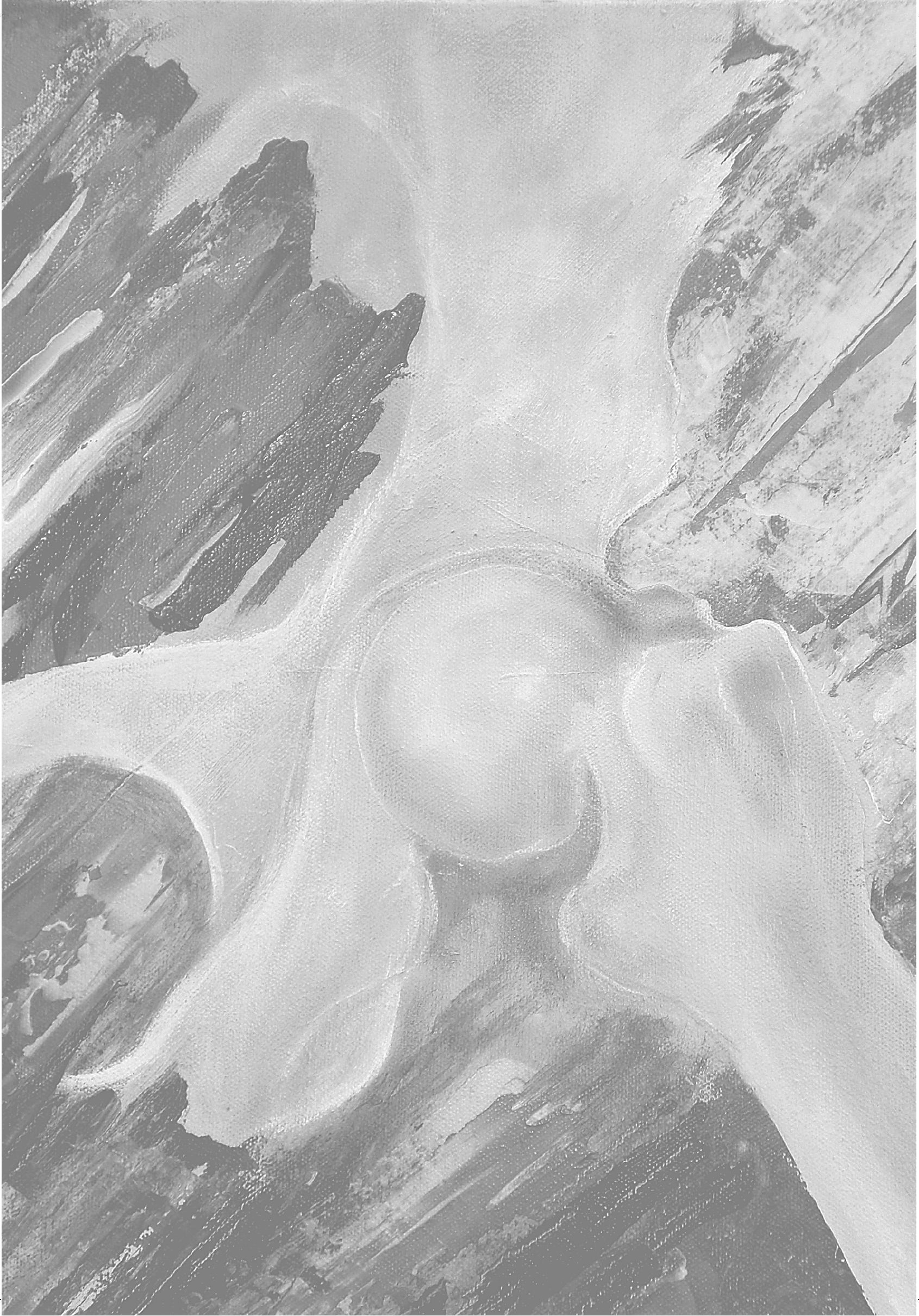


110 Chapter 7 


\section{General discussion}

his chapter discusses the main results of the studies and their and suggestions for further research.

The first main finding discussed in this dissertation is that clinical vertebral and non-vertebral fractures in women cluster in time from menopause onwards. It has been known for a long time that having a history of non-vertebral fracture is associated with a doubling of the risk of a subsequent fracture. ${ }^{1}$ However, we have shown that this re-fracture risk is not constant, but fluctuates over time and is caused by the high, 3- to 5 -fold increase in the years immediately after the first fracture, followed by a gradual waning off. Surprisingly, the first clues of the clustering of fractures were even found in the relatively small group of 759 women we followed over 5 years, indicating the strength of the association. We were able to substantiate earlier observations of clustering of fractures, relating to selected locations ${ }^{2}$ or to women and men aged 60 years and older, ${ }^{3}$ and extend them to all postmenopausal women, with any clinical fracture, and from menopause onwards.

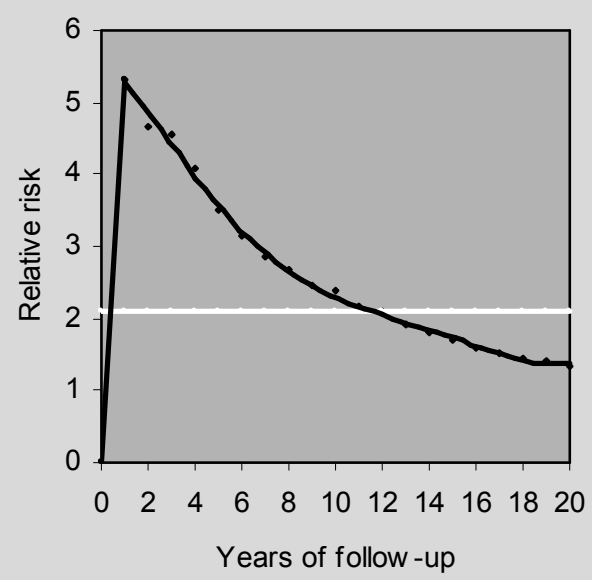

Figure 1 Relative risk of all subsequent fractures calculated as a mean from the first fracture (white line) or per separate year of follow-up (black line).

The clustering of fractures is illustrated in Figure 1. The horizontal line indicates the doubling of the risk of subsequent fractures as found in the literature and in our studies, calculated as a mean without taking into account the relation in time between the first and subsequent fractures. When calculated as a mean the 
relative risk (RR) from the time of first fracture onwards remains constant, as we and others have confirmed. ${ }^{1,4}$

The curve indicates the time-dependent RR taking into account the time since first fracture. It shows that the doubling of the fracture risk is caused by the early significant 3- to 5-fold increase, which wanes off after 5 years, and is even below 1.0 later on. Thus, the RR is significantly increased over the $0-1$ and 2-5 year periods after the first fracture, but is decreased after 6 years. This last finding could be related to survival of the fittest ${ }^{3}$, but this remains to be confirmed by further studies.

The Dutch guideline on osteoporosis $(C B O)^{5}$ and the recently released FRAX ${ }^{\mathrm{TM}}$ algorithm of the World Health Organisation (WHO $)^{4}$ are based on the assumption of a stable risk of subsequent fracture over time. The clinical consequence of this guideline and algorithm is that patients with a fracture history need to have their fracture risk evaluated. However, the fluctuations in the fracture risk found in our studies have an even more urgent clinical consequence. Since 1 in 4 of all subsequent fractures occur within one year after the first fracture and half within 5 years, immediate action is necessary in postmenopausal women with a first fracture after menopause, to prevent a subsequent fracture. Our results indicate that this regards any first fracture from menopause onwards, even so-called 'minor' first fractures, as many subsequent fractures were found to involve hip and other major fractures. Definitions of fracture categories vary in the literature. Center et al. ${ }^{3}$ based their definition of major fractures (clinical vertebral, pelvis, distal femur, proximal tibia, multiple rib and proximal humerus) and minor fractures (all remaining osteoporotic fractures, fingers and toes) on data on mortality and morbidity after such fractures, ${ }^{3}$ while the WHO algorithm defined a different group of fractures as major (hip, clinical vertebral, forearm, humerus), based on the availability of epidemiologic data. ${ }^{4}$ However, our data suggest that - in terms of subsequent fracture risk - all women with a first fracture, whether hip fracture, other major fracture (any of the above definitions) or even minor fracture, deserve attention to prevent subsequent fractures.

The second main finding is that women presenting with a clinical fracture are characterised by a mixture of bone- and fall-related risk factors. The Dutch osteoporosis guideline mainly focuses on clinical bone-related risks and bone mineral density (BMD), ${ }^{5}$ and does not include specific evaluation of fall risks. One exception is severe immobility, but its inclusion as a risk factor was mainly related to its negative effects on $B M D$, as it is proposed as one of the risks that contribute to an indication for bone densitometry. The second exception is that a history of fractures to some degree implies the presence of a fall risk, as most 
clinical fractures are the result of a fall, but again non-vertebral fractures are proposed in the guideline merely as an indication for bone densitometry. Vertebral fractures, on the other hand, are considered to be an indication for therapy without BMD measurement, but most vertebral fractures are not the result of a fall and occur without the clinical signs and symptoms of an acute fracture.

Our study indicates that many women presenting with a fracture are also at risk of falling. Fall risks have been shown to contribute to fracture risk independently of low $\mathrm{BMD}^{6}$ and to contribute more to hip fracture risk than the presence of low BMD. ${ }^{7}$ Our study suggests that concentrating on bone-related risks leads to underestimation of future fracture risk (Figure 2).

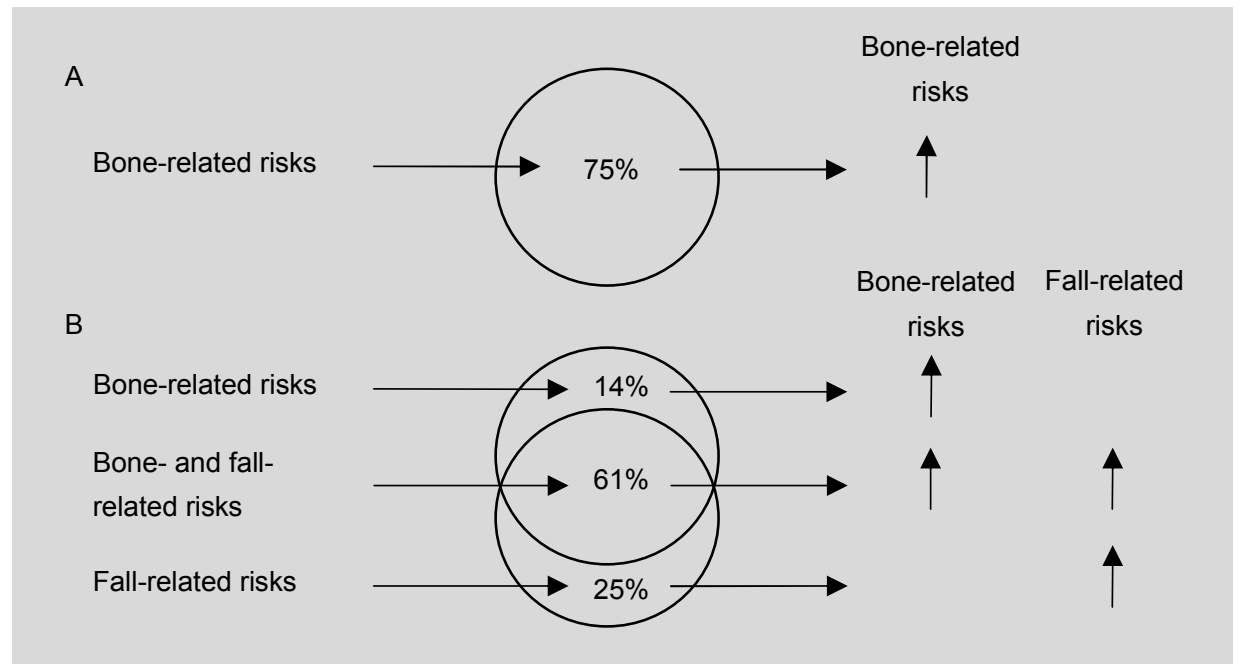

Figure 2 Distribution of bone- and fall related risk factors.

Based on of the Dutch guideline on osteoporosis, $75 \%$ of the women in our study had one or more bone-related risks, including BMD-osteoporosis (Figure $2 \mathrm{~A}$ ). However, only $17 \%$ of women would have been identified to be at risk before the fracture if the Dutch guideline on osteoporosis had been applied at that time. ${ }^{8}$ The main reasons were that the number of clinical risk factors or the combination of risk factors was insufficient to represent an indication for a BMD measurement, and that many women presenting with a fracture did not have osteoporosis, even if they already had a history of fracture. The WHO's FRAX algorithm is therefore a welcome extension of the approach to case finding for fracture risk, as it includes more risk factors for fractures. ${ }^{4}$ Compared with the Dutch guideline on osteoporosis, the following risk factors are additionally 
included in the FRAX algorithm: (1) gender, (2) age, (3) current smoking, (4) alcohol intake of 3 or more units daily, (5) rheumatoid arthritis and (6) other causes of secondary osteoporosis. ${ }^{4,5}$ The algorithm focuses not on BMD but on the individual 10-year fracture risk.

However, the FRAX algorithm explicitly excludes fall risk factor evaluation, for which they cite several reasons. The first is that the cohort data used to create the model report falls in very different ways; therefore it was not possible to derive a standardised metric. Second, although plausible, pharmaceutical intervention has not been shown to reduce fracture risk in patients only selected on the basis of a fall history, and it is important that risk assessment models identify a risk that can be reduced by treatment. ${ }^{4,9,10}$ Fall prevention strategies, whether focusing on specific fall risks or targeting a broad spectrum of risks, have been shown to reduce the risk of falling and serious injuries, but none of the available studies demonstrated a reduction of fracture risk. However, this line of reasoning ignores the value of fall risk evaluation in identifying women who are at even higher risk of fractures than when fracture risk evaluation is based solely on bone-related risks. It can be argued that solid data about the relation between well-specified fall-related risks and fracture risk is lacking, which would be needed to calculate accurate 10-year fracture risk. Our data suggest that fall risk evaluation in addition to the evaluation of bone-related risks contributes to the identification of women at highest risk of fractures. Figure 2 shows that, if only the Dutch guideline on osteoporosis is used, $25 \%$ of the patients with fall risks are not identified as being at high risk (A). Similarly, if fall-related risk factors are not taken into account, the risk of a subsequent fracture is probably underestimated in $61 \%$ of the patients with a fracture who have both fall- and bone-related risk factors $(B)$. In contrast, if fall-related risks for fractures are taken into account as well as bone-related risks, both the increases in bone- and fall-related risk factors for subsequent fracture are identified as fracture risks, thus reflecting a more comprehensive fracture risk prediction (B). This has been shown in long-term studies on the risk of hip fractures, which found that both skeletal and non-skeletal risks predict the risk of hip fractures. ${ }^{11-16}$

The results of our study give some clues to answer the question why fractures cluster in time. Although several hypotheses have been put forward to explain the doubling of the risk of subsequent fractures, these did not take into account the fluctuations in the risk. The hypotheses include pre- and post-fracture boneand fall-related risks (Table 1). 
Table 1 Hypotheses on the etiology of early re-fracture risk.

\begin{tabular}{|c|c|}
\hline & References \\
\hline \multicolumn{2}{|l|}{ Bone-related risks } \\
\hline \multicolumn{2}{|l|}{ Pre-existing } \\
\hline \multicolumn{2}{|l|}{ Cellular activity } \\
\hline $\begin{array}{l}\text { (high bone resorption, osteocyte death, } \\
\text { osteoblast insufficiency) }\end{array}$ & Seeman et al. $2006^{17}$ \\
\hline \multicolumn{2}{|l|}{ Material properties } \\
\hline $\begin{array}{l}\text { (hypo mineralisation or homogenised mineralisation, } \\
\text { micro-cracks) }\end{array}$ & Bouxsein et al. $2008^{18}$ \\
\hline Disturbed micro-architecture & Bouxsein et al. $2008^{18}$ \\
\hline \multicolumn{2}{|l|}{ Post-fracture } \\
\hline High turnover bone loss by immobility & Sambrook et al. $2006^{19}$ \\
\hline \multicolumn{2}{|l|}{ Fall-related risks } \\
\hline \multicolumn{2}{|l|}{ Pre-existing } \\
\hline \multirow[t]{3}{*}{ Fall risks and falls } & Cummings et al. $1995^{7}$ \\
\hline & Graafmans et al. $1996^{20}$ \\
\hline & Van Helden et al. $2008^{8}$ \\
\hline Hip fracture co-morbidity & Cummings et al. $1995^{7}$ \\
\hline Low vitamin D levels (and / or calcium intake) & Bischoff-Ferrari et al. $2004^{21}$ \\
\hline \multicolumn{2}{|l|}{ Post-fracture } \\
\hline Frequent fallers & Van Helden et al. $2007^{22}$ \\
\hline Immobility, other complications & Van Helden et al. $2007^{22}$ \\
\hline
\end{tabular}

Clearly, bone-related risks contribute to the increased risk of subsequent fractures, but it is unclear how they could explain the very early and substantial five-fold increase in fracture risk within one year after the first fracture. A more plausible hypothesis is that fall risks and falls after a first fracture increase the risk of subsequent fracture by increasing the risk of subsequent falls. Indeed, patients with an early subsequent fracture are probably those who are recurrent fallers and/or who have co-morbidity that contributes to falls. Furthermore, patients presenting with a fracture could be at increased risk of falls because of pre-existent poor mobility, vitamin D deficiency (which is endemic in the elderly) and surgical procedures and plastering (especially after lower limb fractures). Our research group has previously shown that in $15 \%$ of the women presenting with a fracture a fall occurred within the next 3 months, and that this incidence is particularly high in women with pre-existing poor ADL skills. ${ }^{22}$

The last part of this dissertation focuses on muscle characteristics as components in fall risks: we show that loss of muscle mass and muscle strength after menopause is related to endogenous circulating estrogens and testosterone, and is one of the many possible contributors to mechanisms involved in fall risk. 
In conclusion, our data indicate that clinical fractures cluster in time and that extra-skeletal factors such as fall risks may contribute to this risk. Combining bone- and fall-related approaches is therefore not only a valuable approach to the early identification of women at highest risk of fractures in the context of case finding. It also strengthens the view that women presenting with a fracture deserve attention not only in terms of treating the bone-related aspects of subsequent fracture risk, but also in terms of fall prevention. Verifying this hypothesis, however, requires further studies.

\section{Strengths of the studies}

The 1992-94 baseline cohort was prospectively followed for periods of 5 and 10 years. At the 5- and 10-year follow-up, participants completed questionnaires, and we succeeded in collecting a large volume of data on a large cohort of postmenopausal women, which we managed to prospectively follow for many years.

Another strength of our studies is that we studied clinical fractures, which could be easily pinpointed in time, and that the study involved a large population followed over a long period of time. This resulted in almost 80000 patient years of follow-up, making it one of the largest available studies on this topic.

\section{Limitations}

The baseline study focused on possible risk factors for osteoporosis. Since a positive history of falls is not a risk factor for osteoporosis, it was not included in the baseline assessment. Five and ten years after the baseline assessment, the study focused on the occurrence of fractures and not on osteoporosis. Although a positive history of falls is a risk factor for fractures, ${ }^{23-32}$ the baseline assessment did not allow us to take a history of falls into account.

The clustering in time of fractures was investigated for clinical fractures and not for morphometric vertebral fractures. In 2 out of 3 patients with a morphometric vertebral fracture, $X$-rays are necessary to confirm the fracture, which means that X-rays would need to be performed every year to record the year of occurrence. Such follow-up was not available in our studies. 


\section{Recommendations for further research}

Based on these results, some recommendations for further research can be formulated.

First, we need more insight into the reasons why fractures cluster in time. According to our findings, such research should combine more sophisticated measurements of bone-related risks, including new imaging techniques (e.g. microcomputer tomography and magnetic resonance imaging (MRI)) with assessments of fall-related risks in a prospective study. Longitudinal studies, probably involving the use of fall diaries, will be necessary to evaluate the influence of fall prevention strategies on fractures.

Second, unravelling the relation between sex hormones, muscle characteristics and falls requires prospective studies with interventions using hormones or selective estrogen or androgen modulators with specific effect on muscle strength.

Third, the baseline measurements started approximately 15 years ago. It would be valuable to have additional measurements in all women of the original cohort who are still traceable and alive, to investigate whether the 10-year algorithm can also be used to predict the 15-year fracture risk or even the 20-year fracture risk. This would be a unique and relevant study, because the effect of medication on fracture prevention is not known over such a long period of follow-up. Therefore, data are required to analyse the risk factors for a fracture over 20 years.

Finally, the 5- and 10-year algorithms are based on postmenopausal women. However, the lifetime fracture risk in men aged 50 years and over is $20.7 \%$ (compared with $53.2 \%$ in women). ${ }^{33}$ Our results in postmenopausal women indicate that a population-based prospective cohort study in men older than 50 years should also combine risk factors related to osteoporosis, fractures and falls to explore to what degree clinical fractures among men also cluster in time, and to assess the relative importance of bone- and fall-related risks for first and subsequent fractures. 


\section{References}

1. Klotzbuecher CM, Ross PD, Landsman PB, et al. Patients with prior fractures have an increased risk of future fractures: a summary of the literature and statistical synthesis. $J$ Bone Miner Res 2000; 15(4): 721-7.

2. Johnell $\mathrm{O}$, Kanis JA, Oden A, et al. Fracture risk following an osteoporotic fracture. Osteoporos Int 2004; 15(3): 175-9.

3. Center JR, Bliuc D, Nguyen TV, et al. Risk of subsequent fracture after low-trauma fracture in men and women. JAMA 2007; 297(4): 387-94.

4. Kanis JA, Burlet $\mathrm{N}$, Cooper $\mathrm{C}$, et al. European guidance for the diagnosis and management of osteoporosis in postmenopausal women. Osteoporos Int 2008; 19: 399-428.

5. Kwaliteitsinstituut voor de Gezondheidszorg CBO. Osteoporose Tweede Herziene Richtlijn. 2002, Alphen aan de Rijn: Van Zuiden Communications BV.

6. Kwaliteitsinstituut voor de Gezondheidszorg СBO. Preventie van valincidenten bij ouderen. 2004; Available from: http://www.cbo.nl/product/richtlijnen/ folder20021023121843/valrichtlijn2004.pdf.

7. Cummings SR, Nevitt MC, Browner WS, et al. Risk factors for hip fracture in white women. N Engl J Med 1995; 332(12): 767-73.

8. Helden van S, Geel van ACM, Geusens PP, et al. Bone and fall-related fracture risks in women and men with a recent clinical fracture. J Bone Joint Surg Am 2008; 90(2): 241-8.

9. Hays J, Ockene JK, Brunner RL, et al. Effects of estrogen plus progestin on health-related quality of life. N Engl J Med 2003; 348(19): 1839-54.

10. Anderson GL, Limacher $M$, Assaf $A R$, et al. Effects of conjugated equine estrogen in postmenopausal women with hysterectomy: the Women's Health Initiative randomized controlled trial. JAMA 2004; 291(14): 1701-12.

11. Ensrud KE, Ewing SK, Taylor BC, et al. Comparison of 2 frailty indexes for prediction of falls, disability, fractures, and death in older women. Arch Intern Med 2008; 168(4): 382-9.

12. Ensrud KE, Ewing SK, Taylor BC, et al. Frailty and risk of falls, fracture, and mortality in older women: the study of osteoporotic fractures. J Gerontol A Biol Sci Med Sci 2007; 62(7): 744-51.

13. Wainwright SA, Marshall LM, Ensrud KE, et al. Hip fracture in women without osteoporosis. J Clin Endocrinol Metab 2005; 90(5): 2787-93.

14. Schwartz AV, Nevitt MC, Brown BW, Jr., et al. Increased falling as a risk factor for fracture among older women: the study of osteoporotic fractures. Am J Epidemiol 2005; 161(2): 180-5.

15. Nevitt MC, Cummings SR. Type of fall and risk of hip and wrist fractures: the study of osteoporotic fractures. J Am Geriatr Soc 1994; 42(8): 909.

16. Cummings SR, Nevitt MC. Non-skeletal determinants of fractures: the potential importance of the mechanics of falls. Study of Osteoporotic Fractures Research Group. Osteoporos Int 1994; 4 Suppl 1: $67-70$.

17. Seeman E, Delmas PD. Bone quality--the material and structural basis of bone strength and fragility. N Engl J Med 2006; 354(21): 2250-61.

18. Bouxsein ML. Bone structure and function. in $17^{\text {th }}$ IOF advanced training course on osteoporosis. 2008. Lyon.

19. Sambrook PN, Chen CJ, March L, et al. High bone turnover is an independent predictor of mortality in the frail elderly. J Bone Miner Res 2006; 21(4): 549-55.

20. Graafmans WC, Ooms ME, Hofstee HM, et al. Falls in the elderly: a prospective study of risk factors and risk profiles. Am J Epidemiol 1996; 143(11): 1129-36. 
21. Bischoff Ferrari HA, Dawson Hughes B, Willett WC, et al. Effect of Vitamin D on falls: a metaanalysis. JAMA 2004; 291(16): 1999-2006.

22. Helden van S, Wyers CE, Dagnelie PC, et al. Risk of falling in patients with a recent fracture. BMC musculoskeletal disorders ISE: 14712474 2007; 8: 55.

23. O'Loughlin JL, Robitaille Y, Boivin JF, et al. Incidence of and risk factors for falls and injurious falls among the community-dwelling elderly. Am J Epidemiol 1993; 137(3): 342-54.

24. Blake AJ, Morgan K, Bendall MJ, et al. Falls by elderly people at home: prevalence and associated factors. Age Ageing 1988; 17(6): 365-72.

25. Tinetti ME, Speechley M,Ginter SF. Risk factors for falls among elderly persons living in the community. N Engl J Med 1988; 319(26): 1701-7.

26. Tinetti ME, Williams CS. Falls, injuries due to falls, and the risk of admission to a nursing home. N Engl J Med 1997; 337(18): 1279-84.

27. Campbell AJ, Borrie MJ, Spears GF, et al. Circumstances and consequences of falls experienced by a community population 70 years and over during a prospective study. Age Ageing 1990; 19(2): 136-41.

28. Roudsari BS, Ebel BE, Corso PS, et al. The acute medical care costs of fall-related injuries among the U.S. older adults. Injury 2005; 36(11): 1316-22.

29. Schwab M, Roder F, Aleker T, et al. Psychotropic drug use, falls and hip fracture in the elderly. Aging (Milano) 2000; 12(3): 234-9.

30. DeGoede KM, Ashton Miller JA,Schultz AB. Fall-related upper body injuries in the older adult: a review of the biomechanical issues. J Biomech 2003; 36(7): 1043-53.

31. Laet de CE, Pols HA. Fractures in the elderly: epidemiology and demography. Baillieres Best Pract Res Clin Endocrinol Metab 2000; 14(2): 171-9.

32. Tinetti ME. Clinical practice. Preventing falls in elderly persons. N Engl J Med 2003; 348(1): 42-9.

33. Staa van TP, Dennison EM, Leufkens HG, et al. Epidemiology of fractures in England and Wales. Bone 2001; 29(6): 517-22. 


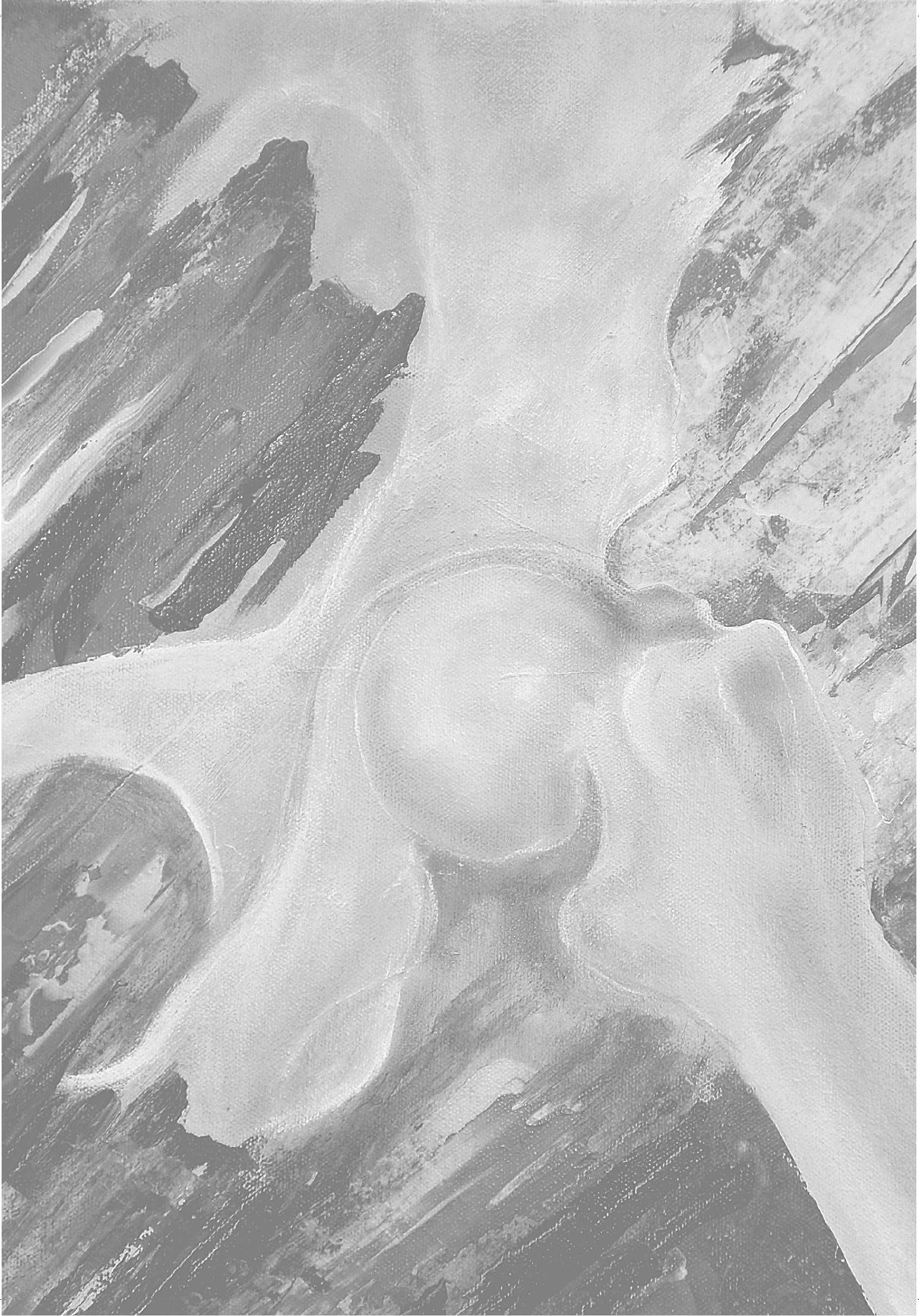


122 Chapter 8 


\section{Summary}

$\mathrm{F}$ ractures are a growing problem. It is estimated that 1 in 2 women will sustain a fracture during their remaining lifetime. Based on demographic changes, direct costs related to fractures are expected to more than double between the years 2000 and 2050. In view of this high economic burden and the fracture-related morbidity and mortality, it is important to identify patients who are at highest risk of fractures. We focused on clinical fractures, i.e. vertebral and non-vertebral fractures that result in clinical signs and symptoms of an acute fracture. This research project took a wide variety of risk factors into account to determine prognostic determinants of fractures in postmenopausal women in a population-based cohort of 4203 women aged between 50 and 80 years, who were prospectively followed in 12 general practices over a period of 10 years. The research questions in this dissertation concern bone-related as well as extra-skeletal risk factors for fractures:

1. What are the risk factors for a first or subsequent clinical fracture in postmenopausal women during long-term follow-up?

2. What is the time relation between a first and subsequent fracture in postmenopausal women?

3. What is the prevalence of bone- and fall-related risk factors in patients presenting with a first fracture?

4. What is the relation between age-related changes in muscle mass and muscle strength and age-related changes in endogenous circulating sex hormones in postmenopausal women?

Chapter 2 reports on a study on the risk of incident clinical fractures based on data available from a 5-year follow-up of a random sample of 759 women out of the original cohort of 4203 women. The aim was to construct a clinical algorithm based on the absolute 5-year fracture risk, which could be useful to detect postmenopausal women at high risk for clinical fractures. In total, 95 women $(12.5 \%)$ sustained a clinical fracture after baseline. A previous clinical fracture after menopause and a low bone mineral density (BMD, T-score $\leq-1.0$ ) were identified as significant predictors. In women with a history of fracture during the preceding 5 years, the absolute fracture risk was $50.1 \%$, which was significantly higher than the absolute risk of $21.2 \%$ in women who had a previous fracture that had occurred earlier. In women without a fracture history, the absolute risk was related to BMD and was $13.8 \%$ if BMD was low and $7.0 \%$ if BMD was normal. These results suggested that clinical fractures cluster in time. One in two women with a recent clinical fracture had a new clinical fracture within 5 years, regardless of BMD. The 5-year absolute risk of a first clinical fracture was much lower and depended on BMD. 
Based on the findings of the 5-year follow-up study, the objective of the study reported on in chapter 3 was to further elaborate on the construction of an algorithm to detect postmenopausal women at high risk of fractures, but in a larger population (2372 women) and with a longer follow-up (10 years). During the follow-up period, $380(16.0 \%)$ women sustained a fracture after baseline. Risk factors for a first fracture after baseline $(n=267(11.3 \%)$ women) were the presence of osteoporosis (T-score $\leq-2.5$ ) at baseline and increasing age. The resulting absolute risk was $9.8 \%$ in women younger than 60 years and without osteoporosis, and $23.0 \%$ in women older than 60 years with osteoporosis. In contrast, the only significant risk factor for a subsequent fracture was a history of fractures, independent of age and BMD. The absolute 5-year re-fracture risk was $41.4 \%$ if the previous fracture occurred during the previous 5 years and $25.1 \%$ if the previous fracture had occurred earlier. These results again suggested that the absolute risk of subsequent fractures is related in time to the occurrence of a previous fracture.

Chapter 4 analyses the time that elapses between a first and subsequent fracture in a long-term study from menopause onwards, since accurate data on the exact time of menopause were available at baseline. This analysis was based on an even longer follow-up period (up to 45 years after menopause, 79620 person-years). A first fracture after menopause occurred in 924 (22.3\%) women, 243 of whom (26.3\%) sustained a subsequent fracture. This analysis confirmed that clinical fractures cluster in time and allowed us to perform additional analyses to substantiate this increased risk. Compared with having a first fracture, the relative risk of subsequent fracture was double that of the first fracture. However, this increased long-term risk proved to be driven by a shortterm increase in risk, as the risk of subsequent fracture was increased five-fold in the first year after the first fracture and three-fold between 2 and 5 years after the first fracture, and was no longer increased more than 6 years after the first fracture. As a result, $23.0 \%$ of all subsequent fractures occurred within one year after the first fracture and $54.3 \%$ within 5 years, compared to $4.3 \%$ of all first fractures within any year from menopause onwards. The results indicate the need for early action after a first fracture to prevent subsequent fractures.

Most clinical vertebral and non-vertebral fractures are the result of traumatic accidents, and in the case of non-vertebral fractures such accidents mainly involve falls. Chapter 5 reports on a study investigating the prevalence of boneand fall-related risk factors in women and men aged over 50 who presented with a clinical vertebral or non-vertebral fracture. The examination was based on guidelines for osteoporosis and fall prevention used in the Netherlands. Osteoporosis of the hip or spine was found in $35 \%$ of women, clinical bone- 
related risks in $53 \%$ and clinical fall-related risks in $75 \%$. These risk factors overlapped and were heterogeneous, and were found in multiple combinations, regardless of patients' age or fracture location. These findings suggest that an integrated bone- and fall-related risk factor assessment is a useful method to identify elderly persons at high risk of fractures.

As part of the study on fall-related risks and fractures, we analysed muscle mass (by dual-energy absorptiometry) and muscle strength (in legs and forearm) in a subset of 329 women who were included in the 5-year follow-up (chapter 6). A comparison of the age categories $<60$ years and $>75$ years showed that lean body mass declined by $4.9 \%$, maximum quadriceps extension strength by $29.9 \%$ and maximum handgrip strength by $24.3 \%$, and scores on the timed up-and-go test increased by $39.0 \%$. We explored the relation between these muscle parameters and endogenous circulating sex hormones, which have been shown to be significantly related in elderly men, but are not well documented in postmenopausal women. The age-related loss of lean body mass and maximum quadriceps extension strength (but not handgrip strength) proved partly dependent on the presence of endogenous bioavailable testosterone and estrogens, although the cross-sectional nature of the study precluded a definitive conclusion.

In conclusion, our data indicate that clinical fractures cluster in time and that extra-skeletal factors such as fall risks may contribute to this risk. Combining a bone- and fall-related approach is therefore not only a valuable approach to the early identification of women at highest risk for fractures, in the context of case finding. It also implies that women with a fracture deserve immediate attention not only in terms of treating the bone-related aspects of subsequent fracture risk, but also in terms of addressing the fall-related aspects. 
-

पn-

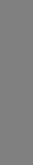

(1)
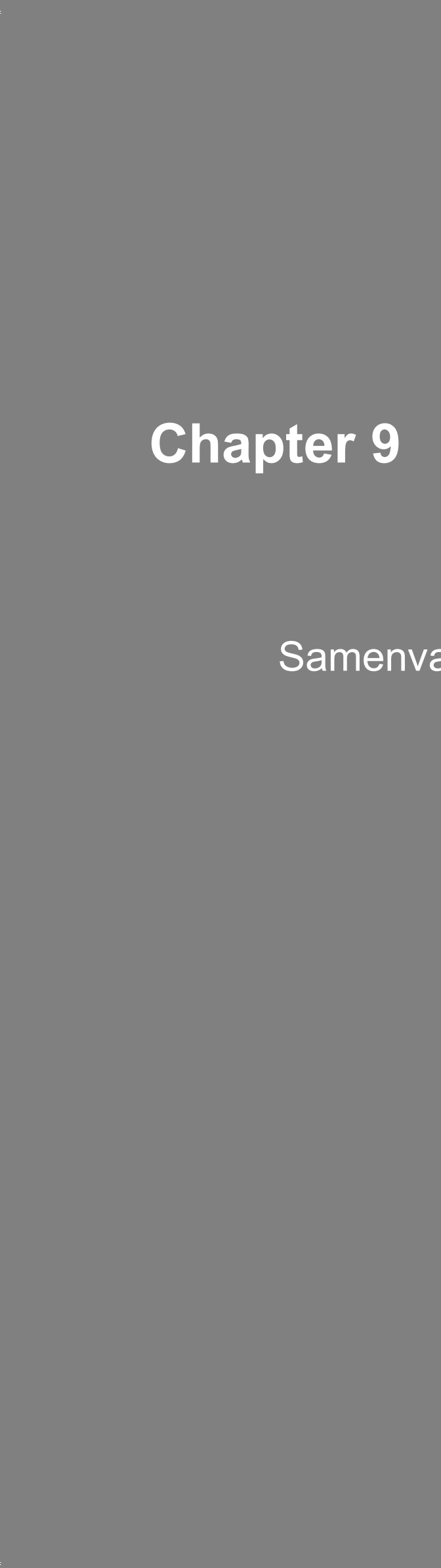


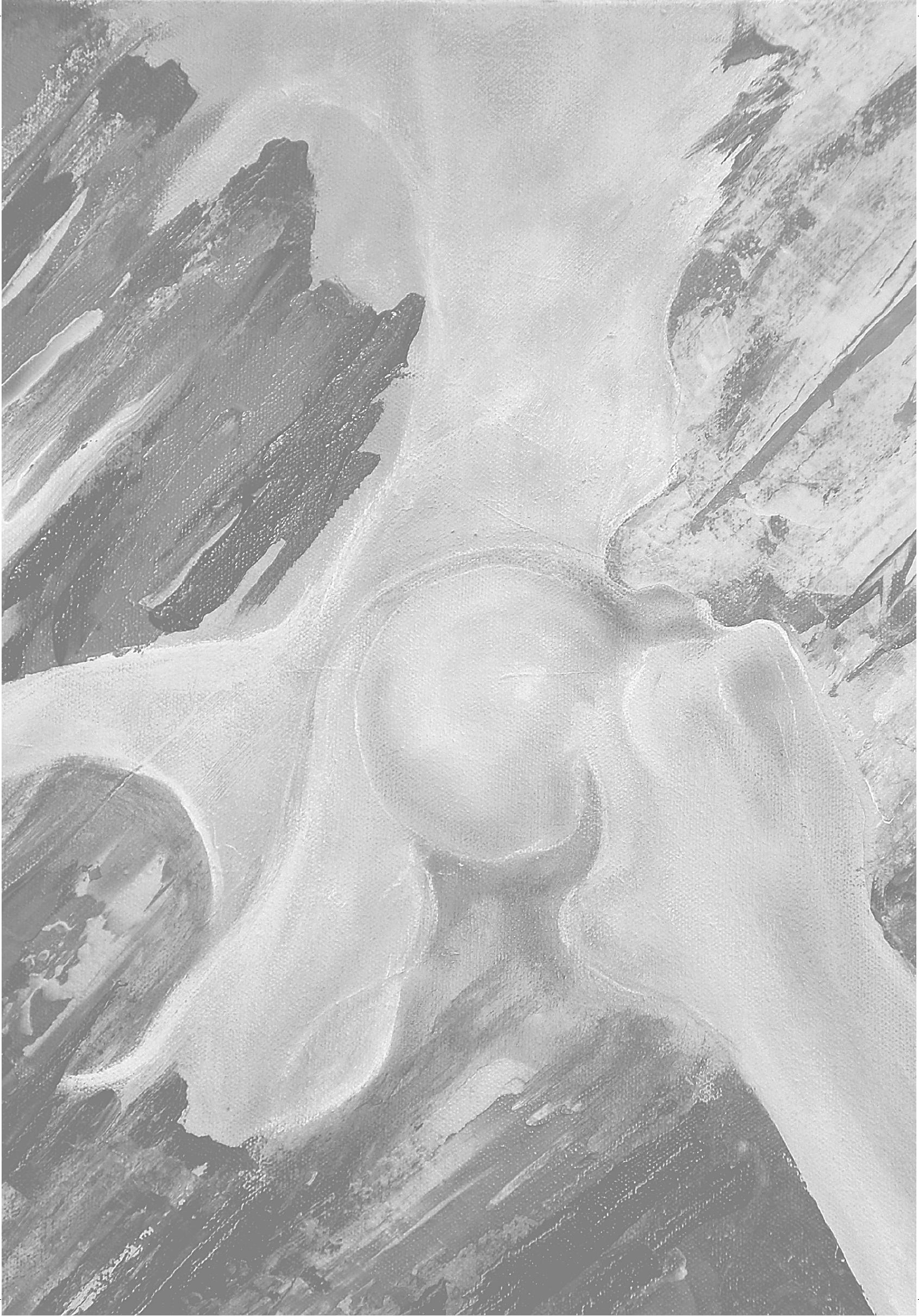




\section{Samenvatting}

W ede door de vergrijzing van onze bevolking vormen fracturen een toenemend gezondheidsprobleem. Dit zijn vooral de medische en maatschappelijke consequenties na het optreden van een heupfractuur bij de oudere patiënt. Denk aan de langdurige en zeer kostbare revalidatie na een heupfractuur en de blijvende bewegingsbeperking (afname van de mobiliteit die deels het gevolg is van valangst). In het jaar 2000 zijn naar schatting alleen al in Europa 3.8 miljoen osteoporotische fracturen opgetreden. De directe kosten werden geschat op $€ 36.2$ miljard en deze kosten zullen in 2050 verdubbeld zijn naar $€ 76.7$ miljard.

De studies die in dit proefschrift worden gepresenteerd richten zich op de vraag hoe huisartsen en specialisten kunnen voorspellen, in maat en getal, wat de kans is dat postmenopauzale vrouwen van 50 jaar en ouder binnen 5 tot 10 jaar na dato een fractuur oplopen. Het doel van het onderzoek is vierledig:

1. Onderzoeken, in een populatie van 4203 postmenopauzale vrouwen tussen de 50 en 80 jaar, welke risicofactoren het optreden van fracturen voorspellen binnen een termijn van 5 tot 10 jaar.

2. In ons onderzoek stelden we vast dat vrouwen een sterk verhoogd risico lopen op een fractuur kort na de voorafgaande fractuur. Daarom is het tweede deel van de studie gericht op het onderzoeken van de tijdsrelatie tussen een eerste en tweede fractuur.

3. Onderzoeken welke voorspellers van fracturen, die zowel bot- als valgerelateerd kunnen zijn, het meest frequent voorkomen bij ouderen op het moment dat een eerste fractuur is opgetreden.

4. Onderzoeken wat de relatie is tussen leeftijdsgerelateerde veranderingen in spiermassa, spierkracht en botmineraaldichtheid (BMD) enerzijds en de aan leeftijdgerelateerde veranderingen van geslachtshormonen anderzijds.

De resultaten die beschreven worden in dit proefschrift zijn voornamelijk gebaseerd op de gegevens van een 'population-based' cohort studie. Deze baseline studie vond plaats in 1992-94. In het cohort bestaande uit 4203 postmenopauzale vrouwen tussen de 50 en 80 jaar werd onderzocht welke determinanten osteoporose voorspellen. Tot de onderzochte variabelen behoren klinische, biometrische en radiologische variabelen. Vijf en 10 jaar na baseline werden aanvullende gegevens verzameld bij respectievelijk 759 en 2372 vrouwen om te onderzoeken welke determinanten het 5- en 10-jaarsrisico voor klinische fracturen voorspellen. 
In hoofdstuk 2 wordt een algoritme gepresenteerd betreffende het 5 -jaars fractuurrisico. De populatie $(n=759)$ bestond uit een aselecte steekproef uit het baseline cohort. In totaal hebben 95 vrouwen (12.5\%) een fractuur opgelopen na baseline. Uit de analyses blijkt dat een fractuur vóór baseline en een lage BMD (T-score $\leq-1.0$ ) voorspellers zijn voor een nieuwe fractuur. Het algoritme is gebaseerd op deze twee variabelen en laat zien dat één op de twee postmenopauzale vrouwen met een recente fractuur (opgelopen tijdens de afgelopen 5 jaar voor baseline) binnen 5-jaar na baseline een nieuwe fractuur kreeg die onafhankelijk was van de BMD. Van de vrouwen met in de voorgeschiedenis een fractuur die werd opgelopen langer dan 5-jaar voor baseline, kreeg één op de vijf vrouwen een volgende fractuur. De 5-jaars fractuurkans op een eerste fractuur is veel lager en is afhankelijk van de BMD: $13.8 \%$ bij een lage BMD en $7.0 \%$ bij een normale BMD.

In hoofdstuk 3 wordt een studie gepresenteerd die past bij de studie die beschreven is in hoofdstuk 2. De follow-up periode is nu tweemaal zo lang, de studiepopulatie is driemaal zo groot $(n=2372)$ en viermaal zoveel vrouwen kregen een fractuur na baseline ( $n=380,16.0 \%$ ). Deze studie bevestigt het belangrijkste resultaat dat wordt gepresenteerd in hoofdstuk 2 , namelijk dat vrouwen met een recente fractuur een veel grotere kans hebben op het ontwikkelen van een volgende fractuur. Twee op de vijf vrouwen (41.4\%) met een recente fractuur en één op de vier vrouwen $(25.1 \%)$ met een minder recente fractuur in de voorgeschiedenis kregen een volgende fractuur binnen 10 jaar na baseline. Het 10-jaars fractuurrisico voor een eerste fractuur is veel lager dan die voor een volgende fractuur en wordt bepaald door BMD en leeftijd: $9.8 \%$ bij vrouwen jonger dan 60 jaar zonder osteoporose (T-score > 2.5) en $23.0 \%$ bij vrouwen ouder dan 60 jaar met osteoporose.

Uit de voorafgaande hoofdstukken blijkt dat postmenopauzale vrouwen een ernstig verhoogd risico hebben op een nieuwe fractuur kort na de voorafgaande fractuur. In de studie gepresenteerd in hoofdstuk 4 wordt daarom de tijdsrelatie tussen fracturen onderzocht. Het onderzoek laat zien dat fracturen clusteren in tijd, want wij hebben gevonden dat $23.0 \%$ van alle tweede fracturen binnen één jaar na de eerste fractuur optreedt en $54.3 \%$ binnen vijf jaar. De kans op een tweede fractuur binnen één jaar is vijfmaal groter dan de kans op een eerste fractuur. De verhoogde kans op een tweede fractuur ten opzichte van de kans op de eerste fractuur blijft aanwezig tot 15 jaar na het optreden van de eerste fractuur. 
In hoofdstuk 5 worden de resultaten gepresenteerd van een studie bij 50 plussers, vrouwen en mannen, met een fractuur. De fractuurpatiënten waren opgenomen in het academisch ziekenhuis Maastricht (azM) of werden voor hun fractuur behandeld in het traumacentrum van het azM. Voor het vaststellen van de risicofactoren voor fracturen is gebruik gemaakt van de richtlijnen osteoporose en vallen van het kwaliteitsinstituut CBO (Centraal Begeleidings Orgaan). Uit het onderzoek blijkt dat zowel bot- als valgerelateerde risicofactoren aanwezig zijn. Van de patiënten had eenderde osteoporose, de helft minstens één botgerelateerde risicofactor, en driekwart minstens één valgerelateerde risicofactor. Dit houdt in dat zowel bot- als valgerelateerde risicofactoren belangrijk zijn voor het bepalen van het fractuurrisico. De resultaten zijn hetzelfde als gecorrigeerd wordt voor geslacht, leeftijd en fractuurlocatie.

In hoofdstuk 6 wordt de uitkomst beschreven van een cross-sectionele studie naar een relatie tussen leeftijdsgerelateerde veranderingen in spiermassa (gemeten met Dual X-ray absorptiometry) en spierkracht (handknijpkracht en quadriceps extensie kracht) enerzijds en leeftijdsgerelateerde veranderingen in de hoeveelheid geslachtshormonen (testosteron en oestrogeen) anderzijds. De resultaten laten zien dat de leeftijdsgerelateerde afname van spiermassa, spierkracht en BMD voor een deel afhankelijk is van testosteron- en oestrogeenniveaus. Als vrouwen jonger dan 60 jaar vergeleken worden met vrouwen ouder dan 75 jaar, blijkt dat de spiermassa afneemt met $5 \%$ en de spierkracht met 24-30\% (afhankelijk van de gebruikte test). De BMD neemt af met $7 \%$ en $12 \%$ (respectievelijk voor lumbale en femurhals BMD). Een longitudinale studie is nodig om de resultaten te bevestigen.

In hoofdstuk 7 worden de belangrijkste resultaten besproken. Er wordt een vergelijking gemaakt met soortgelijke studies die elders zijn uitgevoerd en de sterke en zwakke punten van het onderzoek worden toegelicht. Tot slot volgen aanbevelingen voor vervolgonderzoek. De belangrijkste bevindingen zijn dat klinische fracturen clusteren in de tijd en dat zowel bot- als valgerelateerde risicofactoren bijdragen aan het fractuurrisico. De clustering is een bevinding die voor de dagelijkse praktijk van de huisarts en specialist belangrijke consequenties heeft. Bij iedere postmenopauzale vrouw die door een arts wordt behandeld voor een fractuur (de betreffende patiënt behoort tot de groep vrouwen met de grootste kans op een volgende fractuur) moet zonder uitstel preventie van een volgende fractuur worden gestart, rekeninghoudend met zowel bot- als valgerelateerde aspecten. 


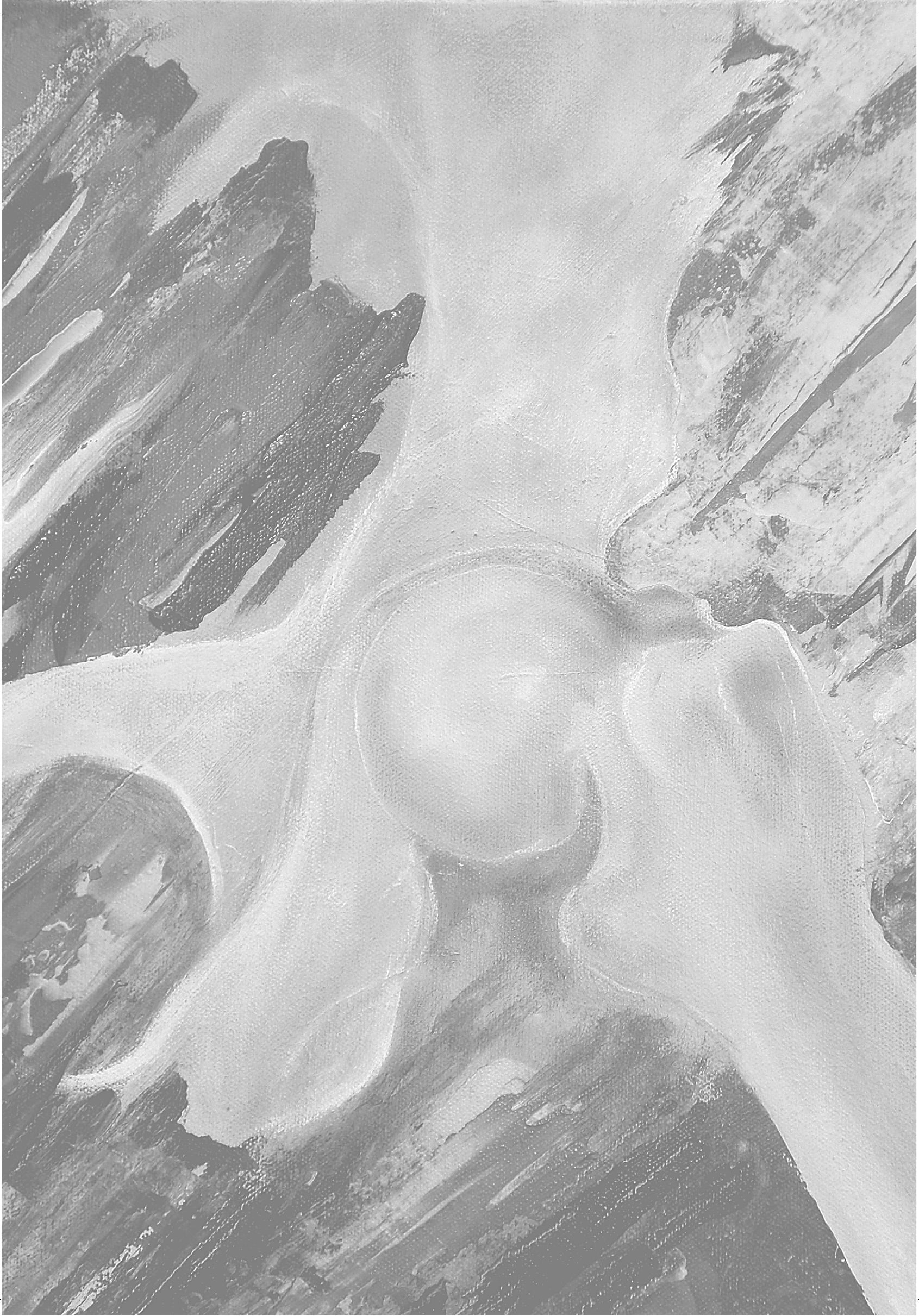




\section{Dankwoord}

N et veel plezier heb ik gewerkt aan het onderzoek dat beschreven is in dit proefschrift. Een proefschrift schrijven doe je nooit alleen en daarom wil ik op deze plaats graag iedereen bedanken die op een of andere manier een bijdrage heeft geleverd aan dit proefschrift. Een aantal personen zou ik graag nog bij name willen noemen.

Prof. dr. GJ Dinant, beste Geert-Jan, onze samenwerking begon al in 2004 toen ik in het kader van mijn opleiding Gezondheidswetenschappen mijn keuzeblokken binnen jouw onderzoek mocht uitvoeren. Deze stage is wederzijds zo goed bevallen dat daar mijn promotietraject uit is voortgevloeid. Jouw advies, vertrouwen, positieve feedback, tijd en hulp hebben ertoe geleid dat mijn promotietraject zeer soepel verlopen is. Bedankt dat ik altijd bij je kon aankloppen en voor de perfecte begeleiding.

Prof. dr. PP Geusens, beste Piet, uw kennis en ervaring, uw passie en aanstekelijk enthousiasme over het onderwerp hebben ervoor gezorgd dat ik steeds met goede moed en veel plezier doorging. Ik heb nog nooit iemand ontmoet met zoveel ideeën als $u$. $U$ geeft mij steeds het gevoel dat mijn onderzoek erg belangrijk is. Bedankt!

Dr. DJM van der Voort, beste Danny, zonder jou had ik nooit de beschikking gehad over zo'n fantastische dataset. Ruim 4000 vrouwen op baseline... wat een schat aan gegevens! Gelukkig wilde je ook meedoen aan het vervolgtraject. Ik kon altijd bij je terecht met vragen betreffende de baseline studie.

Natuurlijk wil ik ook Pauline Versteeg bedanken. Pauline, je bent zeer nauw betrokken geweest bij alle drie de fases van het onderzoek. Volgens mij ken je iedere huisarts, huisartsassistente en patiënt die mee heeft gedaan aan dit onderzoek persoonlijk. Je hebt een hele belangrijke rol gespeeld bij het zien van de patiënten en het invoeren van de data. Hartelijk dank!

Ik ben veel dank verschuldigd aan alle huisartsen en vrouwen die hebben meegewerkt aan dit onderzoek. Zonder jullie inzet was dit nooit mogelijk geweest. 
Vele co-auteurs hebben een bijdrage geleverd aan de verschillende hoofdstukken in dit proefschrift. Cyril Schreurs en Ivo Nagtzaam, bedankt voor het opzetten van de vervolgstudies en de samenwerking tijdens het eerste jaar. Svenjhalmar van Helden, ik heb het echt als een groot voordeel ervaren dat onze promotietrajecten naast elkaar liepen. Het uitwisselen van ideeën heeft mij echt geholpen. Alfons Kessels, dr. Arnold Kester, Paula Rinkens en dr. Bjorn Winkens bedank ik voor de statistische ondersteuning. Ook wil ik graag prof. dr. Peter Brink, prof. dr. Arie Nieuwenhuijzen Kruseman en dr. Jean-Pierre Sels bedanken voor het inbrengen van hun expertise.

De beoordelingscommissie bestaande uit prof. dr. Ruud Kempen, prof. dr. Onno van Schayck, prof. dr. Geert Walenkamp en dr. Petra Elders bedank ik voor de tijd die jullie hebben genomen voor het lezen en beoordelen van mijn manuscript.

Marika Burda, Janaica Grispen, Kim Luyten, Marion de Mooij, en Suzanne Koopmans wil ik bedanken. Bij jullie kwam ik geregeld als een wervelwind binnenstormen voor suggesties en jullie maakten er altijd tijd voor vrij. Janaica en Suzanne, bedankt dat jullie mijn paranimfen willen zijn.

Ook bedank ik dr. Rob Smeets. In het kader van mijn opleiding Gezondheidswetenschappen heb ik mijn afstudeeropdracht binnen jouw onderzoek uitgevoerd. Deze stage resulteerde in twee artikelen en heeft positief bijgedragen aan mijn schrijf- en statistische vaardigheden. Ondanks dat we niet meer direct samenwerkten, kon ik altijd op je terugvallen.

Erie van den Heuvel, Frits Ruijters en Ine Siegelaer bedank ik voor de administratieve hulp, Marga van der Aa en Jim Tatipata voor het oplossen van al mijn computercrisissen en Jan Klerkx voor het corrigeren van de tekst.

Ad van Geel bedank ik voor het ontwikkelen van de omslag. Ik ben blij dat je de klus op je hebt genomen. Het resultaat is fantastisch!

Tot slot bedank ik mijn ouders, broer en vriend voor hun rotsvaste vertrouwen. Jullie hebben als geen ander met mij meegeleefd. Bedankt voor het oppeppen en het mij laten geloven in mijn eigen kunnen. Zonder jullie steun was het nooit gelukt. 


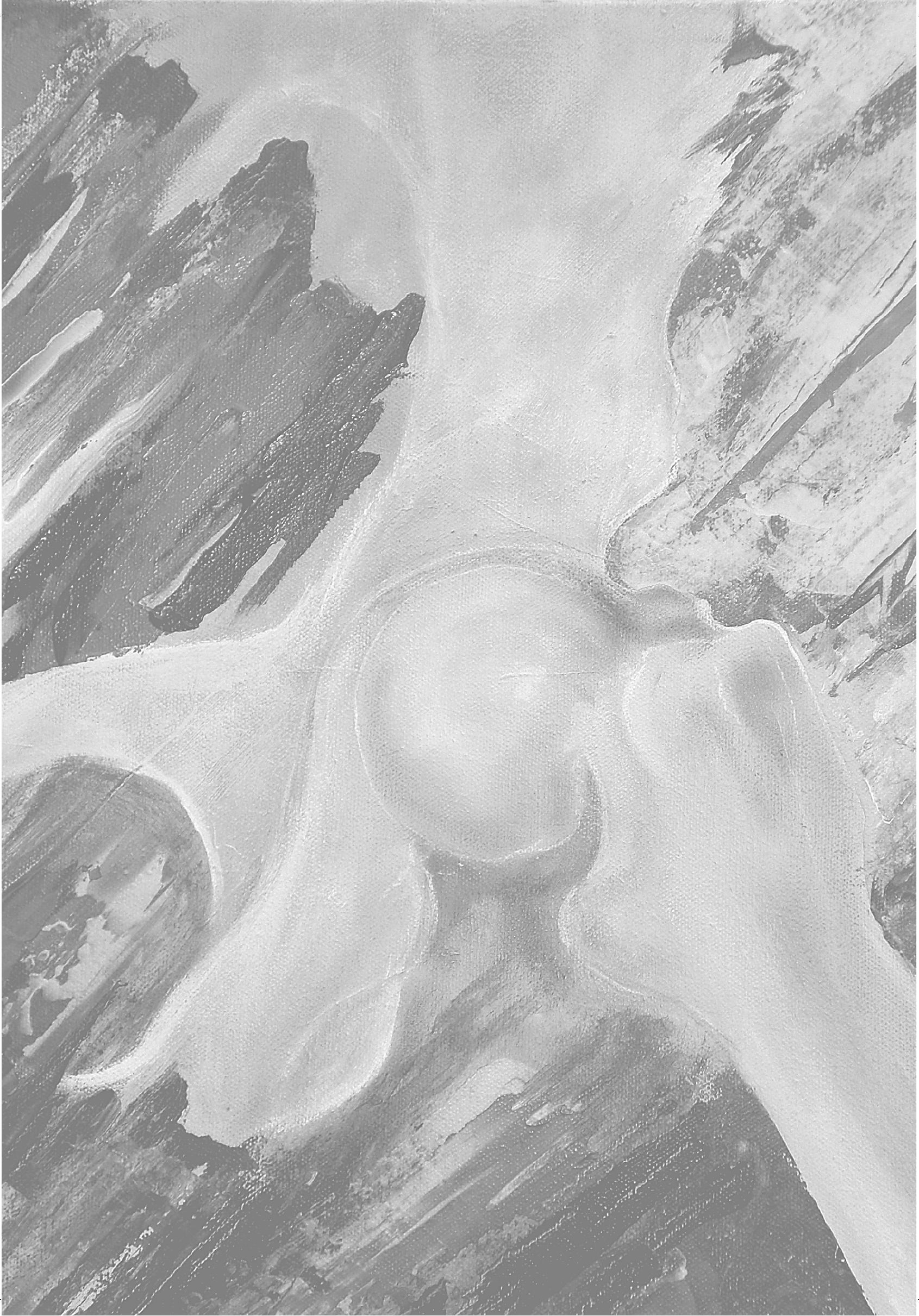




\section{About the author}

T ineke van Geel was born on the $11^{\text {th }}$ of November 1982 in Eersel, the school, at the Rythovius College in Eersel, and obtained her diploma (VWO) in 2001. She started Health Sciences training, major Movement Sciences, at Maastricht University and graduated as MSc in June 2005. From March 2004 until September 2004 she had a research rotationship at the Department of General Practice at Maastricht University. The research topic was 'the improvement of fracture prevention strategies in general practice - prognostic determinants of osteoporosis and (osteoporotic) fractures.' From September 2004 until August 2005 she had a research rotationship followed by a position as a research assistant at the Rehabilitation Center Blixembosch, Eindhoven. The research topic was 'active rehabilitation for chronic low back pain.'

The research of this dissertation was performed by the author as a PhD-student at the Department of General Practice at Maastricht University, and started in January 2006. From May 2008 she is appointed as a Kootstra Research Fellow for a year followed by an appointment as a postdoc-researcher at Maastricht University performing research on topics which are related to the research presented in this dissertation. 


\section{List of publications}

Tineke ACM van Geel, Svenhjalmar van Helden, Piet $P$ Geusens, Bjorn Winkens, Geert-Jan Dinant. Clinical subsequent fractures cluster in time after first fractures. Ann Rheum Dis. Published Online First: 03 August 2008. doi:10.1136/ard.2008.092775.

Piet Geusens, Bianca Dumitrescu, Tineke van Geel, Sven van Helden, Johan Vanhoof, Geert Jan Dinant. Impact of systematic implementation of a clinical case finding strategy on diagnosis and therapy of postmenopausal osteoporosis. J Bone Miner Res 2008; 23(6): 812-8.

Svenhjalmar van Helden, Antonia CM van Geel, Piet P Geusens, Evelien Pijpers, Gittie Willems, Alfons Kessels, Geert Jan Dinant, Rene ten Broeke, Arie Nieuwenhuijzen Kruseman, Peter RG Brink. Bone and fall-related fracture risks in women and men with a recent clinical fracture. J Bone Joint Surg 2008; 90: 241-8.

Tineke ACM van Geel, Piet P Geusens, Ivo F Nagtzaam, Danny JM van der Voort, Cyril MJR Schreurs, Paula ELM Rinkens, Geert-Jan Dinant. Risk factors for clinical fractures among postmenopausal women: a 10-year prospective study. Menopause International 2007; 13: 110-5.

RJEM Smeets, ACM van Geel, ADM Kester, JA Knottnerus. Physical capacity tasks in chronic low back pain: What is the contributing role of cardiovascular capacity, pain and psychological factors? Disabil Rehabil 2007; 29(7): 577-86.

Antonia CM van Geel, Piet P Geusens, Ivo F Nagtzaam, Cyril MJR Schreurs, Danny JM van der Voort, Paula ELM Rinkens, Arnold DM Kester, Geert-Jan Dinant. Timing and risk factors of clinical fractures among postmenopausal women: A 5-year prospective study. BMC Medicine 2006; 4 (24). doi: 10.1186/1741-7015-4-24

RJEM Smeets, JWS Vlaeyen, A Hidding, ADM Kester, GJMG van der Heijden, ACM van Geel, JA Knottnerus. Active rehabilitation for chronic low back pain: Cognitive-behavioral, physical, or both? First direct post-treatment results from a randomized controlled trial [ISRCTN22714229]. BMC Musculoskelet Disord. 2006; 7(1): 5 .

\section{Book chapter}

GJ Dinant, TACM van Geel. Het risico op osteoporose of een fractuur. In: GJ Dinant, MG Spigt, JA Knottnerus. Praktische epidemiologie. Maarssen: Elsevier Gezondheidszorg. 2008. 